Utah State University

DigitalCommons@USU

1914

\title{
Effects of Varying Certain Cooking Conditions in Producing Soda Pulp from Aspen
}

Henry E. Surface

Follow this and additional works at: https://digitalcommons.usu.edu/aspen_bib

Part of the Forest Sciences Commons

\section{Recommended Citation}

Surface, Henry E. 1914. Effects of varying certain cooking conditions in producing soda pulp from aspen. U.S. Department of Agriculture. Bulletin No. 80.

This Report is brought to you for free and open access by the Aspen Research at DigitalCommons@USU. It has been accepted for inclusion in Aspen Bibliography by an authorized administrator of DigitalCommons@USU. For more information, please contact

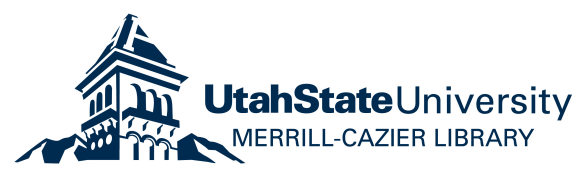




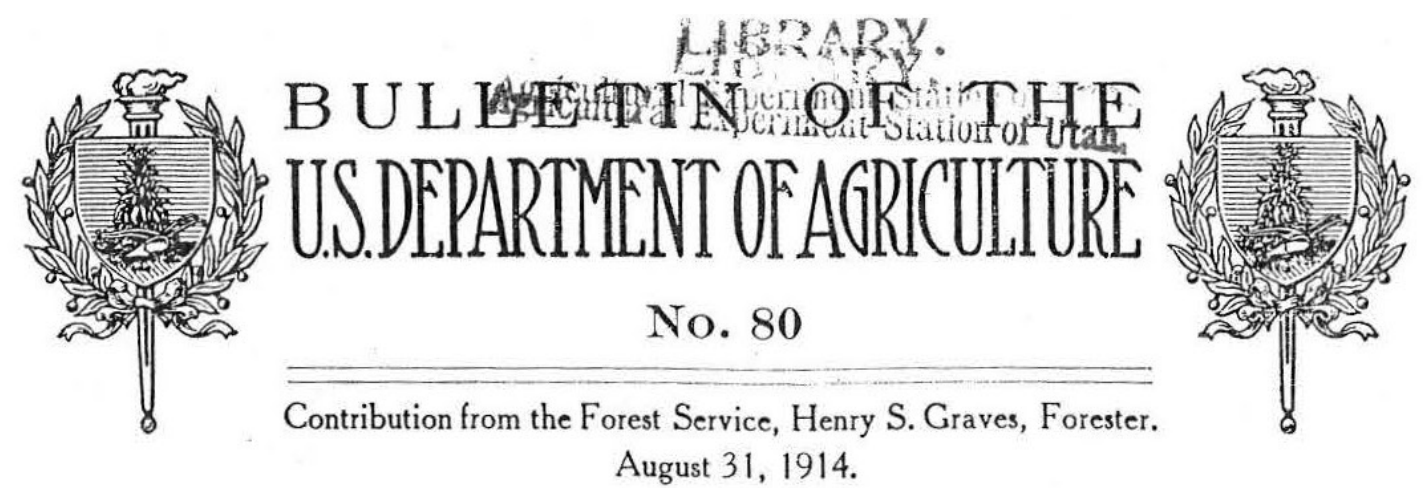

(PROFESSIONAL PAPER.)

\title{
EFFECTS OF VARYING CERTAIN COOKING CONDI- TIONS IN PRODUCING SODA PULP FROM ASPEN.'
}

\author{
By Henry E. Surface, \\ Engineer in Forest Products, Forest Products Laboratory.
}

PURPOSE OF EXPERIMENTS.

At the present time practically all of the soft, easy-bleaching pulps used for the manufacture of high-class book, magazine, general printing, and the cheaper writing papers are made by the soda process. In England such pulps are produced from esparto (alfa, or Spanish grass); in America, from the poplars and similar woods. Although the soda process of wood-pulp manufacture is not employed commercially to so great an extent in America as the sulphite and mechanical processes, it is remarkably well adapted for producing pulp fibers from any kind of wood or other fibrous vegetable material, no matter how resistant to chemical attack it may be. For this reason it is much used in the experimental work of the Forest Service.

To insure that a wood has been subjected to the most farorable cooking conditions it is necessary to cook it under many different conditions produced by varying such factors as the amount and concentration of the cooking chemical and the duration and temperature of cooking. While the general effect of using greater or less severity of cooking is well recognized in mill practice, there has been almost no available information on the quantitative effects of the individual factors concerned nor on the limitations within which such effects are exerted. Such meager information as may be found in the literature is widely scattered and is not strictly applicable to manufacturing conditions. Notwithstanding modern improvements and the general tendency toward more efficient operations in commercial plants, the most economical production apparently is not being attained by all of the soda-pulp mills. This is indicated by the fact that some of them are using from 10 to 20 per cent more pulp wood, from 50 to 100 per cent more chemicals, and from 10 to 40 per cent

1 This paper presents detailed information of value in experimental work in the laboratory and in promoting the efficiency of commercial paper-making plants employing the soda process.

$31091^{\circ}-$ Bull. $80-14-1$ 
more steam, and require much larger plants and more labor for the same tonnage output per day than others making similar products. I'v was to secure and make available detailed information which would both facilitate other experimental work in the laboratory and promote the efficiency of commercial plants employing the soda process that the series of tests discussed in this bulletin was undertaken. They were carried out at the Forest Products Laboratory maintained by the Forest Service at Madison, Wis., in cooperation with the University of Wisconsin.

The report of the experimental work is prefaced by a short description of the soda process and a review of previous investigations. Some general comments on aspen as a raw material for soda pulp and on the pulp itself will be found in the appendix, pages 41-47. This species of poplar was selected as the test material because it is the most important soda pulpwood. The information secured, however, is of much value also in connection with the cooking of other whel.

\section{THE SODA PROCESS AND ITS APPLICATION.}

What is here referred to as the soda process may be considered as a modification of the old Watt and Burgess process, first practiced in $1853,{ }^{1}$ and probably the oldest commercial method for producing chemical pulp from wood. It originally consisted in digesting suitably prepared wood in a large boiler with a strong solution of caustic soda under a pressure of about 90 pounds per square inch for 10 or 12 hours. The wood was then washed to remove the alkali and treated with chlorine gas or an oxygenous compound of chlorine. The partially digested wood was then washed to free it from the hydrochloric acid formed and again treated with a small quantity of caustic soda solution. The pulp so produced was then washed, bleached, and beaten in a beating engine, after which it was ready for the paper machine. The modification of this process as employed at the present time in the United States dispenses with the intermediate digestion treatment with chlorine compounds. Different cooking conditions also are used, the details of which, together with a brief description of the manner of preparing the wood, are given below.

\section{PREPARATION OF THE WOOD.}

While a few mills cook their wood unbarked or only partly barked, the general practice is to remove even the live inner bark. ${ }^{2}$ The

1 Charles Watt and Hugh Burgess secured a United States patent on this procesi in 1854. It was devel. oped further and modified by Juillon in France (1855), by Houghton in England (1857), and by Albert Ungerer, to whom a British patent was issued (1872). Further modifications gradually resulted from its commercial application.

2 The barking loss amounts to about one-fifth of the weight of unbarked logs. The losses in the case of logs from 31 trees used in these experiments varied from 16 to 20 per cent, which checks quite well with Ziegelmeyer's figure of 19.5 per cent on European aspen. (See Stevens, Paper Mill Chemist, p. 150, 1908.) A side from the convenience and ease of barking in the woods, the saving of freight is considerable when the wood is transported to the mills by railroad, and since the barked wood dries out rapidly an additional advantage is secured by the loss of weight in seasoning. $A$ cord of green aspen (about 50 per cent water) weighs about 1,900 pounds more than the same wood, air dry (about 15 per cent water). 
barked or peeled wood is then cut diagonally with the grain into slices or chips about one-half to three-fourths inch thick by means of a machine called a "chipper." These pieces are then further broken up by means of a disintegrator, or "shredder," and the resulting chips are conveyed to storage bins, usually above the digesters. An intermediate screening operation to remove dust and dirt and to secure uniform chips is sometimes given them.

On account of the strong solvent power of the cooking liquors used in the soda process it is not necessary to remove completely the knots or decayed portions of the wood. At some mills, however, the chips before being stored are sorted into different grades from which different qualities of pulp are produced. In the case of peeled wood, delivered as such to the mill, the outer shavings, if the wood is recleaned, are kept by themselves and converted into a lower-grade product. In some of the older mills the knots were removed from the peeled logs with a boring machine; and later the chips were picked over by hand. Such procedures, however, have now been practically abandoned in America.

\section{THE COOKING PROCEDURE.}

The digesters used in soda-pulp making are either rotary or stationary, and may be either cylindrical or spherical in shape. The present tendency in new installations is towards stationary, vertical, cylindrical digesters heated by live steam which enters at the bottom of the digester in such a manner as to carry the cooking liquor through a pipe to the top of the vessel and spray it over the chips. This insures good circulation. The chips and cooking liquors are charged through a manhole at the top of the digester, the bottom of which is provided with a "blow-off" pipe and valve for discharging the pulp after the cooking is complete. Such digesters are from 15 to 50 feet high by from 4 to 9 feet in diameter. The larger sizes have been lately introduced; in the past the most common size held about one cord of wood and was 16 feet high by 5 feet in diameter. At the time of the 1905 census the average American digester produced about 1 ton of pulp per cook, and the total combined capacity of the 208 soda digesters in operation then was 222 tons of pulp per cook.

As soon as the charging of chips and caustic soda cooking liquors is complete, steam is turned into the digester until a certain cooking pressure or temperature is reached. This temperature varies at different mills, but one corresponding to 110 pounds steam pressure per square inch is probably the most common at present. The pressure is continued from three to eight hours or more. ${ }^{1}$

WASHING OF PULPS AND RECOVERY OF COOKING CHEMICALS.

After the digestion process is completed the pulp in the digester is generally forced out under pressure or "blown" through a pipe

1 The detailed cooking conditions employed at various mills are shown in the appendix, Tables 16 and 17. 
connected with the bottom of the digester into " "blowpit" or "balloon;" whence it is transferred to large washing pans. Here it is drained as free as possible from the strong spent cooking liquors, called "black liquors," and washed thoroughly, first with hot, weak, black liquors from the last washings of previous cooks, and lastly with fresh hot water. The first drainings and washings which contain the greater part of the alkali cooking chemicals are run to evaporators, concentrated, and later calcined in furnaces. The burned ash, called "black ash," is leached with water, and the alkali in the form of sodium carbonate is dissolved. The resulting solution is treated with quicklime $(\mathrm{CaO})$, which changes the carbonate into caustic soda. Modern practice recovers from 88 to 92 per cent of the alkali charged into the digesters. By properly controlling the strength of the black ash solution and mixing various strengths of recausticized solutions, a caustic soda liquor of the desired strength for cooking is prepared. ${ }^{1}$

\section{TREATMENTS GIVEN THE SODA PULP.}

After the pulp has been thoroughly washed it is diluted with a large amount of water and screened to remove uncooked portions. This is accomplished by either flat plate, diaphragm screens, or by such screens in conjunction with centrifugal ones. In the case of aspen or poplar the greater proportion of the water in the pulp is then removed by means of "slushers," "feltless wet machines," or "deckers." The pulp is then treated in a suitable vessel with bleaching-powder solution and afterwards thoroughly washed. Very little aspen or poplar pulp is left in the unbleached state, but is usually bleached immediately after it is screened. Those mills making both pulp and paper generally carry the bleached wet pulp directly through the subsequent paper-making operations; but if the pulp is to be sold or stored it is simply run over a paper machine into rolls of dry pulp (about 10 per cent water).

\section{PREVIOUS INVESTIGATIONS.}

The treatises by Cross and Bevan ${ }^{2}$ and by Schwalbe ${ }^{3}$ and the recent experiments ${ }^{4}$ by Viewig, Miller-Moskan, Miller, Schwalbe, and Schwalbe and Robinoff give much information on the nature of the chemical reactions which take place between caustic soda and cellulose under various conditions, and on the formation of decomposition, mercerization, and other similar products from cellulose.

${ }^{1} \mathrm{~A}$ few mills still cling to the older practice of not recovering the alkali from the black liquors. Such mills buy the alkali for cooking in the form of caustic soda ( $\mathrm{NaOH})$. The cooking solution is produced by dissolving in water a sufficient quantity of the caustic to give a solution of the desired strength. The black liquors are run to waste, and, although the consumption of cooking chemicals is very high, the mills seem to operate at a profit.

2 Cellulose, 1903. Also Researches on Cellulose, 1895-1900; 1900-1905; 1905-1910.

${ }^{3}$ Die Chemie der Cellulose. 1910-1912.

4 For specific literature references see bibliography in appendix. 
While the manufacturer of paper pulp is interested in these chemical investigations they do not give him much practical information on the interrelation of the various cooking conditions which he employs and the effect of their modifications on the yield and quality of the pulp.

An article published by Tauss ${ }^{1}$ in 1889 , dealing with the effects of water alone on cellulose-containing materials, is of interest in connection with the Forest Service tests because the "yield" or residue with zero caustic soda assists in determining the curve for the effect of amount of caustic soda on the yield of crude pulp (fig. 4). Tauss's experiments showed (Table 1) that a very appreciable amount of solids can be extracted from wood and from cellulose by boiling in water, especially at high pressures. In 1890 the same author ${ }^{2}$ published the results of investigations in which caustic-soda solutions were employed in the place of water alone. The experiments with caustic soda were made partly with solutions of a concentration employed in commercial practice, partly with more concentrated, and partly with more dilute solutions. ${ }^{3}$ The calculated residues (Table 1) afford some interesting comparisons with the Forest Service yield data.

In 1907 De Cew ${ }^{4}$ published a technical article dealing with the function of the soda process in the production of wood cellulose. Although no data are cited to substantiate his conclusions, he makes the following statements:

The results obtained with this process depend very largely upon the accuracy with which it is carried out. The action of caustic soda is one of hydrolysis, in which the woody molecule is gradually broken down with the formation of acid products which combine with and neutralize the alkali, leaving the cellulose in the form of isolated fibers. Now, if sufficient alkali were used and the cooking action continued, the entire fiber would finally be dissolved, although the more resistant celluloses would be the last to disappear. It is, therefore, necessary in order to bring into solution only the lignified portion of the wood to add just sufficient alkali for this purpose.

This is almost entirely neutralized by the acid products formed from the lignocellulose, and thus very little free alkali is left in the liquor to attack the rest of the fiber, which should be almost pure cellulose. At first the alkali is very active and a rapid combination takes place, but the rate of reaction becomes continually slower as the free alkali grows less and the resistance increases. There are also such varying conditions as to causticity, pressure, circulation, and time of cooking, which are of considerable importance in the process, for some makers are obtaining from 1-200 pounds of fiber per cord more than others in treating the same kind of wood.

${ }^{1}$ Dingl. Polyt. J., pp. 276-285, vol. 273, 1889; Jour. Soc. Chem. Ind., p. 913, vol. 8, 1889.

2 Ibid., pp. 411-428, vol. 276, 1890; Jr. Soc. Chem. Ind., p. 883, vol. 9, 1890.

3 See footnote, p. 16.

4 Jour. Soc. Chem. Ind., pp. 561-563, vol. 26, 1907; Chemical A bstracts, p. 319, 1908. 


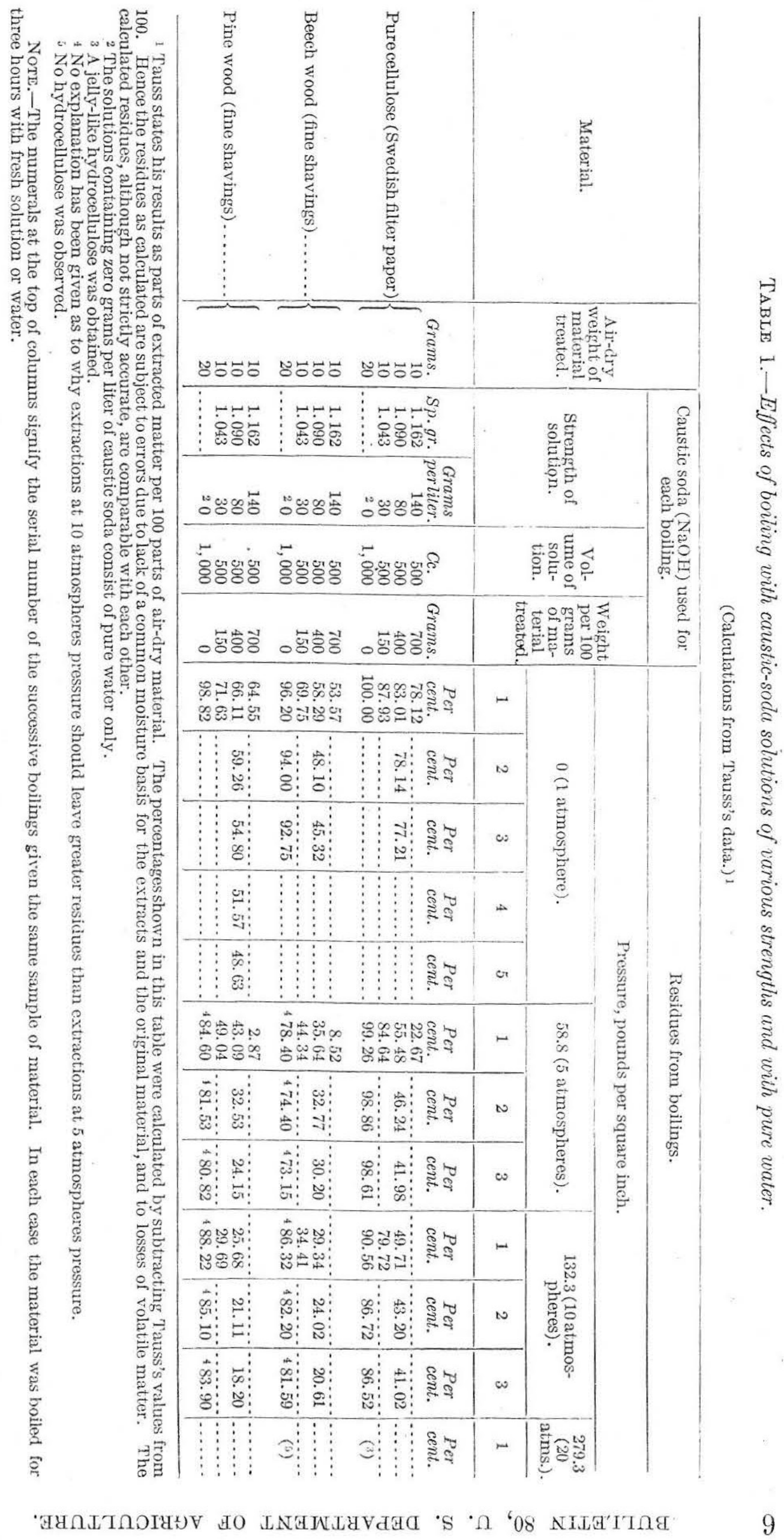


In regard to the time required for cooking there is a wide difference in practice. However, the most improved plants are now able to effect the complete resolution of the wood in a very short time. In fact, any of the deciduous woods can now be reduced in about four hours. With the improvements in the methods of cooking that have been developed, which enable us to get about twice the work out of a digester that was formerly obtained, a number of special advantages have been found to be the result of these quick cooks. The shorter the time the alkali is in contact with the cellulose, the higher is the yield obtained and the sounder and stronger is the fiber. If all of the cellulose is freed from the lignin at practically the same time, the free alkali will have very little time to react on the weaker celluloses and the fibers will not be broken nor the points and serrations dissolved. Moreover, the fibers from the short cook are not hard to bleach, because the character of the cellulose is uniform. Under conditions of complete saturation with the right proportion of alkali, the lignocelluloses can be almost instantly dissolved by subjecting the material to the temperature and pressure that is ordinarily used for cooking the fiber. The writer has performed this experiment on a laboratory scale, and the fiber obtained so closely resembled the actual structure of the woody cell that hardly any cellulose could have been dissolved.

Clapperton, ${ }^{1}$ in 1907 , in writing about the soda process, says:

It is the necessity for employing such high temperatures and pressures (90 pounds per square inch) that constitutes the serious drawback to the alkali process as under the conditions of boiling the strong caustic soda acts on the cellulose, impairing the strength and reducing the yield. ${ }^{2}$ The reason why such conditions are necessary is that the soluble acid bodies resolved by the caustic become so oxidized and condensed that they counteract and weaken the reducing action of the soda, and in order to equalize their resistance higher temperatures and pressures have to be employed.

Beveridge ${ }^{3}$ recently published the results of some of his experiments on the effects of varying the cooking conditions in the production of esparto pulp. He says:

The treatment of esparto by the soda method is typical of the preparation of paper pulp from nearly all fiber-yielding plants, such as bamboo, straw, wood, etc. The isolation of cellulose is brought about by digesting the prepared plant in an alkaline solution, having for its base caustic soda, at variable temperatures and under variable lengths of time. The chemical reaction which takes place during this digesting process is not known; that is to say, has not been isolated because of the complicated character of the encrusting substances surrounding the fiber in the plant. The caustic soda in aqueous solution forms soluble compounds with these encrusting bodies and dissolves any silica which forms a part of the plant's structure, so that by subsequent draining, washing, and bleaching the liberated cellulose is obtained in a comparatively pure state. Cellulose from whatever source it is obtained is, however, soluble in aqueous solutions of caustic soda. Moreover, the solvent action of the caustic is accelerated by heat and by the length of time (within limits) in which the two bodies are heated together. It is therefore apparent that if the maximum yield of cellulose is desired when using this method due regard must be paid to the laws regulating the yield. These laws may be expressed thus: The yield of cellulose obtained from any plant by the caustic-soda method depends upon:

(1) The proportion of caustic soda $(\mathrm{NaOH})$ used per unit weight of plant;

(2) The temperature employed; and

(3) The length of time the digesting operation is continued.

\footnotetext{
1 Practical Papermaking, p. 33, 2d ed., 1907.

2 In modern commercial practice even higher temperatures and pressures are employed, and the results of the Forest Service tests do not corroborate Clapperton's statements as to the undesirable effects from using them.

${ }^{3}$ Papermaker's Pocketbook, p. 72, 2d ed., 1911. See also Sindall, Manufacture of Paper, p. 77, 1908.
} 
If any one of these conditions be altered and the other two kept constant, the yield varies inversely as the altered condition. Thus, in the case of esparto, the author performed a series of experiments in which the proportion of caustic to unit weight of esparto was varied, whilst the temperature and duration of time of digesting were both kept constant with the following results (Table 2).

TABLE 2.-Experiments regarding yield of air-dry bleached pulp from Oran esparto.

\begin{tabular}{|c|c|c|c|c|c|c|c|c|c|}
\hline \multirow{2}{*}{$\begin{array}{l}\text { No. of ex- } \\
\text { periment. }\end{array}$} & \multirow{2}{*}{$\begin{array}{l}\text { Esparto, } \\
\text { weight } \\
\text { taken. }\end{array}$} & \multicolumn{2}{|c|}{ Soda liquor. } & \multicolumn{3}{|c|}{ Conditions of boiling. } & \multirow{2}{*}{$\begin{array}{c}\text { Weight of } \\
\text { air-dry } \\
\text { pulp. }\end{array}$} & \multirow{2}{*}{$\begin{array}{l}\text { Dry pulp } \\
\text { on dry } \\
\text { esparto. }\end{array}$} & \multirow{2}{*}{$\begin{array}{l}\text { Bleaching } \\
\text { powder. }\end{array}$} \\
\hline & & Volume. & $\mathrm{Na}_{2} \mathrm{O}$. & Time. & $\begin{array}{l}\text { Tempera- } \\
\text { ture. }\end{array}$ & Pressure. & & & \\
\hline $\begin{array}{l}1 \ldots \ldots \ldots \\
2 \ldots \ldots \ldots \\
3 \ldots \ldots \\
\end{array}$ & $\begin{array}{r}\text { Grams. } \\
200 \\
200 \\
200\end{array}$ & $\begin{array}{l}\text { Cc. } \\
800 \\
800 \\
800\end{array}$ & $\begin{array}{r}\text { Percent. } \\
1.58 \\
2.13 \\
2.69\end{array}$ & $\begin{array}{r}\text { Hours. } \\
3 \\
3 \\
3\end{array}$ & $\begin{array}{r}{ }^{\circ} \mathrm{C} \\
142 \\
142 \\
142\end{array}$ & $\begin{array}{r}\text { Lbs. } \\
55 \\
55 \\
55\end{array}$ & $\begin{array}{r}\text { Grams. } \\
87.30 \\
80.67 \\
72.00\end{array}$ & $\begin{array}{r}\text { Per cent. } \\
43.91 \\
40.55 \\
36.20\end{array}$ & $\begin{array}{r}\text { Per cent. } \\
29.5 \\
18.5 \\
10.5\end{array}$ \\
\hline
\end{tabular}

NoTE.-The different trials were made in wrought-iron tubes fitted with screw caps, all three being heated together in an oil bath for three hours at a temperature of $302^{\circ} \mathrm{F}$. (55 pounds above atmosphere).

The following is taken direct from Cross, Bevan, and Sindall's ${ }^{1}$ résumé of Beveridge's experimental results, which include the data quoted in Table 2 and others:

He made three sets of trials, as follows:

Constant conditions.

1. Time and strength of caustic.

2. Pressure and time.

3. Pressure and strength of caustic.

The results were:

1. Increase of pressure resulted in a diminution of yield, the quantity of pulp obtained being reduced considerably.

2. Excess of caustic soda caused rapid diminution in the yield of cellulose.

3. Gradual exhaustion of the caustic soda by prolonged digestion prevented such serious diminution of yield.

The discussions and experimental results which have been quoted show in a general way the effects of varying some of the fundamental cooking conditions in the soda process. None of the experiments cited are directly comparable to commercial practice in this country, because the testing conditions were not sufficiently representative of manufacturing conditions, and, in the case of Beveridge's experiments, because esparto-a grass, or pectocellulose-was used as the test material. Moreover, the effects of the cooking conditions employed were not studied in as great detail as seemed desirable. The experiments show very clearly, however, that improper cooking conditions are wasteful or inefficient, and indicate the need for complete experimental data on which improvements in commercial practice may be based. 


\section{METHOD OF CONDUCTING EXPERIMENTS.}

SCOPE AND PLAN OF TESTS.

Aside from the character of a wood or other material prepared for cooking, the principal cooking conditions affecting yields and properties of pulps, consumption of cooking chemicals, and the general efficiency and costs of the cooking operations are indicated under the following general headings:

(1) Preliminary treatments which may in some cases be given the prepared chips. This includes such treatments as preliminary pressure, vacuum, or steaming.

(2) Character of the cooking apparatus, including size, shape, and construction of the digester; manner of heating, whether by saturated or superheated steam turned directly into the digester, or by the use of steam jackets or flue gases; also the degree and kind of mechanical agitation employed, if any.

(3) Proportions of the charges. This covers the amounts of wood and chemicals; also the amounts of water present in the wood and the original cooking solutions together with the water condensing in the charges from steam used in cooking.

(4) Character of the cooking liquors when charged. Such items as causticity, initial temperature, impurities, and concentration are important.

(5) Duration of the cooking treatment. The treatment is in three periods-(a) a period of increasing temperature; $(b)$ a period at maximum temperature; and $(c)$ in some cases, a period of decreasing temperature.

(6) Pressures and temperatures. This considers the pressures and temperatures of the digester contents at different stages of cooking; also the temperature of the digester room (as affecting radiation and condensation).

(7) Manner of admitting steam, "relieving," and "blowing" the digester.

Since the effects of the variable cooking conditions may be modified by the treatments given the pulps after leaving the digestersuch as leaching or washing, screening and bleaching-these treatments must also be taken into account, for it is not possible to determine all the important effects of the cooking treatments until the finished pulps have been prepared.

The many factors are more or less interdependent, and any change in one results in unavoidable changes in others. Four of the more fundamental of these factors have been investigated in the Forest Service experiments. They are:

(1) Amount of caustic soda charged per pound of wood.

(2) Duration of cooking at maximum temperature.

(3) Maximum temperature (pressure) of cooking.

(4) Initial concentration of the cooking chemicals.

The effect of these four factors upon the yield and properties of the pulp and the consumption of cooking chemicals were determined. ${ }^{1}$

- 1 The purely chemical aspect of the cooking action has not been given special consideration. The effect of the caustic soda cooking liquors under the conditions employed in pulp making is recognized as a hydrolytic action in which the caustic soda extends the limits of hydrolysis. This subject has been given careful attention by Cross and Bevan, Schwalbe, De Cew, and others as indicated in previousreferences. The effects of the cooking conditions on the recovery of soda also have been given no consideration except in a very cursory manner. The laboratory facilities did not permit this important subject to be studied at the time of the experiments. 
The tests fall naturally into four groups; in each group all the conditions were held as nearly constant as possible except the factor under investigation, which was raried in successive tests or "cooks" according to a definite plan. The plan of the tests is shown in Table 3. In addition to the factors mentioned in this table all other factors under control were so far as possible held constant. Those for which values were specified are the following:

Amount of chips for each charge, 40 pounds bone-dry weight.

Dryness of chips, air dry.

Causticity of cooking liquors, $95-98$ per cent.

Temperature of charging cooking liquor, $22^{\circ} \mathrm{C}$. $\left(72^{\circ} \mathrm{F}\right.$.)

Temperature of digester room, $22^{\circ} \mathrm{C} .\left(72^{\circ} \mathrm{F}\right.$.)

Duration of cooking before maximum pressure is reached, 1 hour.

Duration of cooling and relieving digester before blowing, 5-10 minutes.

Blowing pressure, 30 pounds per square inch.

TABLE 3.-Plan of cooking experiments.

\begin{tabular}{|c|c|c|c|c|c|}
\hline \multirow[b]{2}{*}{$\begin{array}{l}\text { Test } \\
\text { group. }\end{array}$} & \multirow[b]{2}{*}{$\begin{array}{l}\text { Numi- } \\
\text { ber of } \\
\text { tests. }\end{array}$} & \multicolumn{4}{|c|}{ Cooking conditions under investigation. } \\
\hline & & $\begin{array}{l}\text { Initial concentration } \\
\text { of caustic soda in } \\
\text { digester liquors. }\end{array}$ & $\begin{array}{l}\text { Amount of caustic } \\
\text { sod a p e r } 100 \\
\text { pounds of wood.1 }\end{array}$ & $\begin{array}{l}\text { Maximum cooking } \\
\text { temper a ture } \\
\text { (equivalent steam } \\
\text { pressure). }\end{array}$ & $\begin{array}{l}\text { Duration of cooking } \\
\text { at maximum pres- } \\
\text { sure or tempera- } \\
\text { ture. }\end{array}$ \\
\hline I. & 6 & $\begin{array}{l}\text { Constant-80 grams } \\
\text { per liter. }\end{array}$ & $\begin{array}{l}\text { Variable-from } 15 \\
\text { to } 40 \text { pounds in } \\
\text { steps of } 5 \text { pounds } \\
\text { each. }\end{array}$ & $\begin{array}{l}\text { Constant-100 } \\
\text { pounds per square } \\
\text { inch. }\end{array}$ & Constant-6 hours. \\
\hline II. & 6 & Same as Group I.... & $\begin{array}{l}\text { Constant-25 pounds } \\
\text { (value selected } \\
\text { from Group I tests } \\
\text { as most satisfac- }\end{array}$ & Same as Group I.... & $\begin{array}{l}\text { Variable-from } 1 \text { to } \\
11 \text { hours in steps } \\
\text { of } 2 \text { hours each. }\end{array}$ \\
\hline III. & 6 & r. & $\begin{array}{l}\text { tory for later tests). } \\
\text { Same as Group II... }\end{array}$ & $\begin{array}{l}\text { Variable-from } 70 \text { to } \\
120 \text { pounds per } \\
\text { square inch in } \\
\text { steps of } 10 \text { pounds } \\
\text { each. }\end{array}$ & $\begin{array}{cr}\text { Constant-7 } & \text { hours } \\
\text { (value } & \text { selected } \\
\text { from Group II tests } \\
\text { as most satisfac- } \\
\text { tory for later tests). }\end{array}$ \\
\hline IV. & 4 & $\begin{array}{l}\text { Variable-from } 110 \\
\text { to } 50 \text { grams per } \\
\text { liter in steps of } 20 \\
\text { grams each. }\end{array}$ & $\ldots$. do $\ldots$ & $\begin{array}{l}\text { Cons t a n t-1 } 000 \\
\text { pounds per square } \\
\text { inch (value se- } \\
\text { lected from Group } \\
\text { III tests as most } \\
\text { satisfactory for } \\
\text { later tests). }\end{array}$ & Same as Group III. \\
\hline
\end{tabular}

IIn commercial practice it is customary to vary the amount of chemical used and its initial concentration both at the same time when attempting to change the severity of the cooking due to these factors. This results in the volume of the cooking liquors being kept approximately the same, which is a desirable feature. In these tests, however, it was the intention to find out the effects of each factor separately.

TESTING PROCEDURE.

The apparatus employed in cooking is shown in figure 1. Figure 2 shows diagrammatically the course of the material through the various stages of treatment and testing, and in this way the relation of one part of the procedure to another is made clear.

After the amount of moisture in the chips had been ascertained by means of sample $A$, the charge was weighed out and put into the digester. Caustic soda solution, of the desired concentration and volume, had been prepared by diluting the necessary quantity of analyzed stock solution (sample B) with water. It was then heated 
to the charging temperature and run into the digester, and the cooking operation was begun by permitting live steam to enter at the bottom.

During the cooking, observations were made at 15 -minute intervals of (1) digester temperature, (2) digester pressure, (3) steam pressure at digester inlet, and (4) room temperature. The volume of liquor

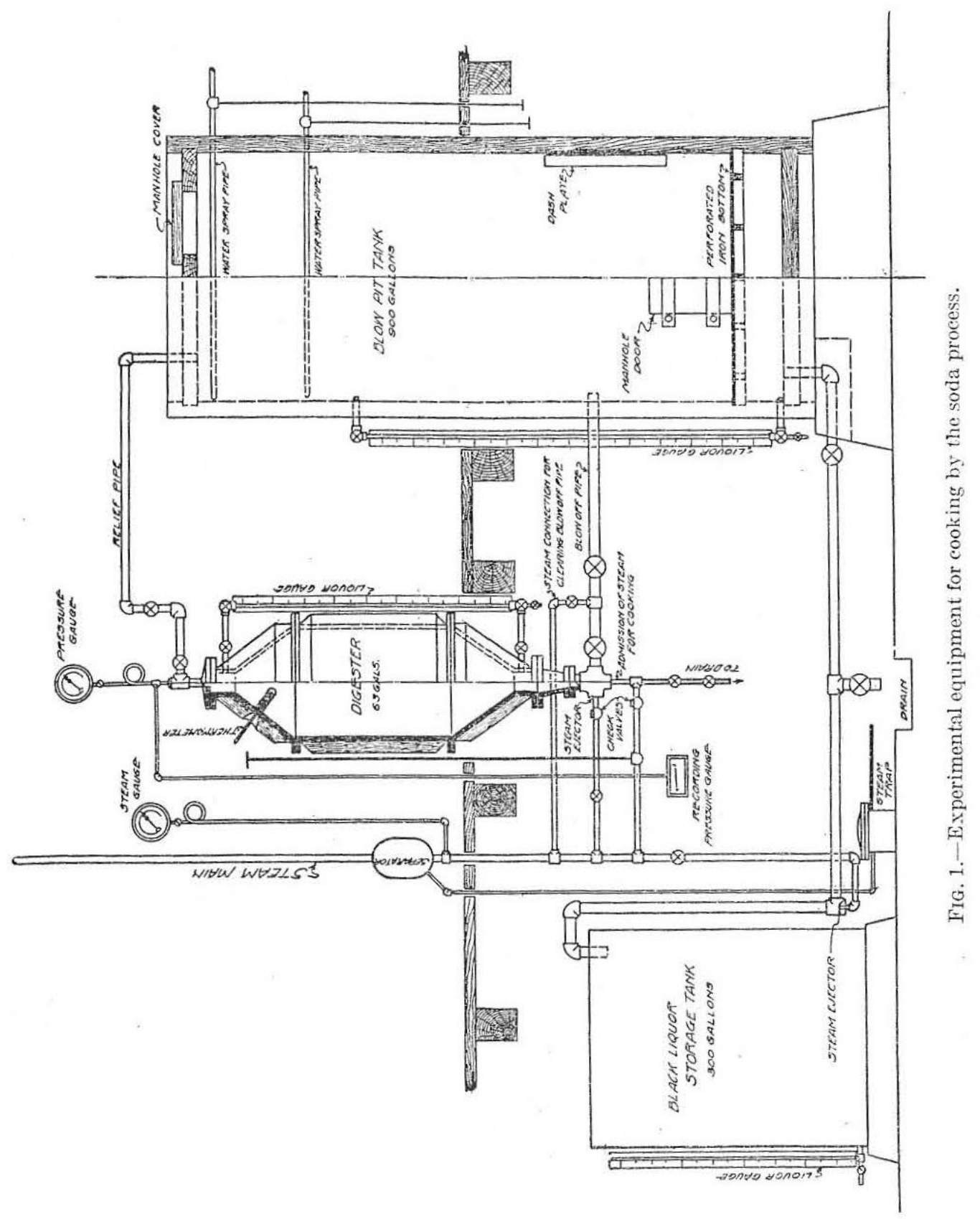

in the digester was also observed, but at hourly intervals. These observations were recorded, and a graphic "log of cook" was made at the same time, an example of which is shown in figure 3 . If at any time the digester temperatures and pressures as observed on the thermometer and pressure gauge did not agree when compared by means of pressure-temperature tables for saturated steam, the excess of pressure was relieved; such a condition occurred as a rule only dur- 
ing the first hour of cooking. The room temperature and the pressure of steam at digester inlet were kept as near constant as possible for all the tests, so that all conditions affecting condensation, aside from the cooking operation itself, would be uniform. For the same

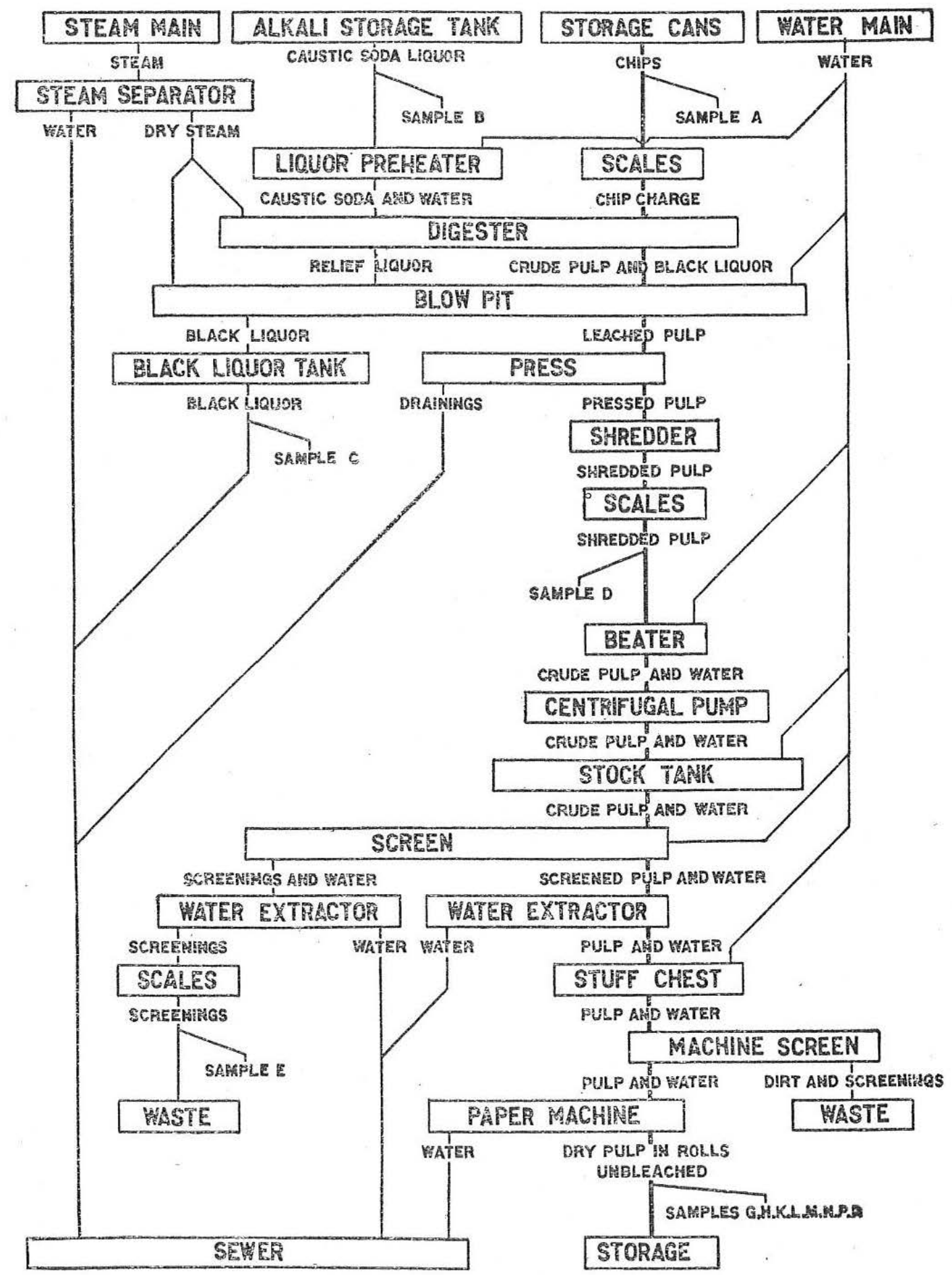

Fig. 2.--Flow sheet, showing course of material through the various stages of treatment and testing.

reason, steam of approximately the same moisture content was used in all tests.

During the first hour of cooking the digester pressure and temperature were brought, at a uniform rate, up to the maximum to be 
employed, and were held constant at this value during the remainder of the cook. At the end of the cooking period the top relief vent was opened and the digester pressure quickly "relieved" until "blowing pressure" was reached, when the vent was closed, the two blow-off valves were opened, and the digester was emptied under blowing pressure with the assistance of a steam ejector in the blow-off line.

The pulp was caught in the blow pit, where it was washed with three or more 50-gallon applications of hot water. After the blowing and after each successive washing the pulp was allowed to drain, and the drainings were pumped to the black-liquor storage tank. The washing operations were continued until the last drainings were of a specific gravity lower than 1.003 at $22^{\circ} \mathrm{C}$. Inasmuch as the top relief pipe emptied into the blow pit, it was possible to collect the small amount of relief liquors, together with the black liquors, in the storage tank, where the volume of the whole was read off on the graduated tank gauge. A sample of this

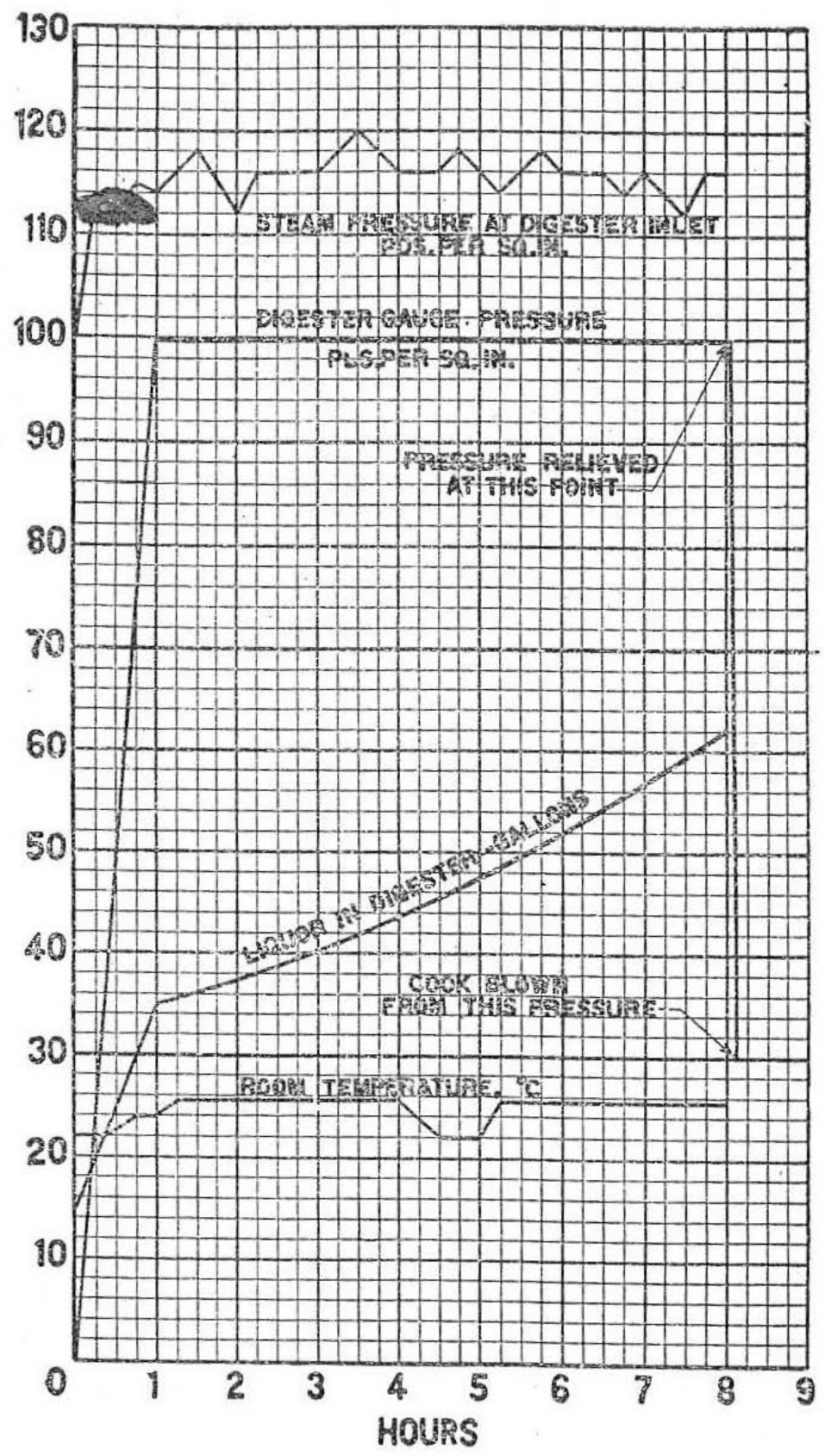

FIG. 3.--Typical graphic log of cook. (Cook 24.) (sample C) was secured for analysis, and the amount and character of the recovered chemicals determined. (Fig. 2.)

After the last washing the crude pulp in the blow pit was drained as dry as possible and, by means of scoops, removed to a strong linen bag inclosed in a perforated metal cylinder. The pulp in this form was then placed under a 70-ton, knuckle-joint, power press. After being pressed to about 30 per cent bone dry the pulp was next 
"opened up" in a swing-hammer shredder running at low speed and without a cage, so that the largest lumps after shredding were about hazelnut size. This was done to facilitate sampling and increase the accuracy of the dry-weight determinations. The shredded pulp was weighed and sampled (sample D) for determining the dry weight. It was then mixed with water and further opened up in a 25-pound Hollander-style beater, with the roll well off the bedplate so that no real beating could take place, and was pumped from the beater to a 200-gallon stock tank at the head of the screening system, where it was diluted with water to a known volume. This mixture was then screened by means of a 6-plate diaphragm screen with slots 0.009 inch wide. The screenings which went over the plates were then collected, weighed, and sampled (sample E), as described for the crude pulp. The screened, unbleached pulp which went through the screen slots, mixed with a large amount of water, was run to a water extractor and concentrated. Afterwards it was pumped to the paper machine stuff chest, made up to a known volume with water, pumped to the machine screen (diaphragm type, 0.012 inch slots), and run out on a 15-inch Fourdrinier paper machine (see Pl. I), into a sheet 10 inches wide by about 0.010-0.011 inch thick. The rolls of the screened, unbleached pulp thus secured were stored awaiting the tests to determine its properties for which samples $G$ to $R$ were taken. Where the screenings were so large in amount as to preclude accuracy of sampling the crude unscreened pulp, such pulp was screened without the preliminary pressing, shredding, etc., and the screened pulp was collected on a 70-mesh sieve, pressed, shredded, weighed, and sampled for the yield determinations. The pulp was then screened again and made up into a sheet as described.

The methods used for determining dry weights, yields, quality of pulps, and composition of liquors are given in the appendix.

\section{TEST MATERIALS USED.}

WOOD.

The test material consisted of 31 logs of aspen (Populus tremuloides, Michx.) cut from representative trees growing intermixed with white birch near Rhinelander, Wis. The trees were of seed growth and had attained an average height of 44 feet, with straight, clear lengths of about 22 feet from whicn the logs were cut.

The ages of the logs varied from 28 to 42 years, as determined by counting the annual rings. The logs were fairly free from knots, considering the size of the trees and the species. Volume-weight determinations on 36 samples, representative of the whole shipment, showed the average bone-dry weight per cubic foot of green or 
unseasoned wood free from knots to be 26.68 pounds. The samples ranged from 23.6 to 31.4 pounds per cubic foot.

As a rule the test material was sound, but some of the logs had decayed hearts. The material was peeled by means of a carpenter's drawknife; all decayed portions on the outside of the pieces and all protruding knots were chopped off. This cleaned wood was then sawed into disks five-eighths inch thick in the direction of the grain. Butts, tops, and all disks containing decay or other defects were culled.

The remaining sound disks were split with the grain into chips 1 inch to 6 inches by one-fourth inch by means of a special guillotine chipping machine. All knots were culled. The chips were then seasoned to constant air-dry weight, thoroughly mixed and screened to remove sawdust and dirt, and finally stored in cans to await the cooking tests.

\section{COOKING CHEMICALS AND SOLUTIONS.}

In ordinary mill practice the soda cooking liquors are made as described on page 4. The freshly causticized solution contains caustic soda $(\mathrm{NaOH})$ for the most part, but a small amount of soda ash (sodium carbonate, $\mathrm{Na}_{2} \mathrm{CO}_{3}$ ) still remains uncausticized. Various impurities are also present, but these are considered to have no effect in cooking.

In the experiments the cooking solutions were made by dissolving fused caustic soda, 76 per cent ${ }^{1}$ sodium oxide $\left(\mathrm{Na}_{2} \mathrm{O}\right)$, in water. The resulting solution was similar to the solutions used in commercial practice so far as caustic soda and soda ash are concerned, and there is no reason to believe that the results should be different in any way from those which would have been obtained by the use of commercial liquors of the same concentration and causticity.

\section{EFFECTS OF VARIATIONS IN THE COOKING CONDITIONS.}

The influence of the variable cooking condition in each group of tests on resultant yields and properties of pulps and consumption of cooking chemicals is shown graphically in figures 4 to $15 .^{2}$ The same results in greater detail are given in Tables 10 to 14 of the appendix. While, in general, the tests were carried out in accordance with the plan which has been described, minor departures could not be avoided, and the location of certain points on the diagrams are more or less affected by such variations. For this reason the tabulated data should be consulted for the exact conditions of each cook.

1 Manufacturer's analysis.

2 The numerals opposite each platted point on the curves are the serial numbers of the cooks. (See Tables 10 to 14.) 
YIELDS.

The effects on yields of pulp and screenings are expressed by the curves in figure 4 , in which the yields are plotted against the amount of caustic soda, the duration of cooking, the pressure of cooking, and the initial concentration of caustic soda.

\section{AMOUNT OF CAUSTIC SODA.}

With increases in the amount of caustic soda per pound of wood the yield of total crude pulp decreased at the rate of about 1 per cent for each 2 per cent of caustic (0.02 pound $\mathrm{NaOH}$ per pound of
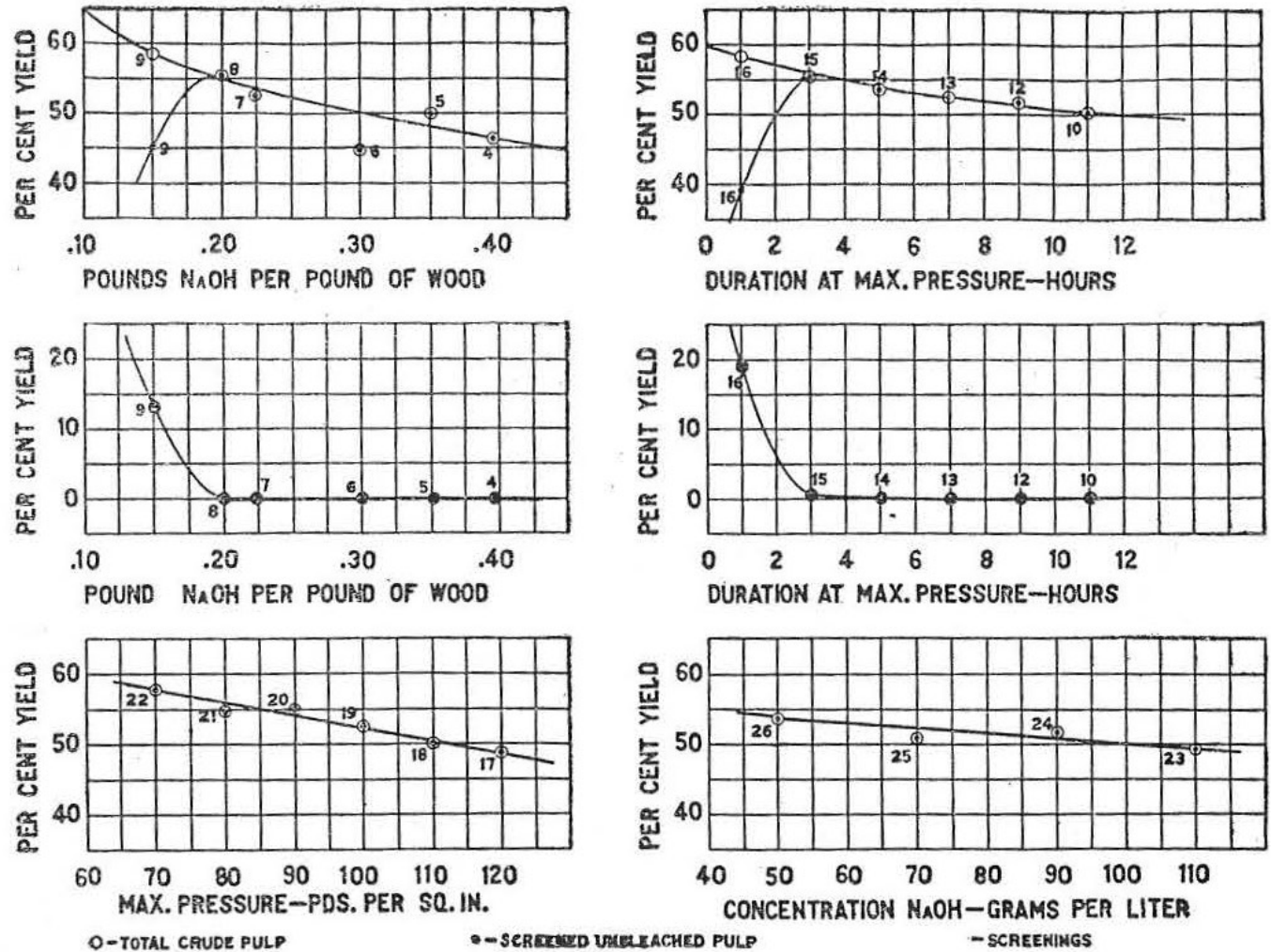

FIG. 4.-Effects of cooking conditions on yields of total crude pulp, screened unbleached pulp, and screenings.

wood). The yield at zero caustic soda would probably fall between 80 and 90 per cent, being influenced only by the cooking effect ${ }^{1}$ of the water condensed from the steam used in cooking. For high amounts of caustic soda the curve tends to approach parallelism with the horizontal axis. The yield would not be expected to become zero unless exceedingly large amounts of caustic were used. ${ }^{2}$

For amounts of caustic soda above what may be considered the minimum for successful cooking under the conditions used, the yield

1 See Tauss's experiments, Table 1.

2 Tauss used for a single boiling as high as 7 pounds of caustic soda per pound of wood, and the yield or undissolved material after three hours at 58.8 pounds per square inch steam pressure amounted to 8.52 per cent for beech and 2.87 per cent for pine. With 4 pounds caustic soda per pound of wood in each of three successive three-hour treatments under a steam pressure of 132.3 pounds per square inch, the yields for the two woods were 20.61 per cent and 18.20 per cent, respectively. This latter proportion of caustic soda was ten or more times as great as is ordinarily employed in commercial practice. Aiso the other cooking conditions were proportionately more severe. 


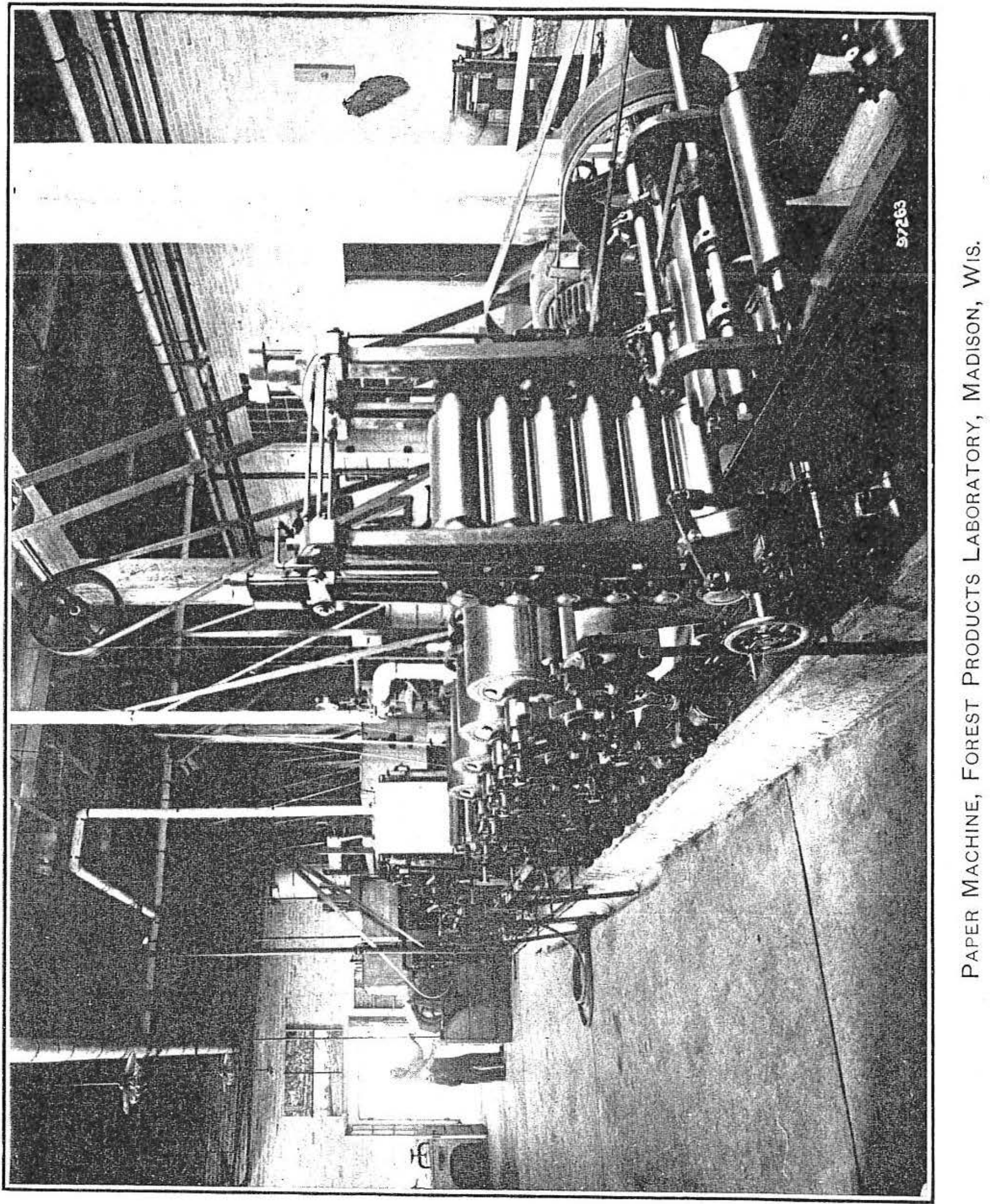


of screened unbleached pulp was identical with that of crude pulp, but for smaller amounts of chemical it rapidly approached zero, while under the same conditions the screenings curve naturally approaches and becomes coincident with the curve for the total crude pulp. In this group of tests the minimum amount of caustic soda for successful cooking, so far as yields alone are concerned, is somewhere between 15 and 20 per cent.

DURATION OF COOKING.

The duration of cooking at maximum pressure influenced the yields in very much the same manner as did the amount of chemical. The yield of total crude pulp decreased about 1 per cent for each additional hour of cooking at maximum pressure. However, the curve (fig. 4) seems to approach parallelism with the horizontal axis, thus signifying that beyond a certain point cooking would have had no further effect. ${ }^{1}$ The time allowed for these cooks to reach the maximum pressure was one hour, and the extended curve indicates a yield of about 60 per cent for zero hours duration at maximum pressure. This shows that the greater part of the cooking was accomplished during the first hour, or before the maximum pressure was attained, since during that hour about 40 per cent of the wood substance had been dissolved and the dissolving effect during the next 12 hours was only one-fourth as great.

As determined by the yield curves, the minimum duration for successful cooking under the conditions employed was between one and three hours at maximum pressure. No tests were made between these two points.

PRESSURE OF COOKING.

The curve showing the influence of maximum cooking pressure or temperature on yields indicates that all of the tests were made at pressures above the minimum required for successful cooking, under the conditions employed for these tests; hence, no screenings were obtained from any of the cooks, and the curve for screened unbleached pulp coincides with that for total crude pulp. Increases of pressure from 70 to 120 pounds per square inch resulted in decreasing the yields of pulp about 1 per cent for each five pounds, which indicates that the higher pressures increase the thoroughness of cooking, other conditions being constant.

CONCENTRATION OF CAUSTIC SODA.

The tests varying the initial concentration of caustic soda in the digester liquors were also made within limits that resulted in thorough cooking for all of the tests. Increasing the concentration under the

\footnotetext{
1 Figures 12 and 13 show that the active cooking chemical was consumed at the end of 7 hours at maximum pressure; it is therefore not apparent from these tests what would be the effect of continued cooking in the presence of available caustic soda.
}

$31091^{\circ}-$ Bull. $80-14-2$ 
conditions employed resulted in decreasing the yields of pulp about 1 per cent for each 13 grams per liter increase in concentration. It is thus evident that with a given amount of chemical the greater cooking effect is secured by means of the more concentrated solutions. A practical limit of course exists at the point where the volume of the digester liquor becomes too small to afford favorable cooking conditions. ${ }^{1}$

\section{PROPERTIES OF UNBLEACHED PULPS.}

NATURAL COLOR.

Curves indicating the effects of the conditions of cooking on the natural color of the unbleached pulps are shown in figure 5 .
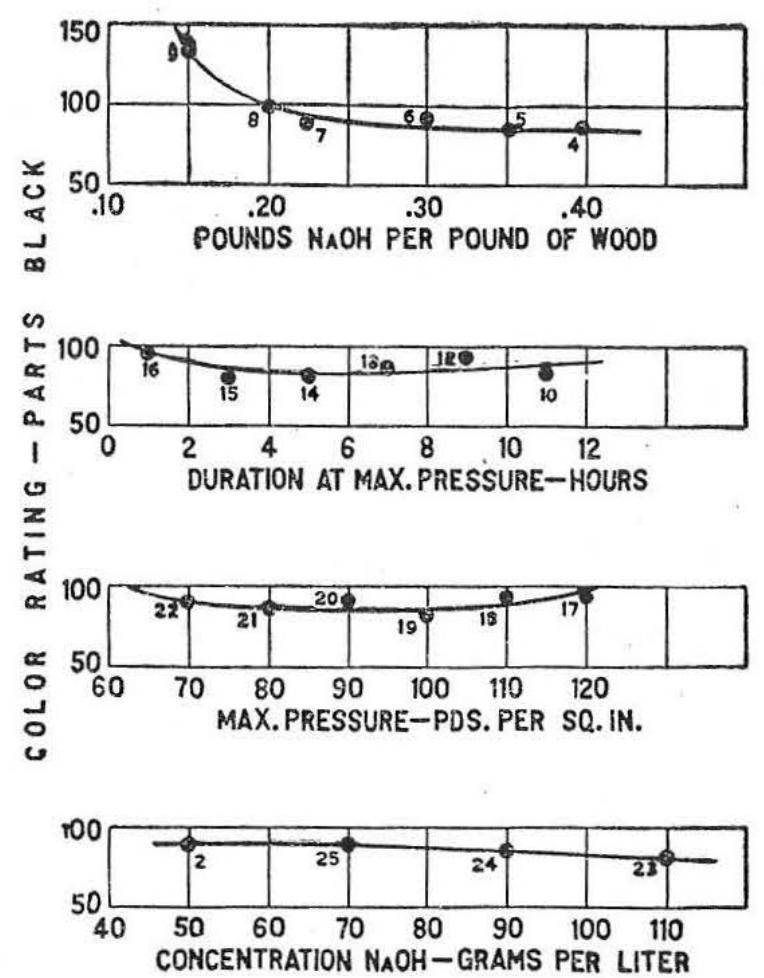

FIG. 5.-Effects of cooking conditions on the color ("parts black") of pulp.

The larger the amount of caustic soda used per pound of wood the lighter in color was the pulp, as indicated by the "parts black" color rating, but the curve approaches parallelism with the horizontal axis as the amounts of caustic increase. White pulps or those with zero "parts black" would not be obtained even if exceedingly large amounts of chemical were used.

Longer periods of cooking produced lighter-colored pulps up to the point where the maximum yield of screened pulp was obtained. Beyond this point there was a tendency for the pulp to become slightly darker as the duration of cooking was increased. This was probably due to the pulp fibers absorbing and retaining coloring matters from the "black liquors." It is generally believed that as the cooking becomes more thorough the cellulose of the fibers gradually becomes more gelatinous or hydrated, and would therefore tend to retain coloring matter during the subsequent leaching and washing treatments.

The pressure (temperature) of cooking seems to have had comparatively little effect on the color of the pulp within the range investigated.

1 As the initial concentrations increased, the volumes of digester liquors at the start of cook decreased (see fig. 17), since the amount of caustic soda was held constant. Hence, increasing concentrations would eventually result in a volume of digester liquor so small that the whole charge of chips would not be covered until late in the cooking period after the liquor had been sufficiently diluted by the condensed steam used in cooking. In this case part of the chips would receive very severe treatment, while the remainder would more or less escape the cooking effect. The resulting pulp would represent a composite of the two conditions. 
The more thorough cooking resulting from the higher initial concentrations of caustic soda produced lighter-colored pulps, although the lower limit of the cooking condition in these tests was considerably above the minimum for successful cooking.

While the several curves shown in figure 5 indicate for each group of tests more or less change in the "parts black" color ratings or the depth of color, the hues of the pulps were not materially affected.

OCCURRENCE OF SHIVES.

Shives are most numerous in pulps from the less severe cooks and are entirely absent from those thoroughly cooked. The shives curves (fig. 6) bear some resemblance to those for the yields of screenings, but shives disappear from the pulps only under somewhat more severe cooking conditions than those which reduced the yield of screenings to zero. At the point of maximum yield of screened pulp the cooking has progressed far enough for the fibers to become more or less separated from each other, but not completely so, since some of them still remain in groups (shives) small enough to pass the screen slots. But as the cooking becomes more severe the fibers are entirely separated, and the resulting pulp is free from shives. In gen-
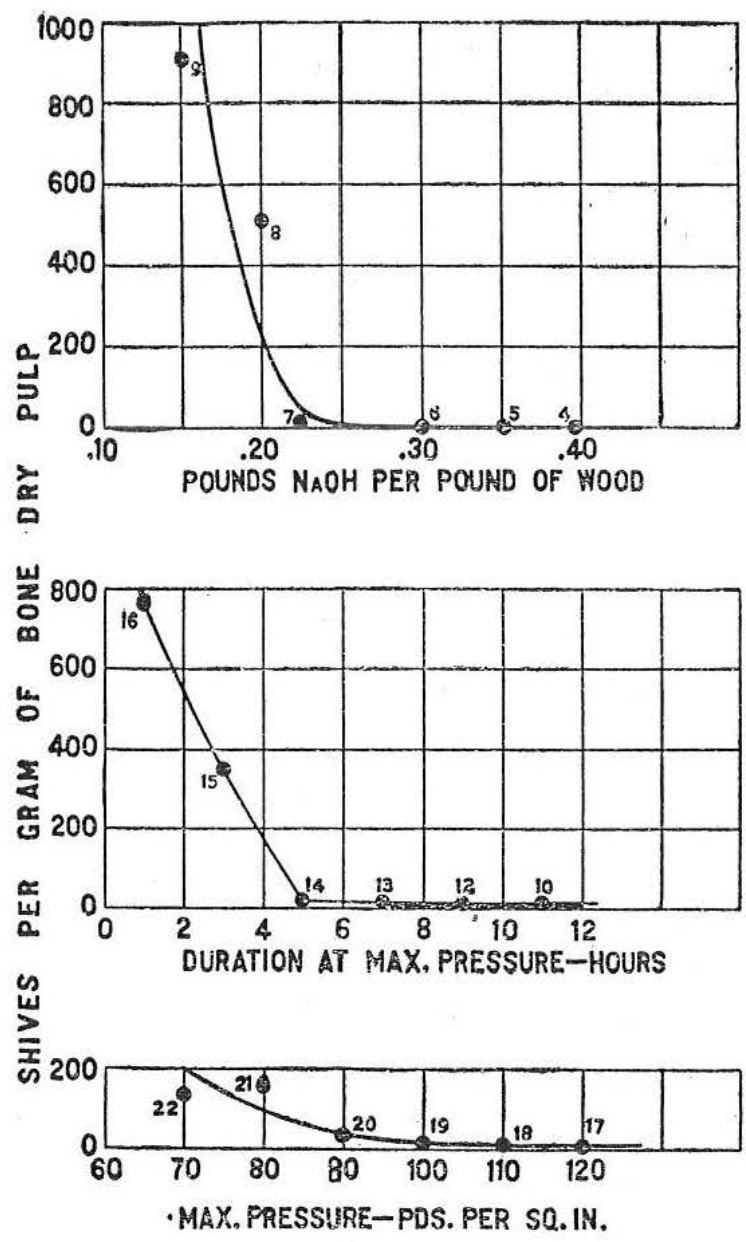

cral, increasing the amount of caustic soda, the duration or the temperature of cooking, or the initial concentration of the digester liquor decreases the "shiviness" of the pulp.

ASH CONTENT.

The curves in figure 7 indicate that increasing the thoroughness of cooking within certain limits decreases the ash content of the pulp; outside of these limits the ash content may be increased.

Since the normal amount of ash in aspen wood is not over threequarters of 1 per cent, the high amounts in the pulps produced 
from this wood in some of the tests is probably due to the presence of cooking chemicals ${ }^{1}$ which were not completely removed during the washing treatments. Increasing amounts of ash as the cooking conditions become more severe may be due to a difference in the physical character of the cellulose produced under such conditions and the resultant increased difficulty of leaching out and washing away any residual and absorbed mineral matters. No tests were
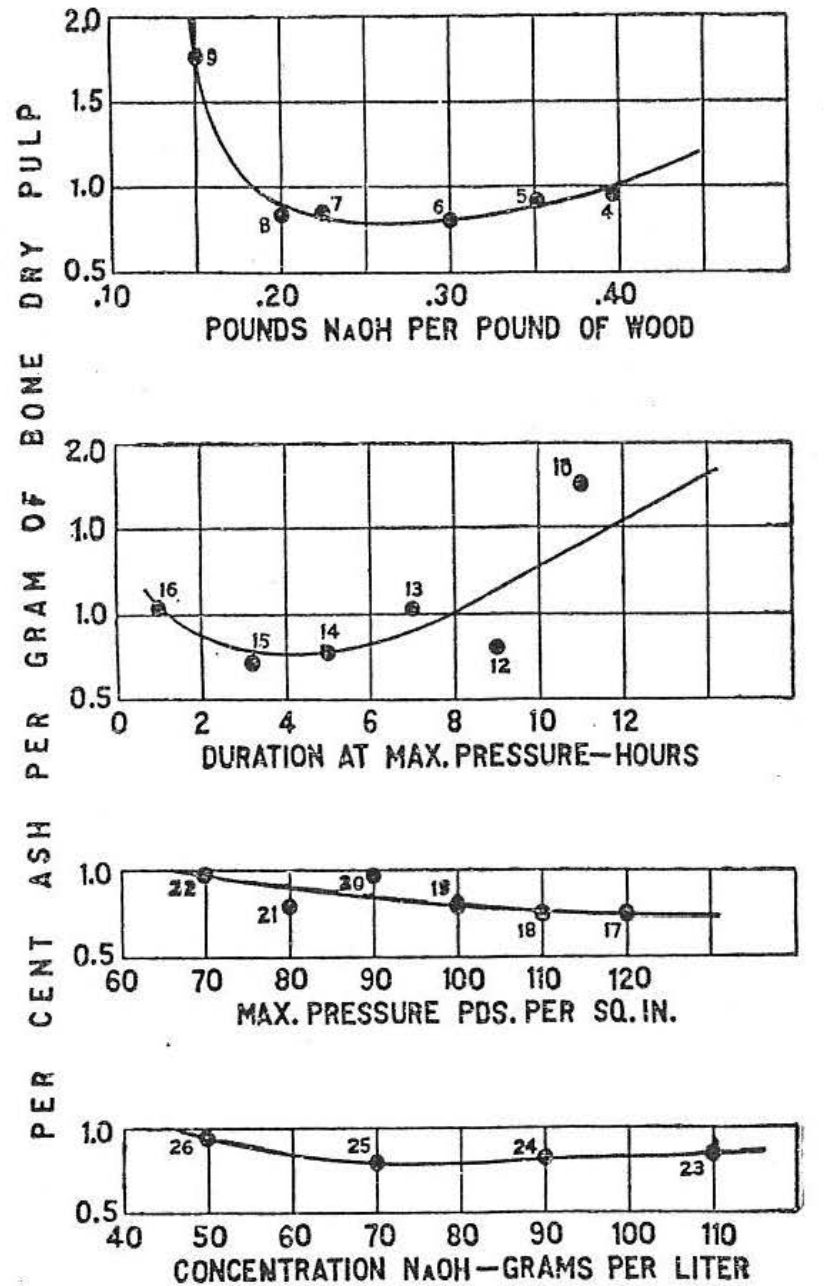

FIG. 7.-Effects of cooking conditions on the ash content of pulp. made to determine the character of the ash from any of the pulps.

STRENGTH.

The strength of a pulp depends chiefly upon three factors-(1) the strength of the individual fibers; (2) the felting or matting quality of the fibers; and (3) the presence of gelatinized fibers and other matters which act as cementing materials.

Severity of cooking is attended by a weakening of the cell walls and may result in a decrease in the strength of the pulp. This decrease of strength was strongly marked in the tests in which the more severe cooking conditions were produced by increasing the amount of caustic soda. It was most rapid up to the point where the fibers were completely separated (indicated by the absence of shives), beyond which it was less pronounced. For increasing durations of cooking the general trend ${ }^{2}$ of the effect was the same as for increasing amounts of chemical, but the total decrease in strength was not quite so great in amount for the range of cooking conditions investigated.

1 Special precautions were taken to eliminate the influence of dirt. Further it does not seem reasonable that the cooking action which removed the lignin and other organic matters should have produced in the fibrous residue or pulp a concentration of the mineral constituents which go to form the wood ash.

2 The data are not sufficient for expressing the effect in detail. The true curve would be expected to have a bend coinciding with the point of maximum yield of screened pulp or the point where the shives are reduced to zero. 
Increasing the pressure and increasing the initial concentration beyond a certain point both increased the strength of the pulp. This effect is apparently contradictory to that found for the other two groups of tests and may possibly be due to the high temperatures and high concentrations which would tend to cause a physical change in the cellulose with increase of the cementing effect mentioned previously.

Curves showing the influence of cooking conditions on the strength of pulp are given in figure 8 .

EASE OF BLEACHING.

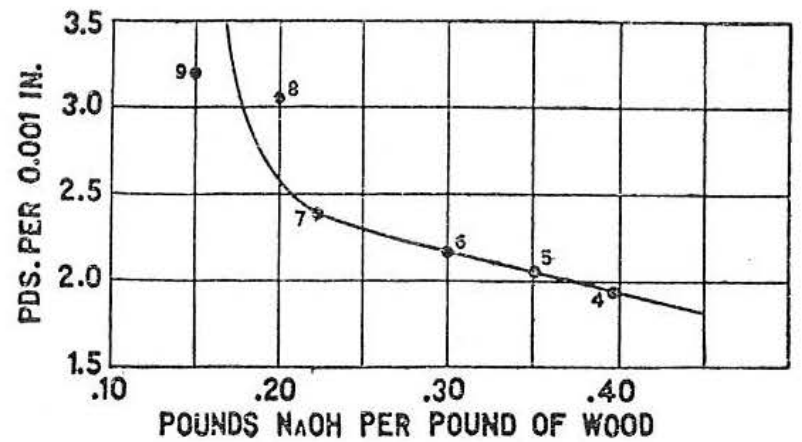

The chief purposes of bleaching are (1) to produce a white pulp and (2) to destroy any noncellulose materials which tend to make the pulp less durable. The more nearly the original pulp approaches to pure cellu-

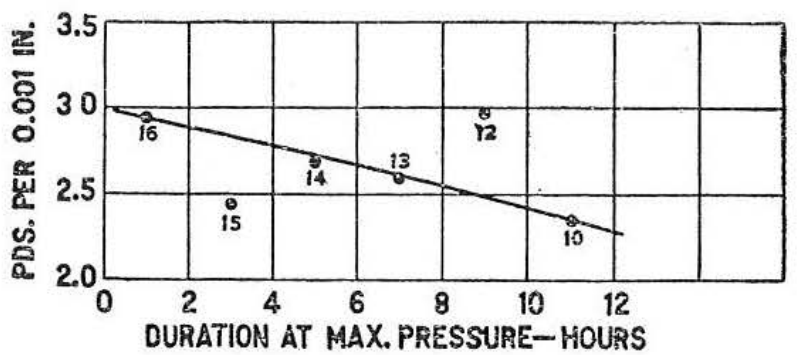
lose the less is bleaching required. However, difficulty of bleaching is occasioned not only by the presence of ligneous matters, but also by coloring matters absorbed in the cell walls from the "black liquors" and by the residual cooking chemicals which the leaching and washing treatments have failed to remove. In the latter case a certain amount of bleach is neutralized by reactions with the other chemicals.

Curves expressing the effects of varying the cooking condi-
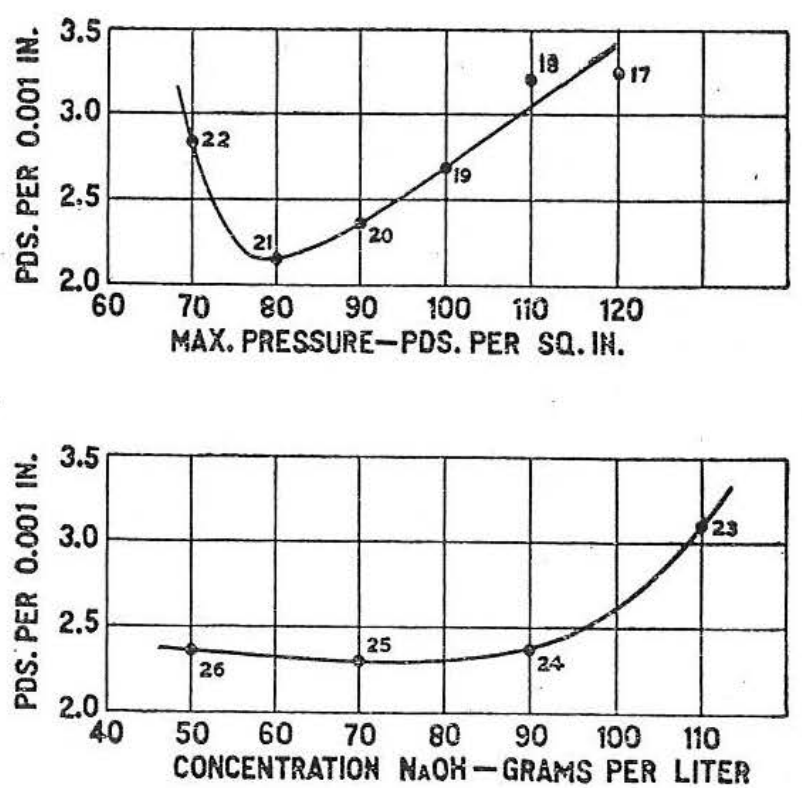

FIG. 8.-Effects of cooking conditions on the strength of pulp.

tions on the ease of bleaching, as measured by the amount of bleach required to bring the pulps to a standard white color, are shown in figure 9. These curves show that under the conditions of cooking the residual ligneous matters are the most important factor in determining the amount of bleach required, since the more thorough cooking produces pulps that are more easily bleached. The decrease in amount of 
bleach required was very rapid up to the point where shives were eliminated; beyond this point the effect was less marked. It must not be assumed, however, that the shives alone necessitated the larger amounts of bleach. The presence of shives indicates an incomplete cooking reaction and implies that considerable ligneous matter may remain in the other (completely separated) fibers.
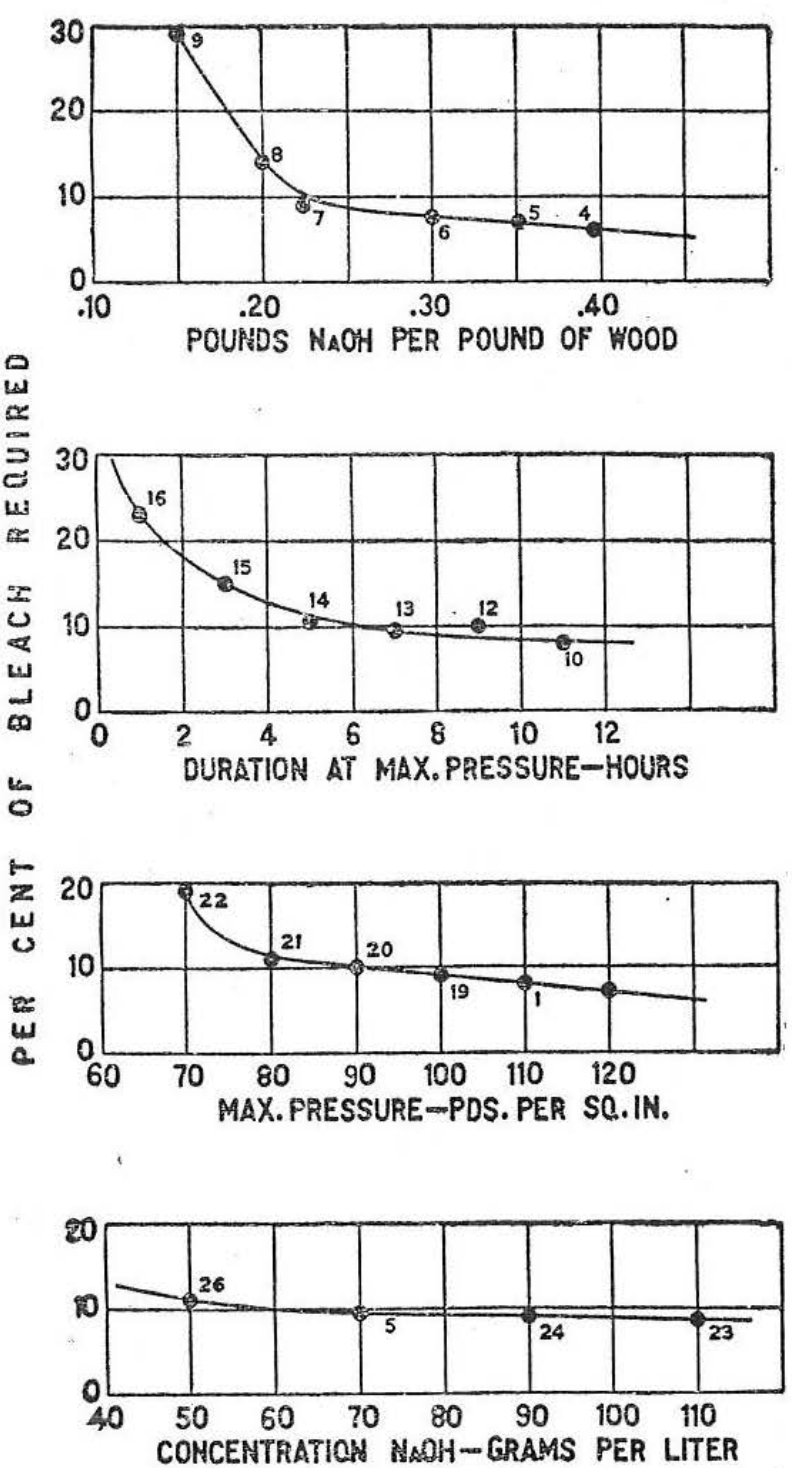

Fig. 9.-Effects of cooking conditions on the ease of bleaching.

The effect of severity of the cooking conditions is especially noticeable in the curves for the tests varying the amount of caustic soda and the duration of cooking, since certain of the pulps produced in these tests were less thoroughly cooked than any of those from the other groups.

\section{LOSS ON BLEACHING.}

The curves showing the losses on bleaching as affected by the varying cooking conditions are given in figure 10 . As would be expected, the loss decreased with thoroughness of cooking. In the tests varying the amounts of chemical and the durations of cooking the rate of decrease in bleaching loss with greater severity of cooking was fairly constant, but it is probable that if the cooking conditions were extended for higher values than those used the curves would approach parallelism with the horizontal axis. Such an effect was obtained for the tests in which the cooking pressures were varied. It is not reasonable to believe that more severe cooking would result in pulps which would suffer no loss whatever on bleaching.

The platted points for the tests in which the initial concentrations were varied are so few in number and so irregular in location that they give little indication of the influence of this factor. However, additional information is obtained from some earlier tests of the Forest Service, summarized in Table 4. 
TABLE 4.--Effect of concentration on bleaching losses (autoclave tests). ${ }^{1}$

\begin{tabular}{|c|c|r|r|r|r|}
\hline $\begin{array}{c}\text { Cook } \\
\text { No. }\end{array}$ & $\begin{array}{c}\text { Concentra- } \\
\text { tion of } \\
\text { NaOH. }\end{array}$ & $\begin{array}{c}\text { Yield of } \\
\text { total crude } \\
\text { pulp. }\end{array}$ & $\begin{array}{c}\text { Yield of } \\
\text { screenings. }\end{array}$ & $\begin{array}{r}\text { Bleach } \\
\text { required. }\end{array}$ & $\begin{array}{c}\text { Loss on } \\
\text { bleaching. }\end{array}$ \\
\hline & & & & & \\
\hline & $\begin{array}{c}\text { Grams per } \\
\text { liter. }\end{array}$ & Per cent. & Per cent. & Per cent. & Per cent. \\
2 & 50 & 41.10 & 0.10 & 15.4 & 3.92 \\
4 & 30 & 46.23 & .03 & 14.7 & 4.08 \\
& & .07 & 15.8 & 4.68 \\
\hline
\end{tabular}

1 Each cook employed seven hours' duration at 110 pounds pressure per square inch. The caustic soda charged amounted to 0.25 pound per pound of wood. For complete information see appendix, Table 15 .

These data indicate that increasing the concentration reduces the loss c $\mathrm{n}$ bleaching, hence the curve in figure 10 has been drawn to show such an effect. This is substantiated by the fact that varying the amount of chemical and the duration and pressure of cooking in each case showed a reduction in the bleaching losses as the severity of cooking increased, and that most of the other curves for the effect of concentration (especially the yield, shives, and bleach-required curves) show more severe cooking with the higher concentrations.

The relatively large amount of loss in the case of cook 23 does not seem to be warranted in view of the well-cooked condition of the pulp. However, the comparatively high strength of the pulp indicates an abnormal condition.

The loss in weight of a pulp during bleaching is due primarily to the removal of the colored ligneous matters and to the partial destruction of the cellulose itself. The latter is especially liable to occur if the
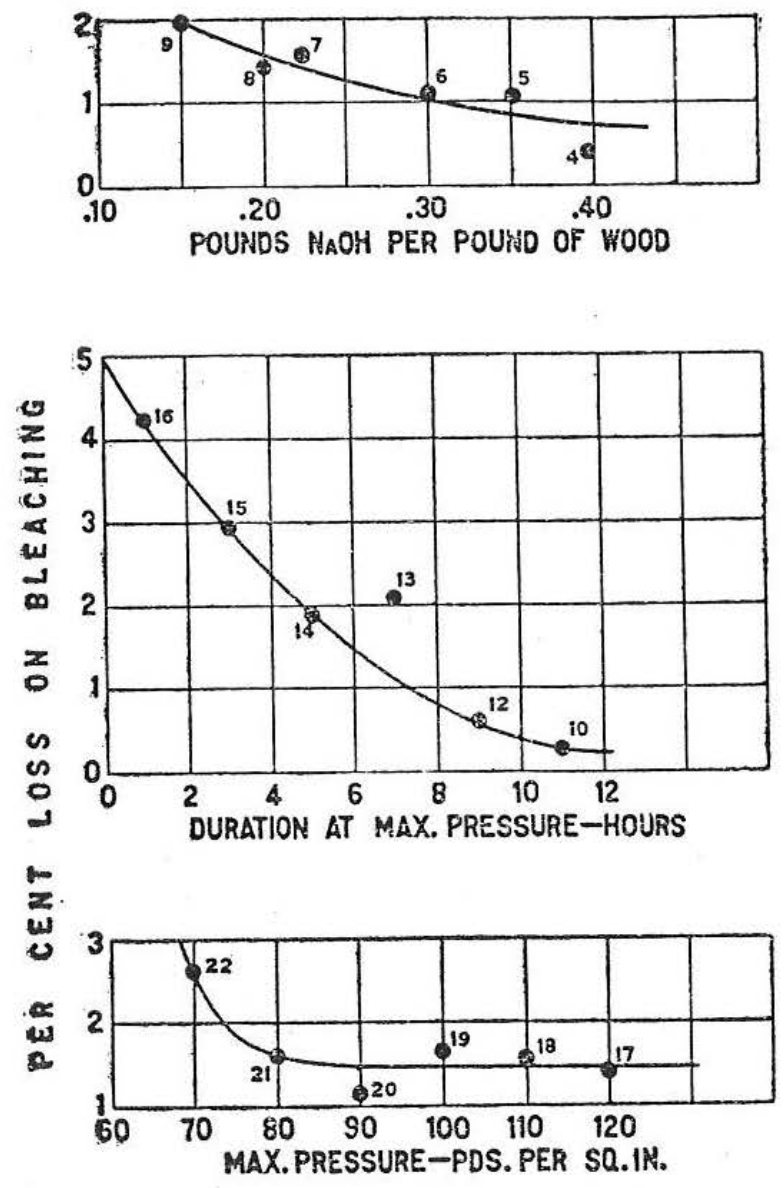

bleaching treatments are severe, or if the cooking treatments have left the cellulose in an easily oxidized condition, so that it is either dis- 
solved during bleaching or broken up into small particles, which are removed in the washing operations. The partial removal of the mineral or ash-forming constituents from the pulp may also occasion some loss. On the other hand, the ash in bleached pulp sometimes tends to increase over that for the unbleached pulp (due to an accumulation of lime compounds and other residues from the bleaching solution), and hence may offset the loss due to other causes.

RELATION BETWEEN PROPERTIES AND YIELDS.

Many of the curves expressing the effects of the varying cooking conditions on the properties of the unbleached pulps have bends or

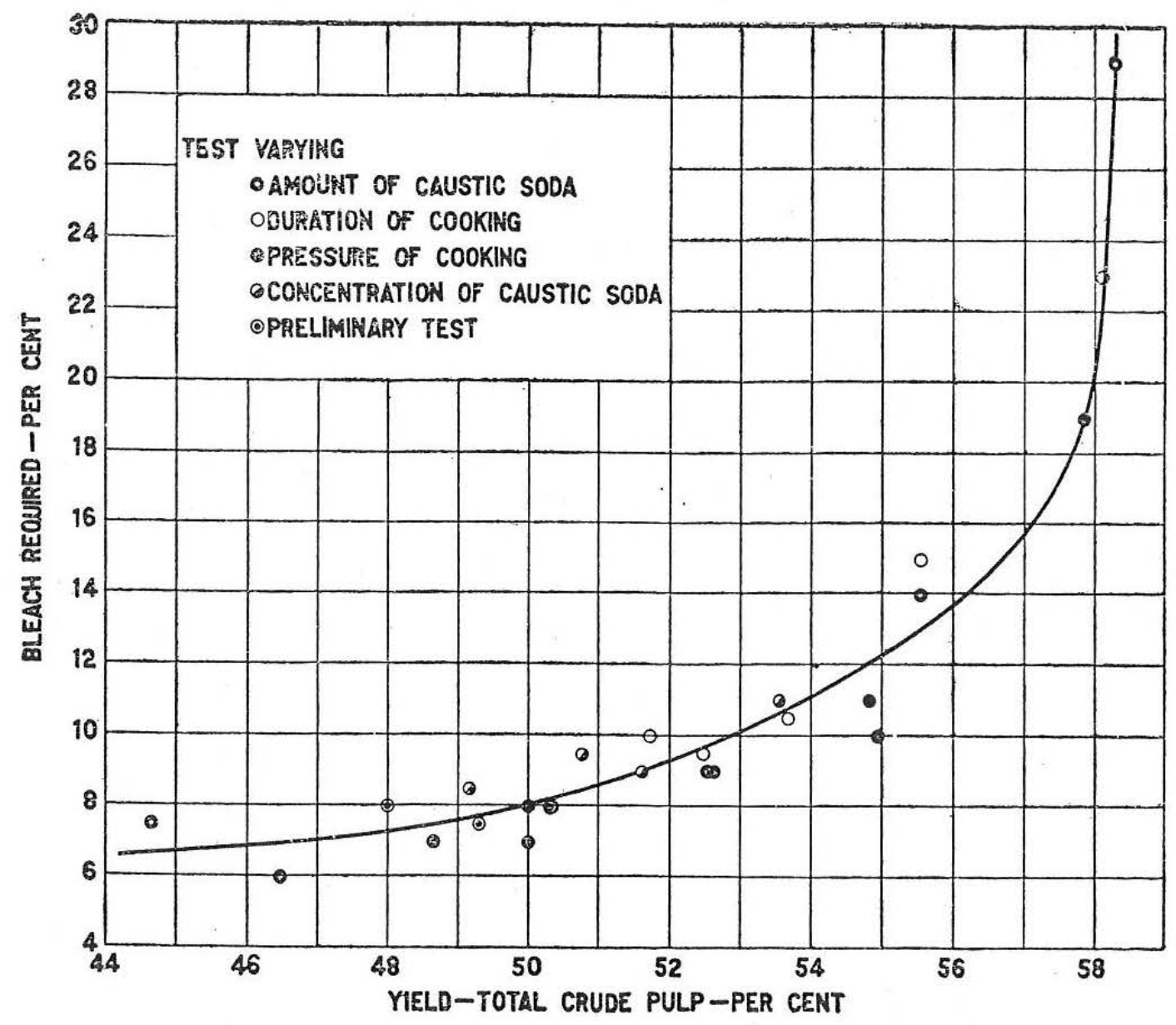

Frg. 11.-Relation between yields and ease of bleaching.

"breaks" at or near the values for the cooking conditions which resulted in the highest yields of screened pulp. So general is this that, with decreasing severity of cooking, the occurrence of sudden changes of direction for curves expressing properties affords a reliable indication that the yield of screened unbleached pulp is near its maximum. This is especially evident in the curves for ease of bleaching.

That properties of pulps are directly dependent upon yields is well illustrated when amounts of bleach required are platted against yields of total crude pulp, as in figure 11. Values for all of the cooks made in these experiments have been platted, irrespective of the testing 
conditions under which they were secured. It is evident that cooks which resulted in decreased yields produced easier bleaching pulps. For the higher values slight differences in yields are accompanied by marked differences in the ease of bleaching, but the effect rapidly diminishes until a large decrease in the yields affords little difference in the amounts of bleach required. This would be expected in view of the nature of the cooking reactions. The effect is first to remove the intercellular substances and part of the ligneous matters from the wood, then the cellulose itself begins to be attacked, and finally, after the greater part of ligneous matters has been removed, the cellulose alone is affected. The ease of bleaching is a measure of the amount of noncellulose matters present in the pulp.

Other properties of the pulps when similarly platted against yields show more or less definite relationships, but are apt to be modified according to the cooking condition varied. For instance, when varying the amount of caustic soda or the duration of cooking, decreased yields were attended by decreased strength of pulp; when initial concentrations or pressures were varied, the strength increased as the yields decreased. Natural color, shives, and screenings, however, were little affected for yields below 54 per cent, no matter how produced; for higher yields the color, shives, and screenings increased rapidly with increasing yields. The losses on bleaching followed fairly closely the amounts of bleach required, and hence decreased as the yields decreased.

SIGNIFICANCE OF PROPERTIES.

There are at present no accepted standards of quality or market grades of soda pulps. What may be sufficiently good quality for one purpose or one mill may be poor or medium quality for another. Áside from bulkiness and opacity, which depend mainly on conditions not studied in these experiments, the desirable properties of a pulp are, in general, as follows:

(1) Low percentage of bleach required.

(2) Low loss on bleaching.

(3) High strength.

(4) Durability (resistance to wear and decomposition).

(5) Low ash content.

(6) Few shives.

(7) Absence of dirt.

(8) Light color for the unbleached pulp.

(9) Whiteness of the bleached pulp with freedom from certain undesirable tints.

It is not often that any one pulp has the advantage over another in all of these properties, and for many uses some of them are of no importance. For aspen (poplar) or other short-fibered pulps used in the manufacture of book papers the properties which are given most 
consideration are freedom from dirt and shives and low percentage of bleach required, with the attendant low loss on bleaching. Both undercooked and overcooked pulps are to be avoided.

\section{CONSUMPTION OF CAUSTIC SODA.}

By consumption of caustic soda is meant the neutralization of the free or active caustic soda $(\mathrm{NaOH})$ existing as such in the digesting
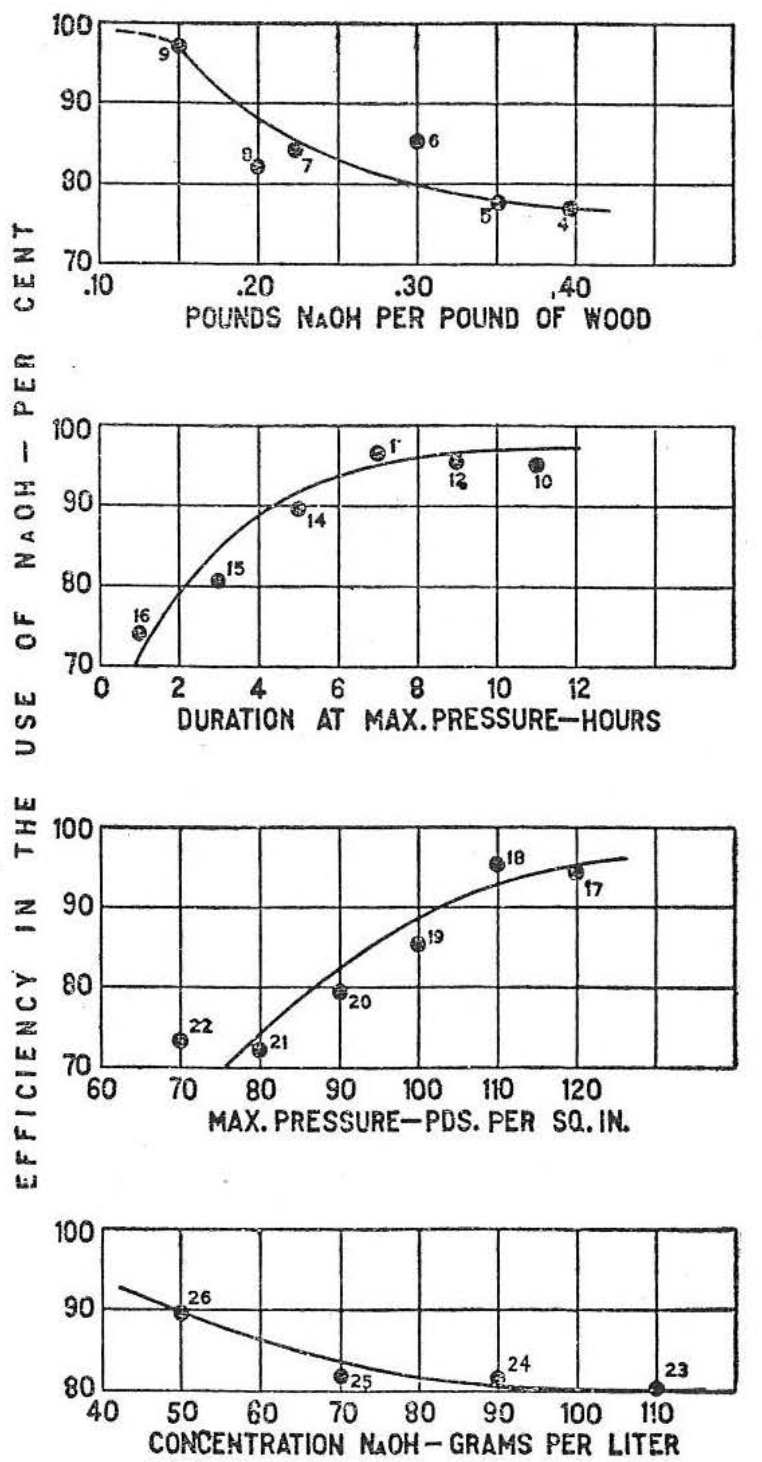

FIG. 12.-Effects of cooking conditions on the efficiency in the use of caustic soda. liquors. The neutralization results from the combination of the sodium $(\mathrm{Na})$ of the alkali with the acid products derived from the hydrolysis of the lignified fibers during cooking. ${ }^{1}$ The black liquors at the end of the cooking treatments contain in dissolved form these nonalkaline, sodium compounds, together with the remaining free caustic soda.

The effects of varying the cooking conditions on the consumption of caustic soda, expressed in per cent of the amount charged or the efficiency in its use, are shown in figure 12. The actual consumption in pounds per 100 pounds of wood is shown in figure 13 .

As would naturally be expected, the greatest comparative efficiency for the cooks made with varying quantities of caustic soda resulted from the use of the smaller amounts. However, when very small amounts were employed, the cooking reactions were not sufficiently complete, ${ }^{2}$ as indicated by the curves for yields and properties of the pulps. In this group of tests well-cooked pulps were first obtained with about 0.2 pound of $\mathrm{NaOH}$ per pound of wood. The efficiency in the use of the caustic at this point was about 85 per cent.

1 See De Cew's discussion, p. 6.

$2 \mathrm{It}$ is a well-known chemical law that in order to carry a reaction to a given degree of completion for one of the reacting substances it is necessary to have a vailable a certain excess of the other chemical or chemicals which take part in the reaction. This means that the efficiency in the use of the chemical can not be 100 per cent. The speed of the reaction is proportional to the amount of the excess. 
With increasing durations of cooking the efficiency in the use of caustic soda increased until it reached a constant maximum value. An efficiency of 95 per cent was obtained by seven hours' cooking at maximum pressure, and, since no greater efficiency was secured by continuing the cooking four additional hours, it is apparent that this represents the maximum efficiency attainable. That the cooking reactions are not due entirely to the presence of active caustic soda is indicated by the fact that after the 95 per cent efficiency had been attained increased durations resulted in some further cooking effect ${ }^{1}$ (see curves for yields and properties of pulps) with no increase in the amount of chemical consumed. Increasing the pressure also resulted in greater efficiency in the use of caustic soda until a maximum of 95 per cent was obtained.

In all groups of tests in which a constant amount of caustic soda was charged into the digester for each cook, greater percentage efficiency in its use could mean only a greater actual consumption of the chemical. In the group of tests varying the amounts of caustic soda, the decrease in percentage efficiency was accompanied also by increase in the actual consumption. It is thus apparent that the more thorough cooking, whether produced by increasing the amount of chemical in the charge or the duration or the
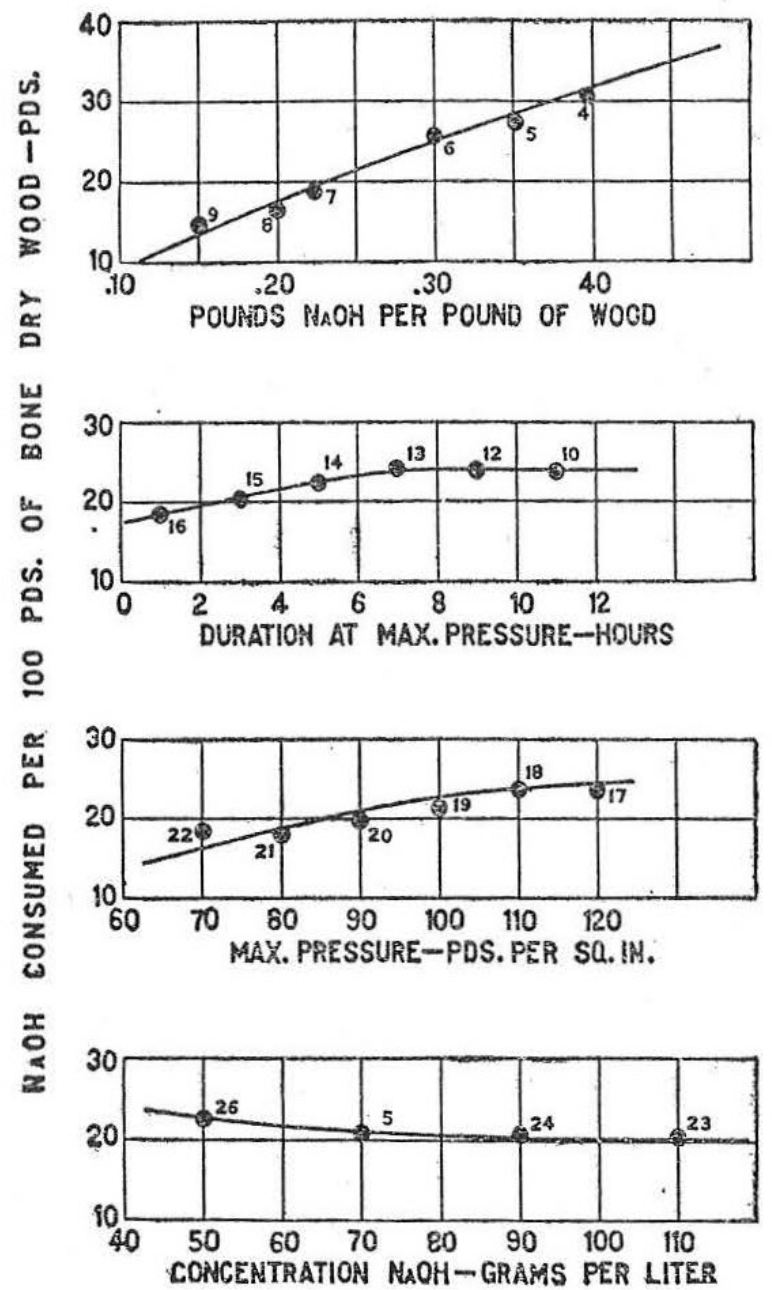

FIG. 13.-Effects of cooking conditions on the amount of caustic soda consumed. pressure of cooking, is, in large part at least, due to the greater completeness of the reaction between the chemical and the wood.

The tests employing various initial concentrations of caustic soda in the digester liquors (the amount of caustic soda charged remaining: the same) seemingly do not bear out this conclusion. In most respects the determinations of yields and properties of the pulps in these tests indicated that the more concentrated solutions resulted in more thorough cooking, but no increase in the consumption of chemical occurred; in fact, with increase of concentration, a decrease 
of consumption and subsequently decrease of percentage efficiency are indicated. While the possibility of error is not eliminated, ${ }^{1}$ this result indicates the need for further investigation.

\section{RELATION BETWEEN CAUSTIC SODA CONSUMED AND YIELDS.}

For the purpose of further studying the cooking effects of the various conditions employed, yields of total crude pulps from all of the cooks were platted against amounts of caustic soda consumed per 100 pounds of wood charged (fig. 14). The average curve drawn through these points indicates a definite relation between yields and

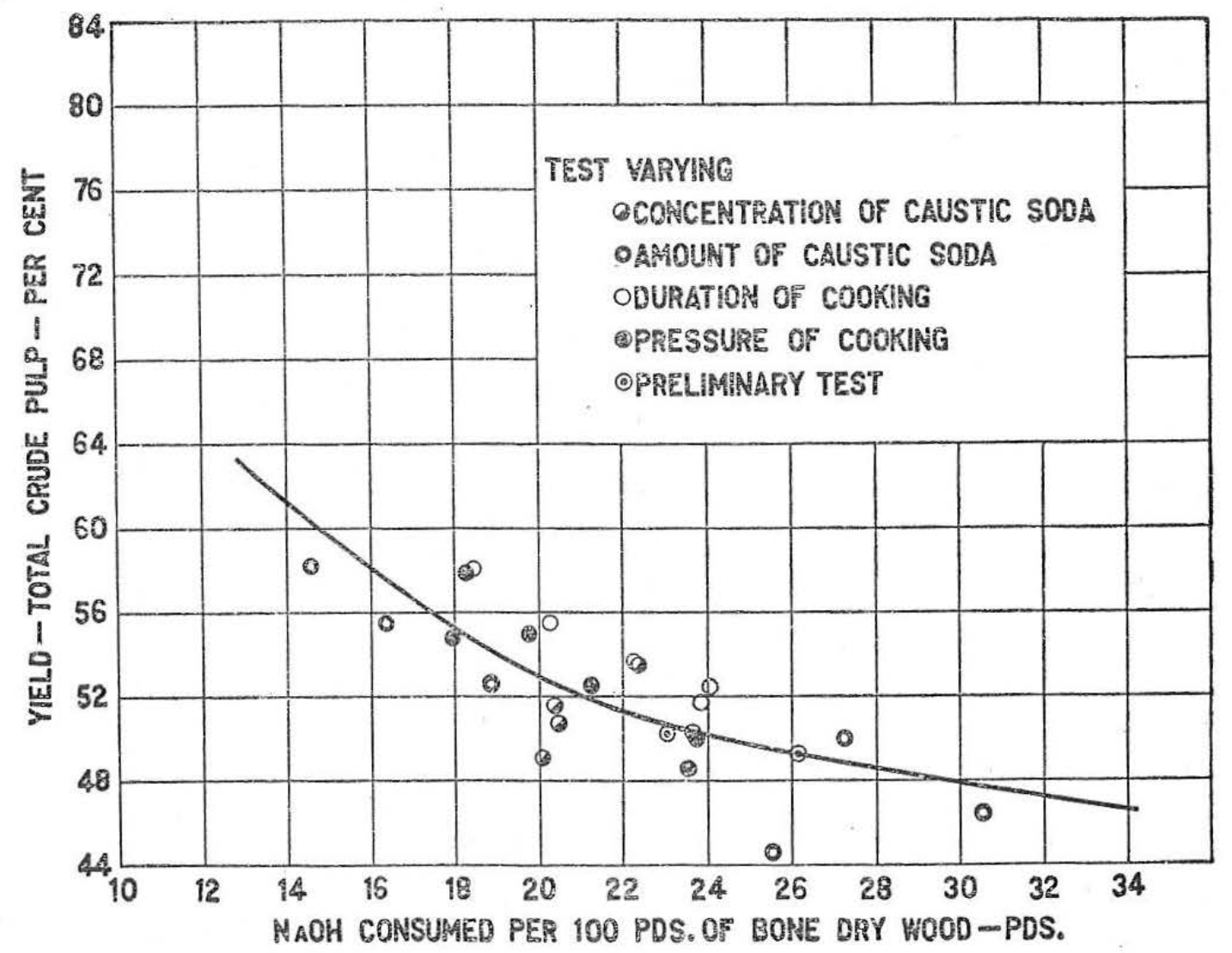

FIG. 14.--Relation betwcen yields and amount of caustic soda consumed.

amounts of caustic soda consumed, regardless of the cooking conditions. However, even if it is assumed that the location of some of the points is due to experimental errors, the relation, as regards individual cooks, can be only an approximate one, since it has already been pointed out that in some of the tests increased cooking effects were obtained without any increase in the consumption of caustic soda. If the curve were produced for lower amounts of caustic soda, the yields would probably be somewhere between 80 and 100 per cent at zero consumption, since under these conditions cooking could still be effected by water alone. ${ }^{2}$

1 The test data show a loss of digester liquor overflowing through the "top relief" for cooks 25 and 26 (that for cook 26 showing the greatest loss), and it is due to the platted points for these two cooks that the curves indicate greater consumption of caustic soda at the lower concentrations.

2 See Tauss's experiments, Table 1. 
Since the completion of these experiments Mr. E. Sutermeister has published ${ }^{1}$ the results of some tests in which a small rotary autoclave and copper flasks were used as cooking vessels. Yields varying from 93 to 24 per cent and consumptions of caustic soda varying from 0 to 29 pounds per 100 pounds of wood were obtained, ${ }^{2}$ giving a relation similar to that indicated by the curve in figure 14: However, in his experiments a greater reduction of yields was obtained per unit decrease in the caustic soda consumed, which is probably due to differences in test material, method of experimentation, and apparatus employed.

The actual consumption of caustic soda during cooking is a factor which is not given sufficient consideration in commercial practice, although it is one of considerable importance for an intelligent control of the cooking operations. By a careful study of the consumption, together with the other effects of the various cooking conditions, it is possible to determine the best operating conditions. That pulp mills do not ordinarily determine the consumption of caustic soda and the efficiency of its use is due to the length of time necessary for the analysis of the black liquors. While the method used in these experiments requires some time for carrying out the analysis, its occasional use in commercial operations would be of benefit in determining the conditions to be used in future cooks. ${ }^{3}$ If there were a rapid and accurate method of analysis such as is used in sulphite mill operations, it would assist in determining when the cooking had progressed far enough, at which time the digester could be blown. Production of undercooked or overcooked pulps would thus be avoided.

SEVERITY OF COOKING AS INDICATED BY MICROSCOPIC APPEARANCE OF FIBERS.

A good indication of the thoroughness or severity of cooking may be obtained by microscopic examinations of the pulp fibers. ${ }^{4}$ The effects of varying the cooking conditions are shown in figure 15; curve A represents the relative abundance of vessels in the pulps; curve B, the ray cells; curve C, the fiber bundles or shives; curve D, the prominence of the vessel markings; and curve E, the apparent strength of fiber walls. Since there are no absolute units for measuring these effects, the ordinates as shown for each curve represent arbitrary units ranging from 0 to 10 . The photomicrographs in Plates II to VII, inclusive, present some of the more pronounced

1 Paper, p. 15, No. 2, vol. 9, Sept. 25, 1912.

${ }^{2}$ In obtaining yields higher than 75 per cent the test material was treated at atmospheric pressure. Under this condition the cooking effect of water alone would have but little influence unless long durations of treatment were used.

3 The boiling of rags with caustic-soda solutions for the production of rag pulps is controlled in this manner.

1 For the normal appearance of fibers in the uncooked wood see Plates VIII and IX, as well as the discussion on p. 42. 
effects. ${ }^{1}$ While various gradations resulted, ${ }^{2}$ the experimental pulps may be classified in the following three groups:

Overcooked pulps.-Severe digestion treatments resulted in "overcooked" pulps, examples of which are seen in Plates II and III. The walls of the fibers show a considerable degree of weakness, as indicated by their thin transparent appearance and by their much twisted and fractured condition. The relative number of vessels present in the pulp is low as compared with the normal number present in the wood, and the pits and other markings on them are only dimly visible. Many of the vessels remaining are
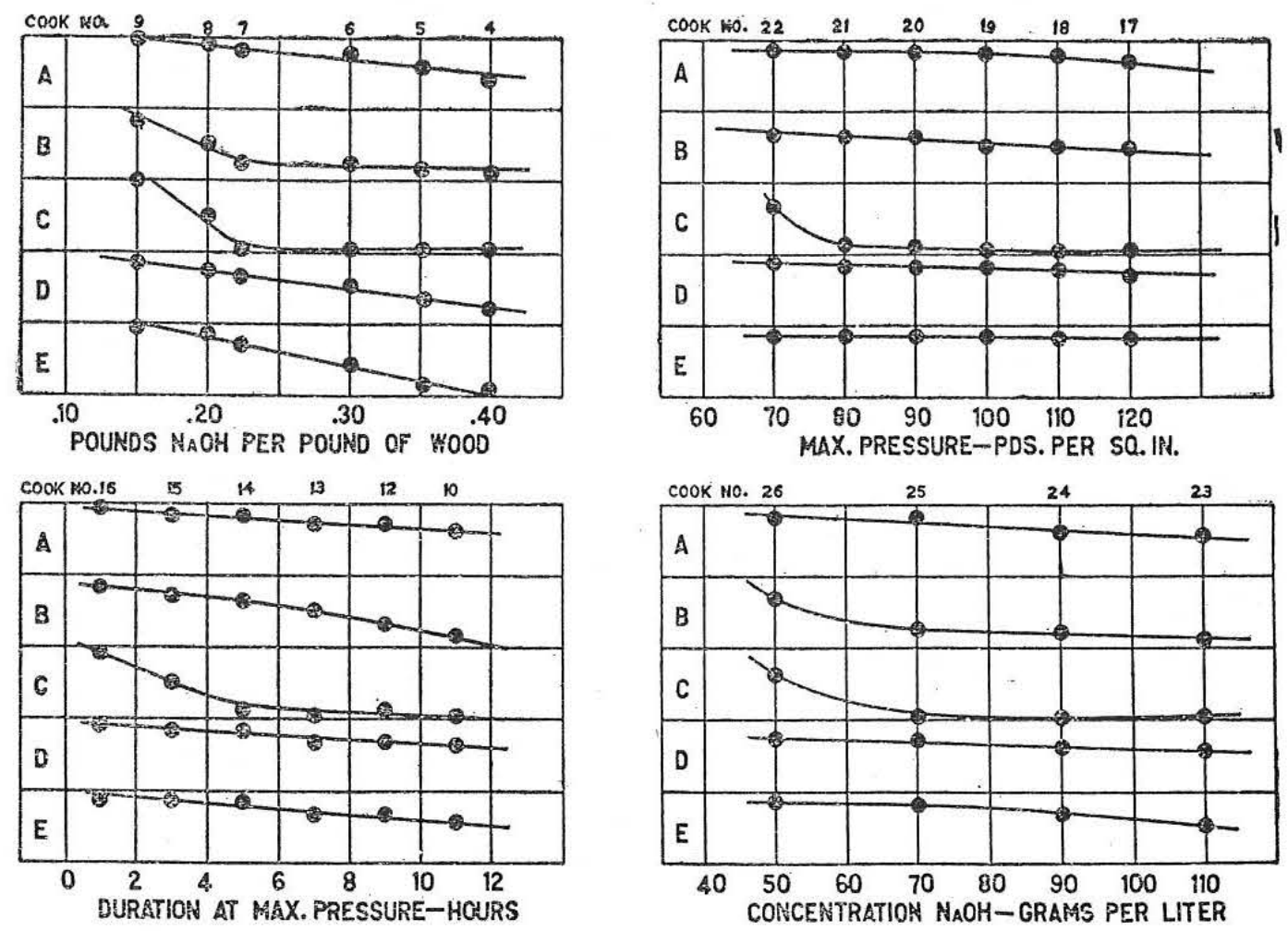

Fig. 15.-Effects of cooking conditions on pulp fibers. $\Lambda$, abundance of wood vessels; $B$, ray cells; $\mathrm{C}$, fiber bundles, or shives; D, prominence of vessel markings; and $\mathrm{E}$, apparent strength of fiber walls.

- ragged and partly di.integrated; and the pulp, for the most part, is also characterized by an absence of the comparatively thin-walled, delicate ray cells. Fiber bundles also are absent, since these are made up of fibers bound together by groups of the brick-shaped ray or parenchyma cell. The indistinctness of the vessels and fibers is due chiefly to the removal of the ligneous infiltrations of the cell walls, in consequence of which the elements developed very little color from the particular stain used in making the microscopic mounts.

Well-cooked pulps.-Pulps produced under less severe conditions are made up of stronger fibers, such as shown in Plates IV and V.

1 The remarks following the title of each plate and the discussion in the text are not based on the fields shown in the photomicrographs alone.

2 The photomicrographs, in the order of their sequence, show gradations of severity of cooking. 
The milder treatments are apparent in the increasing number of ray cells and vessels, the latter being well preserved and showing their markings quite clearly. The fibers are twisted or broken to only a small extent, and yet are so well separated that there are no fiber bundles.

Undercooked pulps.-Plates VI and VII illustrate the characteristics of undercooked pulps, and show plainly the mildness of the digestion treatments employed in their production. Well-preserved vessels with sharply defined markings are clearly visible, ray cells are numerous, and the walls of the fibers are less dissolved away than in the more thoroughly cooked pulps. Coincident with these characteristics there are also present many fiber bundles or shives, noticeable even when the microscopic slides are examined with the naked eye. Undercooked fibers develop a deep color from the particular stain used in mounting, and on this account appear very distinct.

Of the several groups of tests, the one varying the amounts of caustic soda per pound of wood resulted in the greatest range of severity of cooking as determined by the microscopic appearance of the pulp fibers. A small amount of chemical resulted in an undercooked pulp. With increases in the amount the strength of cell walls gradually decreased, the wood vessels suffered gradual destruction, and their markings were dimmed. The ray cells and fiber bundles disappeared soon after the point was reached where the maximum yield was attained. The higher amounts of caustic gave the overcooked effects.

For varying durations of cooking the effect was practically the same, and undercooked pulps were obtained at the shortest duration used. However, the highest durations employed did not give as severely cooked pulps as were obtained with large amounts of chemical. While all of the tests varying the cooking pressures resulted in fairly well cooked pulps, there was a tendency toward undercooking at the lowest pressure used. The tests varying the initial concentrations also resulted in well-cooked pulps, except for the highest concentration, where a slight overcooking effect was observed.

\section{INFLUENCE OF COOKING CONDITIONS ON COST.}

While it is not feasible from the data at hand to discuss all cost factors affecting the commercial production of pulps, the more direct effects of the cooking conditions employed can be shown. The actual effects on the cost of production, of course, depend upon various other operating conditions at any particular mill, but the general trend of the effects is the same, irrespective of local conditions.

TIME.

Shorter durations of cooking result in more efficient use of the digesting apparatus; more cooks can be made per day or per week, 
and, as has been shown, yields of pulp per unit of wood are also increased, and consequently more pulp is secured per cook. The greater plant capacity thus obtained would result in a proportionate decrease of operating costs per ton of pulp.

Figure 16 shows the production of pulp per 24 hours continuous operation for each 100 pounds of wood capacity of digester as influenced by various durations of cooking. The curve was derived from the experimental data, assuming a one-hour period for blowing the digester after completing a cook and for charging the next cook, and

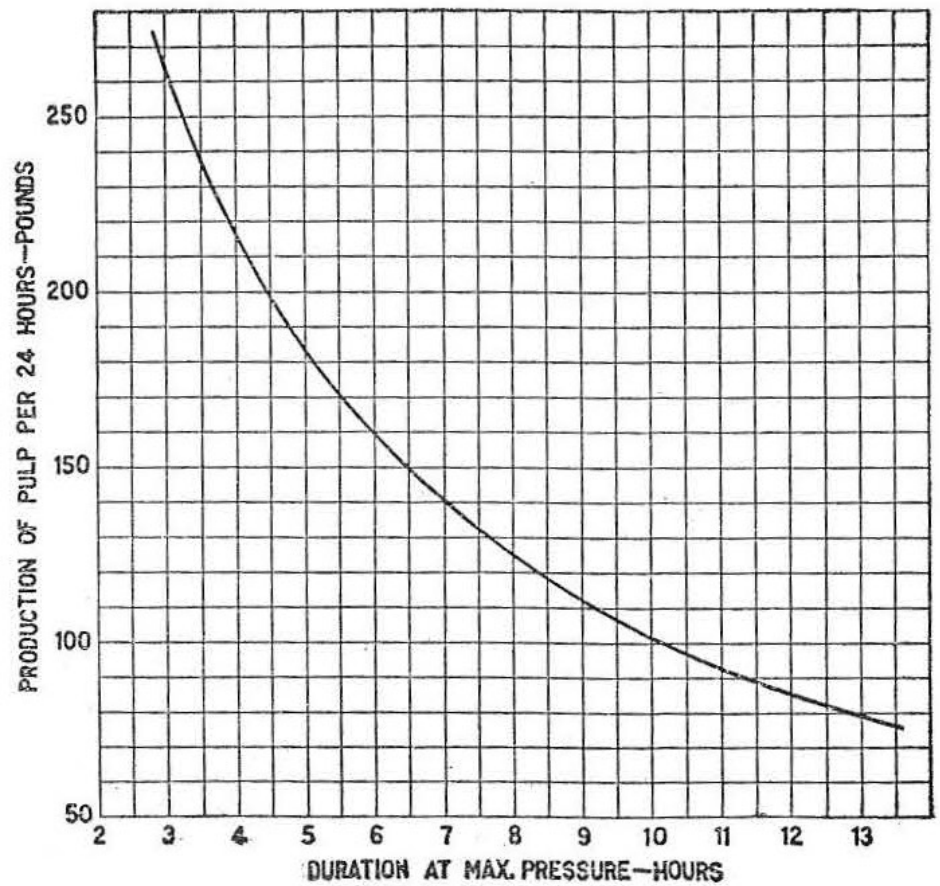

FiG. 16.-Effect of duration of cooking on production in 24 hours. a similar period for attaining maximum cooking pressure. Thus, for a three-hour period at maximum pressure, the total time between the charging of two consecutive cooks is five hours. Computation shows that decreasing the duration at maximum pressure from eight to five hours increases the daily output 48 per cent, while a decrease from ten to three hours increases the output 156 per cent. If the time allowed for blowing and charging the digesters and for raising the digester pressure is decreased, the increase in the daily output will be even more pronounced as the duration of cooking is shortened.

\section{STEAM CONSUMPTION.}

While the consumption of steam varies with the duration of cooking, it is influenced also by the pressure maintained in the digester and more by the relative volumes of the liquor charge. Under the testing conditions employed, the volume of liquor varied both with the amount of caustic soda charged (the concentration being constant) and with the concentration (the amount of chemical being constant). Since the heating was accomplished by steam blown directly into the digester, a measure of the amount of steam used is afforded by the increase in the volume of liquor during cooking. ${ }^{1}$ The effects of the

\footnotetext{
1 The steam used was not perfectly dry, containing a small amount of moisture or "priming." However, as the steam was of approximately the same moisture content for all tests, the "condenșation" was proportional to the amount of steam used.
} 


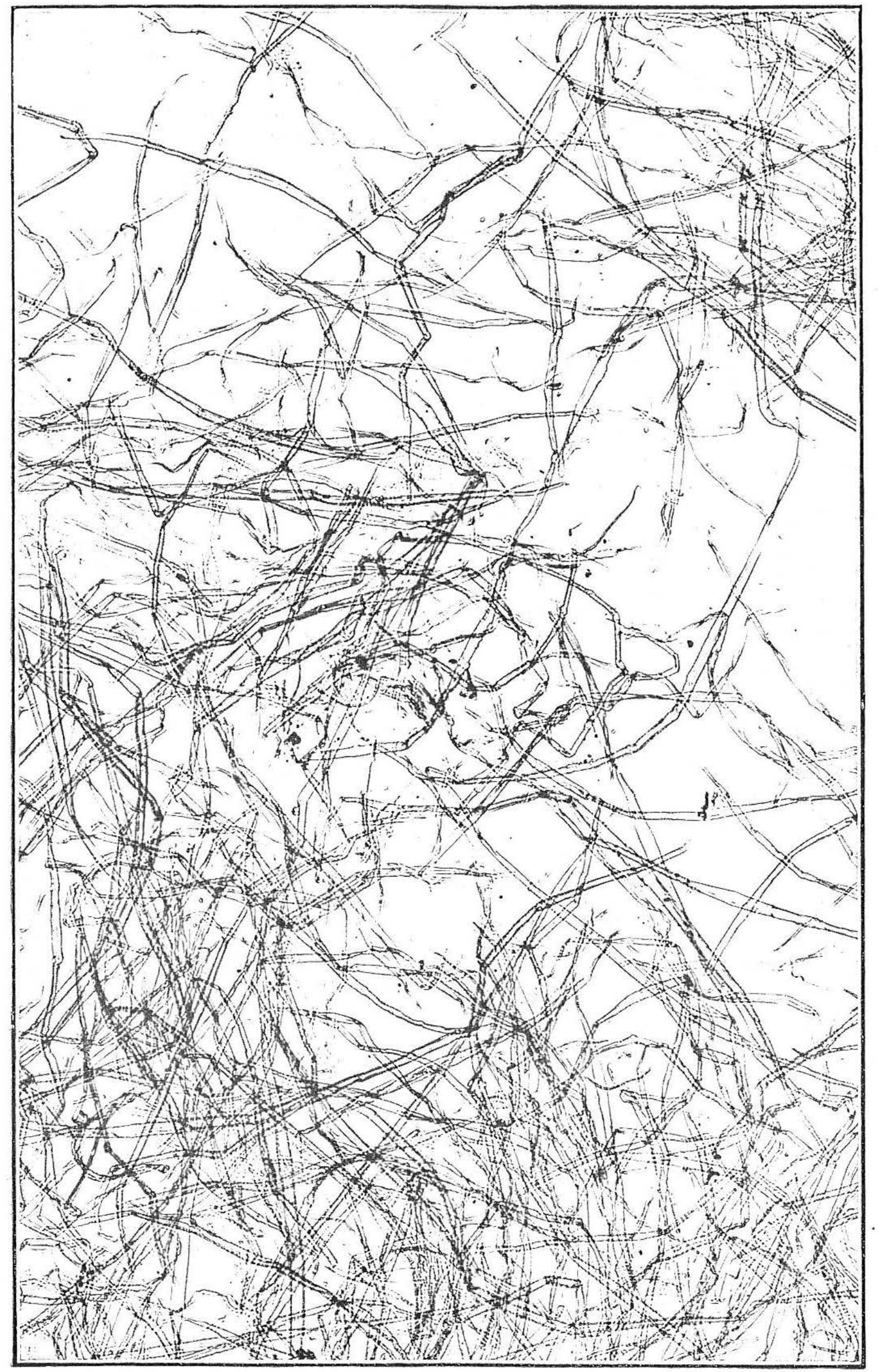

Fibers of an OVer-Cooked Pulp Produced With a Large amount of Caustic SODA. (COOK 4.) MAGNIFIED 65 DiAMETERS.

Purtial disintegration has taken place. The fibers are fragmentary and contorted with rather weak cell walls. The vessels with barely visible markings are on the point of being eliminated. 


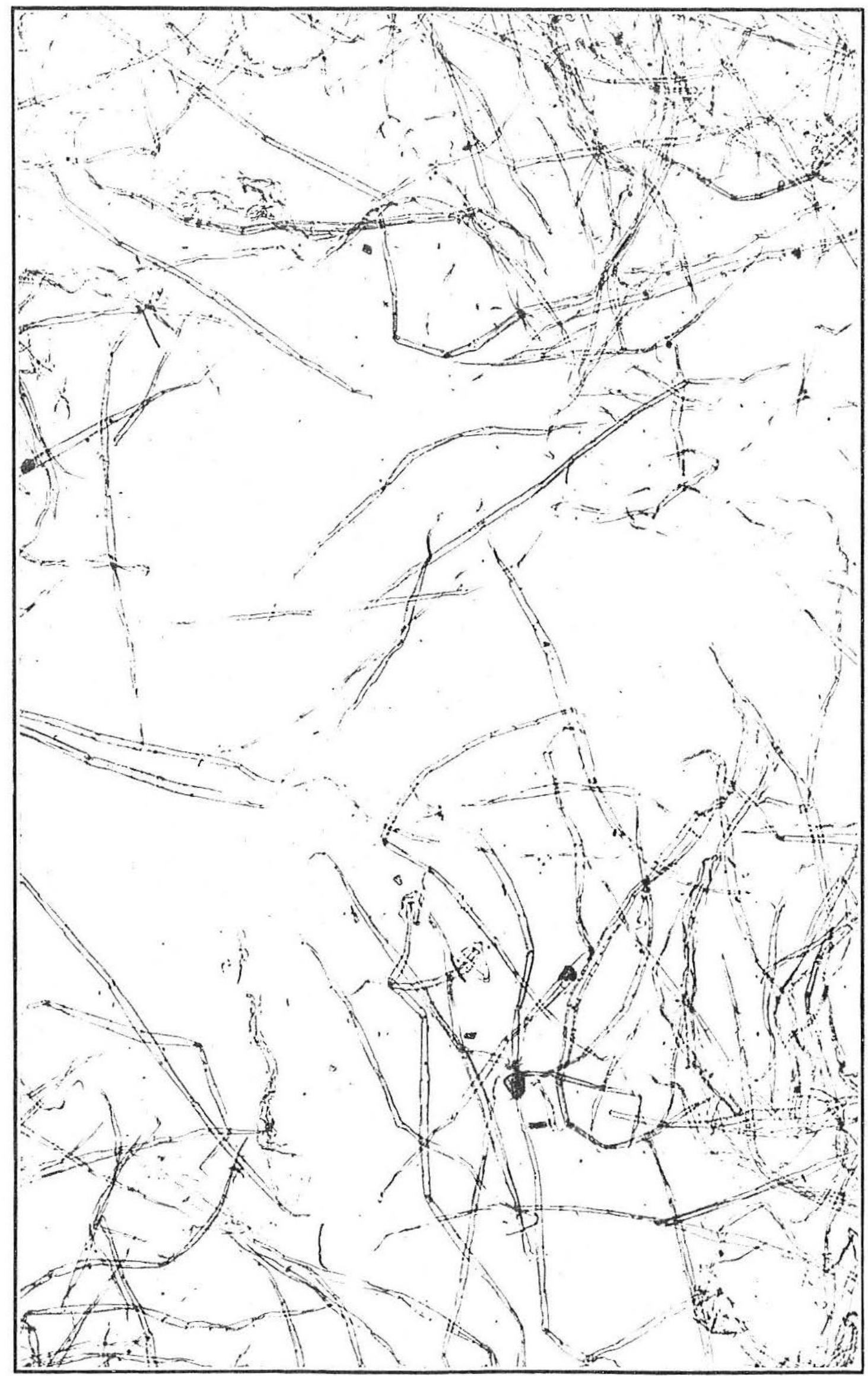

Fibers of an OVer-Cooked Pulp Produced with a High Concentration of Caustic SODA. (COOK 23.) MAGNIFIED 65 DiAMETERS.

The fibers are somewhat fragmentary, 


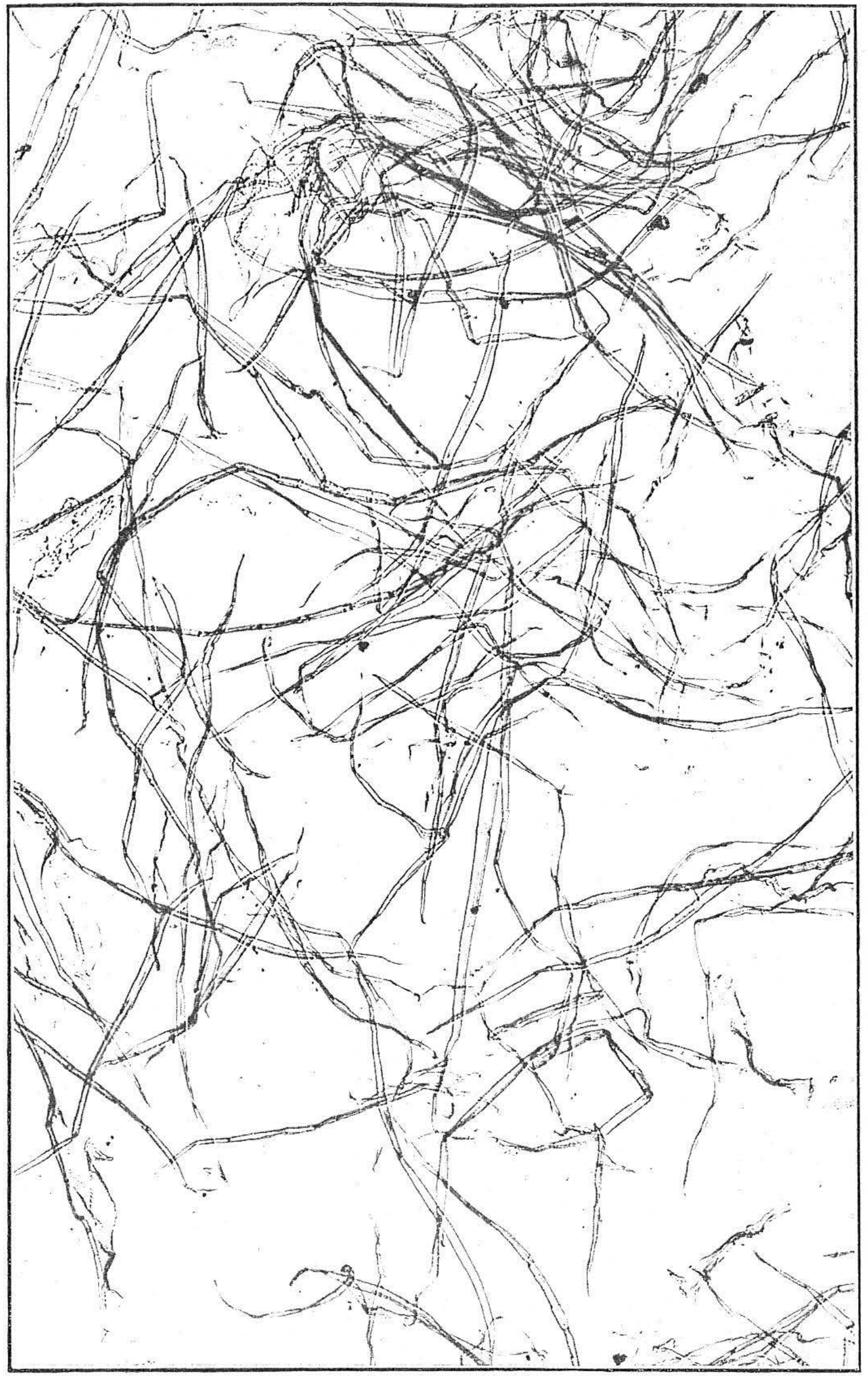

Fibers of a Well-Cooked Pulp Produced with a Medium amount of Caustic SOdA. (COOK 7.) MAGNiFIEd 65 Diameters.

This is a pulp of average good quality. Vessels are well defined. 


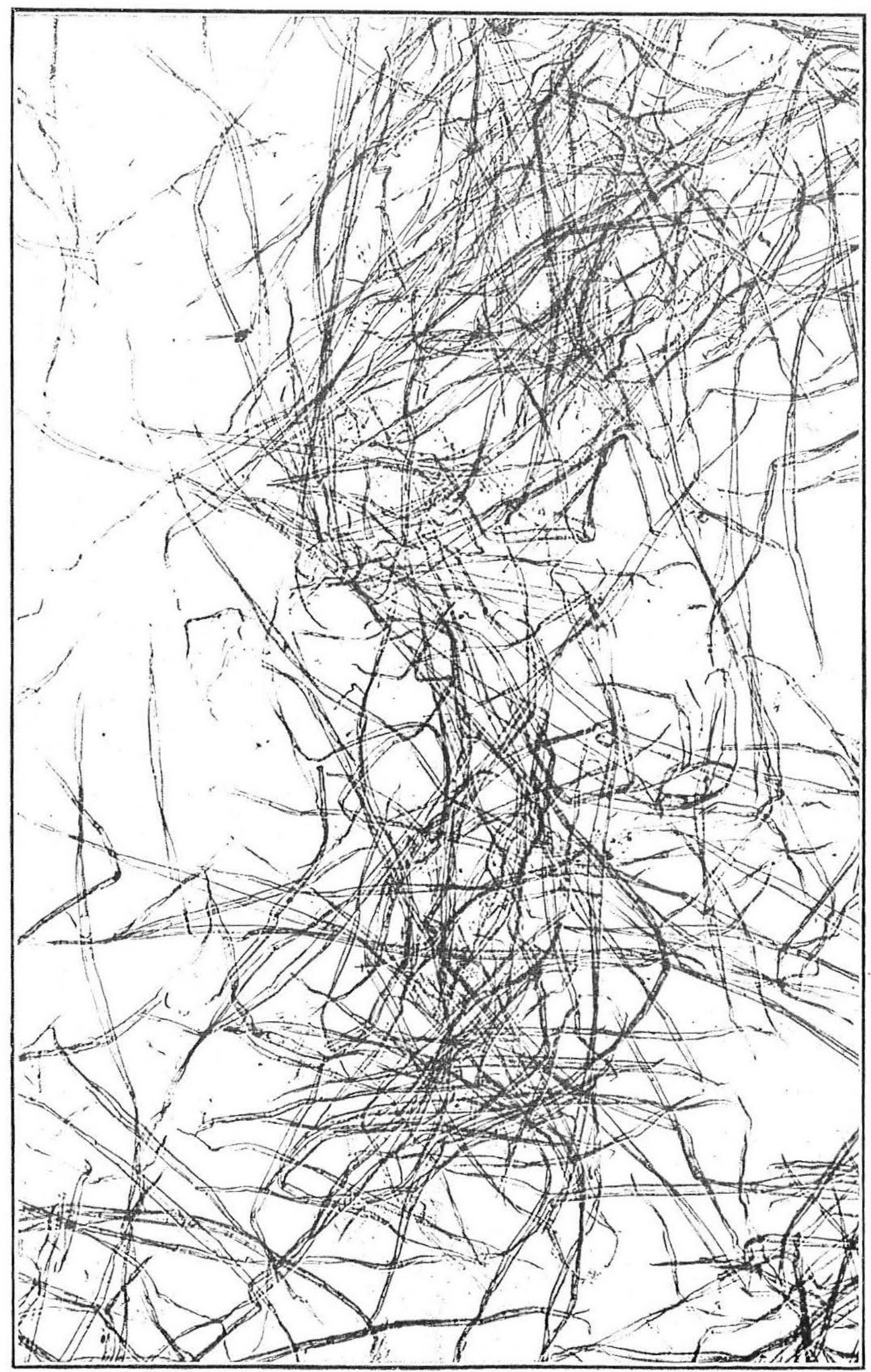

Fibers of a Well-Cooked Pulp Produced with a High Pressure of Cooking. (COOK 17.) MAGNIFIED 65 DiAMETERS. 


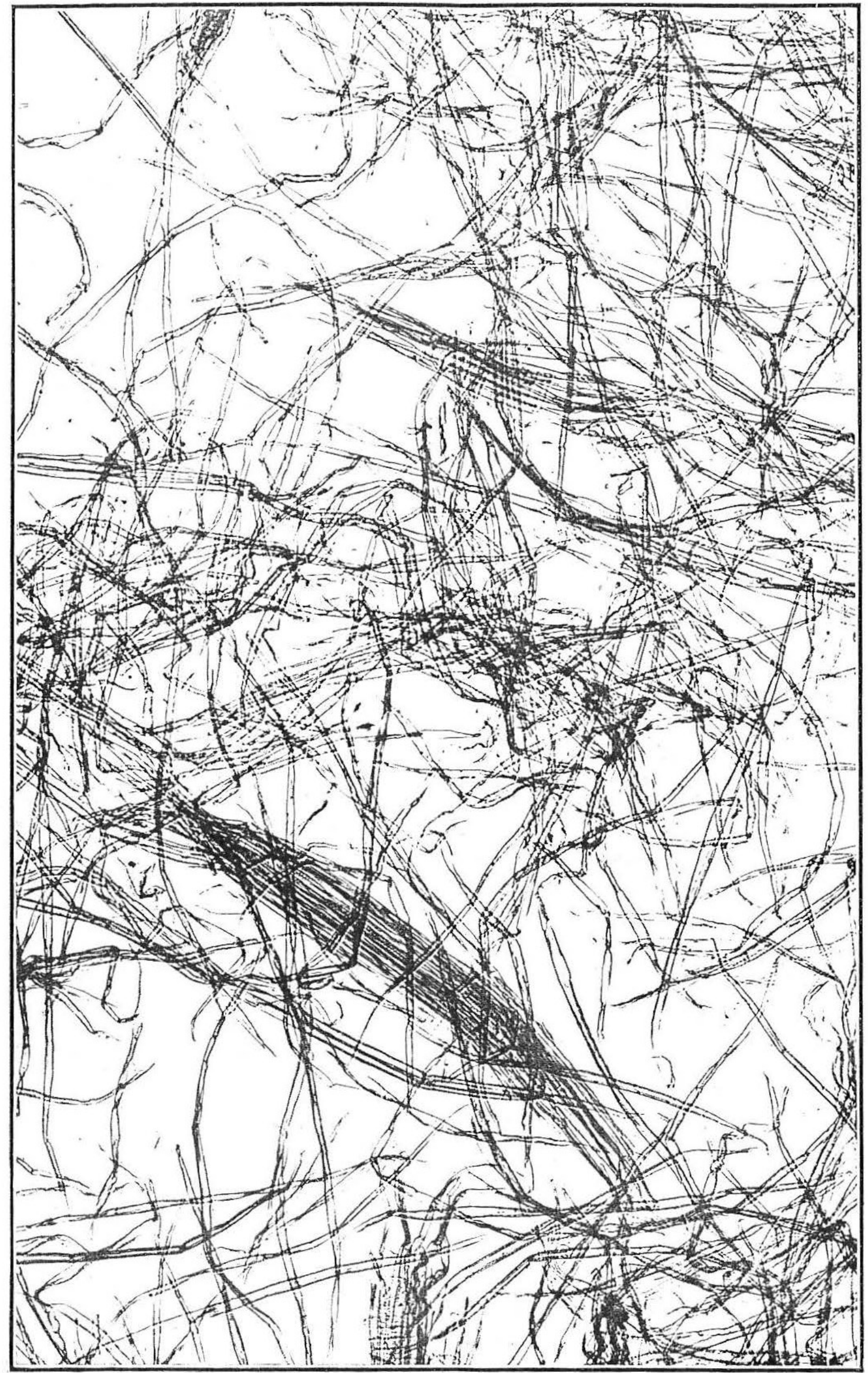

Fibers of AN Under-CoOKed Pulp Produced With a SHORT DURATION OF COOKING. (COOK 16.) MAGNIFIED 65 DIAMETERS.

Many shives, consisting of two or more unseparated fibers which parallel each other, are present. 


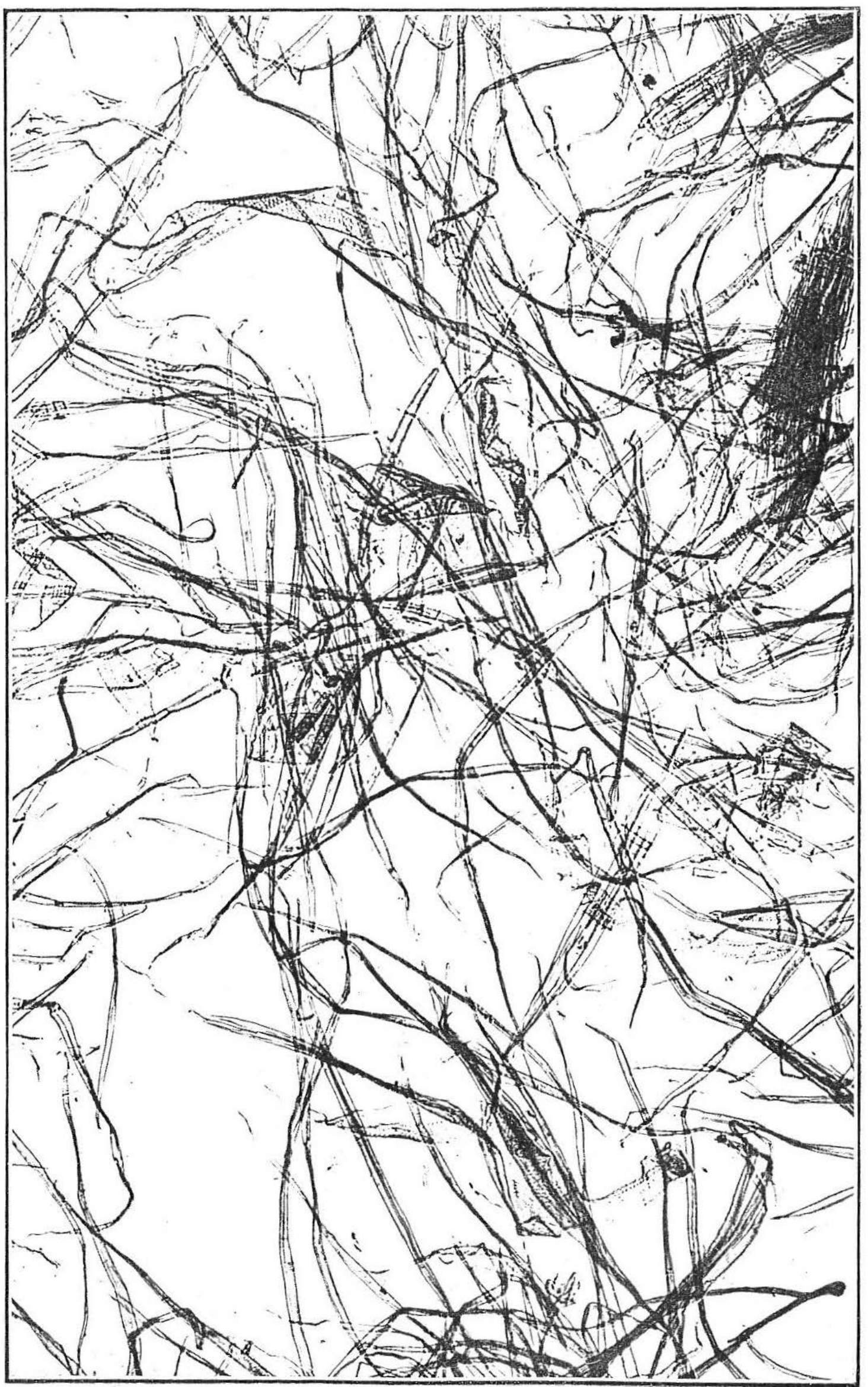

Fibers of an Under-CoOked Pulp Produced with a Small amount of Caustic SODA. (COOK 9.) MAGNIFIED 65 DIAMETERS.

Note the vessels with well-defined markings and the rily cells holding together a group of fibers constituting a shive. 
cooking conditions on the resultant condensations are shown in figure 17. Curves showing the initial volumes of digester liquors for two of the groups of tests are also included in the same figure.

In the tests employing various proportions of caustic soda, the amount of liquor at the start of cook varied directly with the amount of chemical, as shown by the straight-line curve. The condensation also increased rapidly as the amounts were increased. The downward turn in the heavy-line curve for the higher proportions of caustic is caused by the digester becoming filled and overflowing through the top relief during the final stages of cooking. However, the dotted
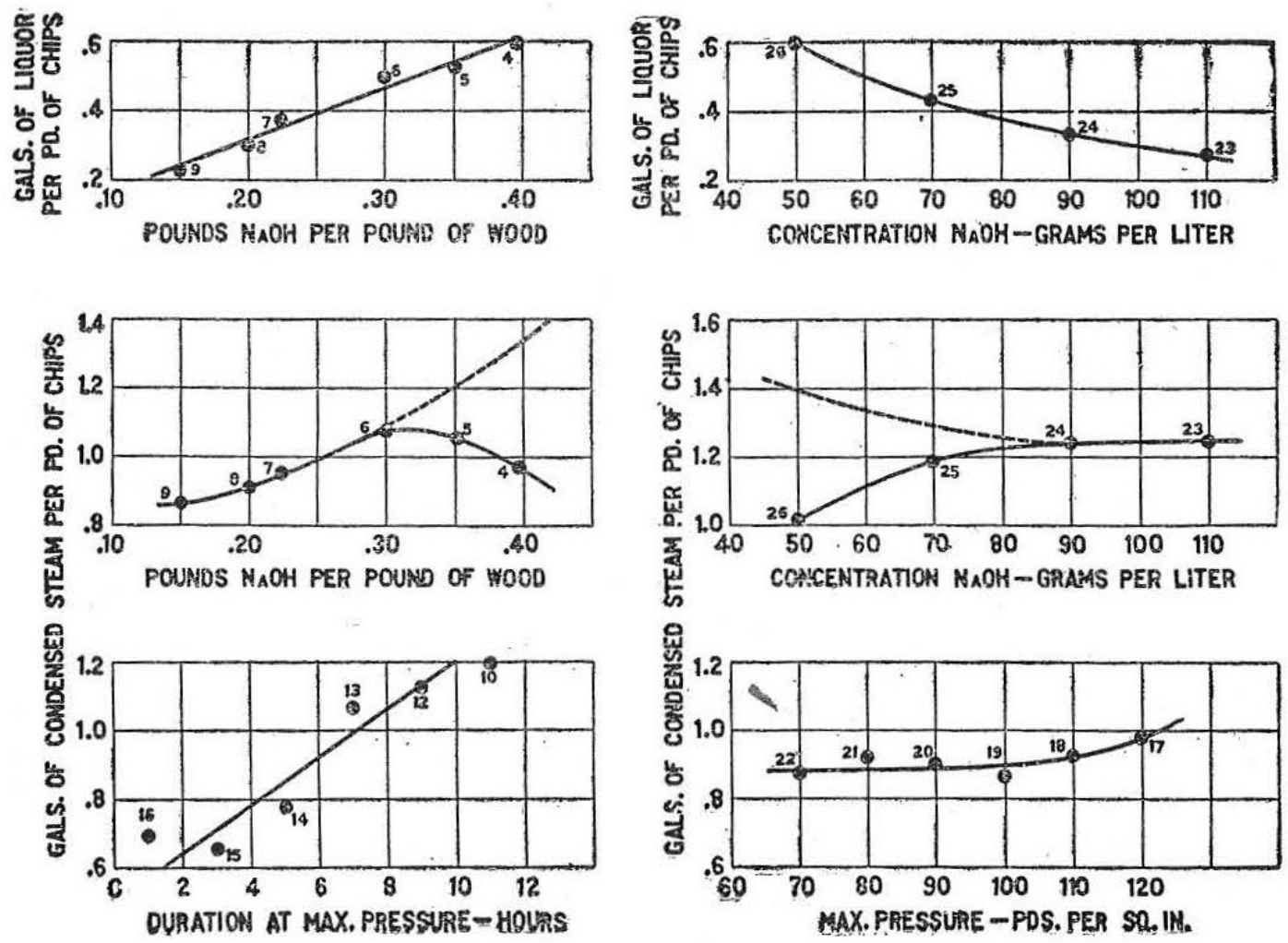

Fig. 17.-Effects of cooking conditions on initial volume of digester liquors and on condensation of steam.

line shows the corrected curve, taking the overflow into consideration. The rapid increase in the condensation is a natural consequence of increasing the amount of cooking liquor, which has a high specific heat.

In the tests employing various cooking periods the main influence on steam consumption was the heat lost by radiation, since the initial volumes of digester liquors were constant. The curve in figure 17 representing this effect has been drawn as a straight line to show only the general trend. It will be observed, however, that the platted points occur in two distinct groups. That the reaction between wood and caustic soda is of an exothermic or heat-generating nature may partly explain this arrangement. In the one group, representing the cooks of longer duration, the cooking reaction was $31091^{\circ}-$ Bull. $80-14-3$ 
practically completed before the end of the cooking period (see analogous curves in figs. 12 and 13). This would result in relatively higher amounts of condensation, since no heat of reaction would be generated during the later stages of cooking. ${ }^{1}$ The same explanation could apply to the cooks made at the higher pressures.

The influence of higher cooking pressures on steam consumption results from the greater amount of steam required to heat the digester and its contents to the higher temperatures and the greater loss of heat by radiation at such temperatures. The initial volumes of cooking liquor did not vary. The condensation curve indicates that this effect was comparatively small in the tests.

Like the tests varying the amount of caustic soda, those varying the initial concentration influence the steam consumption principally by the amount of liquor in the charge, which varies as shown by the true hyperbolic curve in figure 17. Hence, increasing the initial concentration decreased the condensation, as shown by the corrected curve in figure 17, which takes into account the overflow of the digester in cooks 25 and 26.

In considering these results from a commercial standpoint it should be kept in mind that the experimental apparatus was comparatively small. On this account the heat or steam required for raising the temperature of the digester and for replacing heat lost by radiation per unit of digester capacity was far greater than would be experienced in mill operation. Hence, much less steam per pound of chips would be required in commercial operations than is shown by these curves. The effects of increased duration of cooking and increased pressures especially would be much less pronounced, since with these radiation is the more important factor.

Aside from the direct cost of steam, the condensation is of importance in another way. The tests have shown that decreased initial concentrations, other cooking conditions being constant, result in less severe cooking. I I is to be expected that the decrease of concentration throughout the cooking period, due to condensation, also tends to minimize the cooking effects in a similar manner. ${ }^{2}$

The use of superheated steam in cooking, the installation of larger digesters, the insulation or lagging of digesters, and the use of the minimum volume of cooking liquors at the start of cook are means frequently employed by pulp mills to reduce the condensation.

1 The condensation curve (liquor in digester-gallons) in fig. 3, which is typical for most of the individual cooks in these experiments, also shows a greater rate of condensation at the end of the cook than at earlier periods except during the first hour when the pressure was being increased. This can be accounted for only by the fact that heat, other than from the steam alone, was supplied to the digester during the earlier stages of cooking. As the cooking reaction is most vigorous at the beginning, it seems probable that the heat supplied was heat of reaction.

2 It is evident that the effects obtained in the tests varying the initial concentrations are much less pronounced than would have been the case if the diluting effect of condensation had been absent. The autoclave tests, for which data are given in Table 15, afford fairly conclusive proof of this. 
CHEMICALS PER TON OF PULP.

The chemicals directly employed in the manufacture of soda pulp affect cost of production, in that the full amount of alkali charged to the digester can not be recovered, while the bleaching powder after being used is of no further value. The curves in figures 18 and 19, expressing the effects of the cooking conditions on the amounts of chemicals employed per ton of air-dry, bleached pulp, were derived from the experimental data as explained on page 48 , appendix. The amounts shown are less than those generally employed in commercial practice, for several reasons: (1) The yields of pulp are higher; (2) the losses on bleaching are less; (3) the amounts of chemical charged per pound of wood are less; and (4) the amounts of bleach required are less. Whether or not pulp mills can duplicate or approach these results, the general trend of the curves would not be affected.

SODA ASH.

The amounts of caustic soda and sodium carbonate charged to the digester in the several groups of tests have been calculated to show the equivalent amounts of commercial soda ash (58 per cent $\mathrm{Na}_{2} \mathrm{O}$ ) per ton of bleached pulp produced. (Fig. 18.) Increasing the amounts of
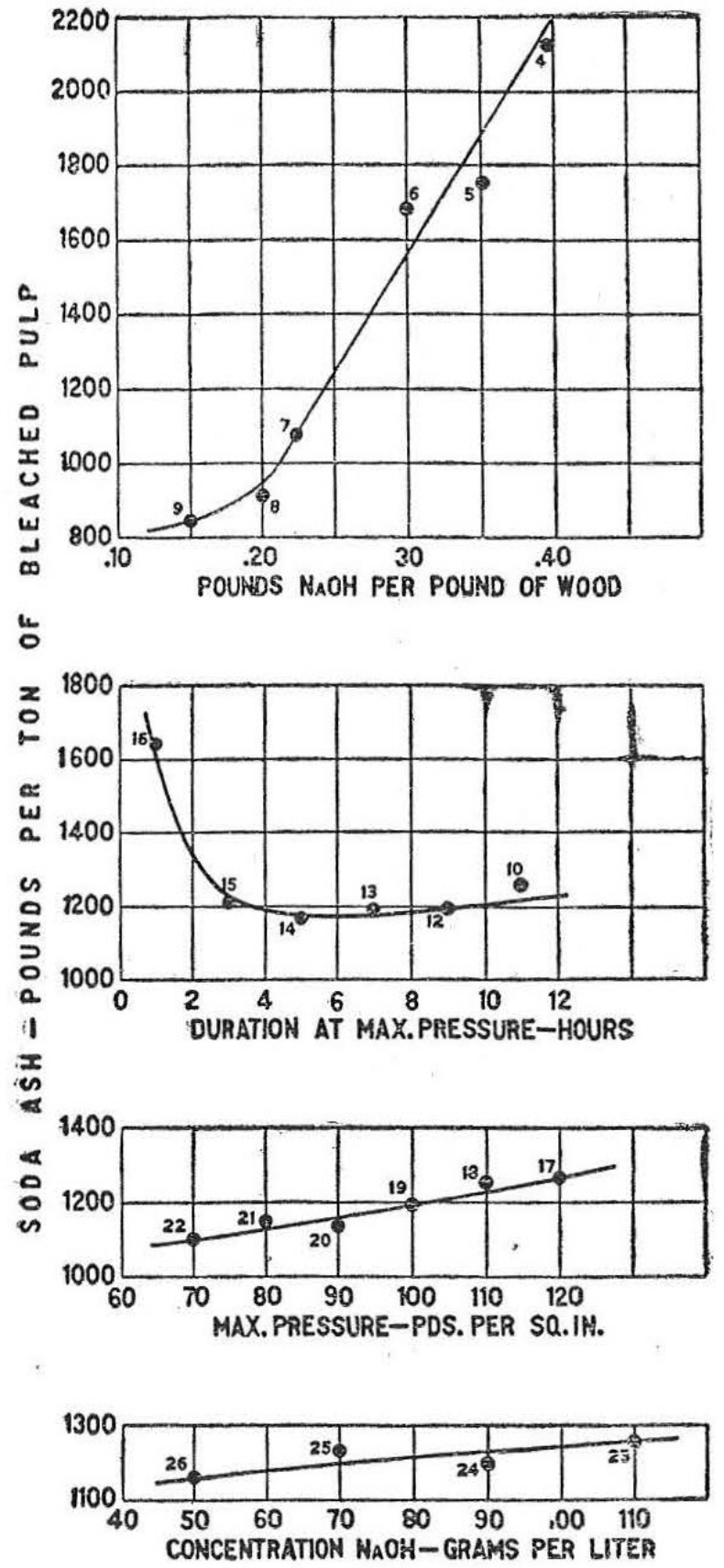

FIG. 18.-Effects of cooking conditions on amount of soda ash employed per ton of pulp. caustic soda charged per pound of wood obviously results in increasing amounts of soda ash per ton of pulp, and the decreased yields of pulp resulting from the more thorough cooking make the effect more pronounced. A bend is found in the curve at the point of maximum yield, since for amounts of caustic below this point the yields decrease rapidly and their influence on the amount of soda ash employed per ton of pulp becomes more apparent. 
When varying the durations and the pressures of cooking and the initial concentrations, the amounts of soda ash per ton of pulp were affected by yields alone, and the minimum amount is employed under conditions which give the maximum yields. Increased durations,

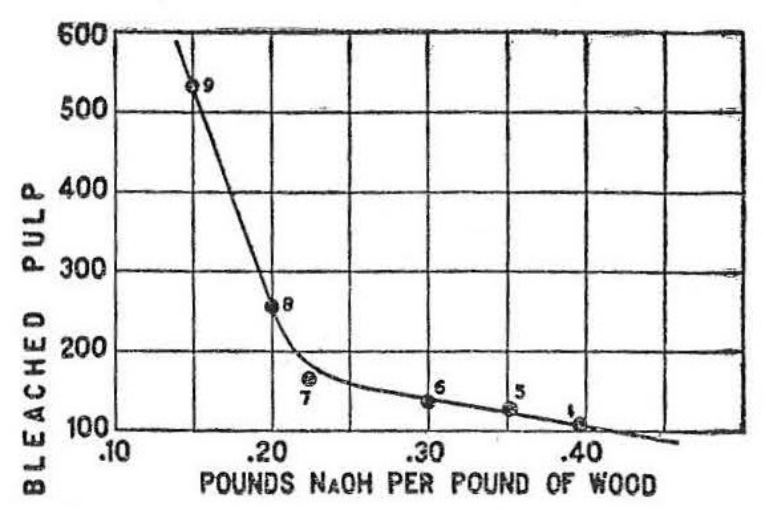

(c)
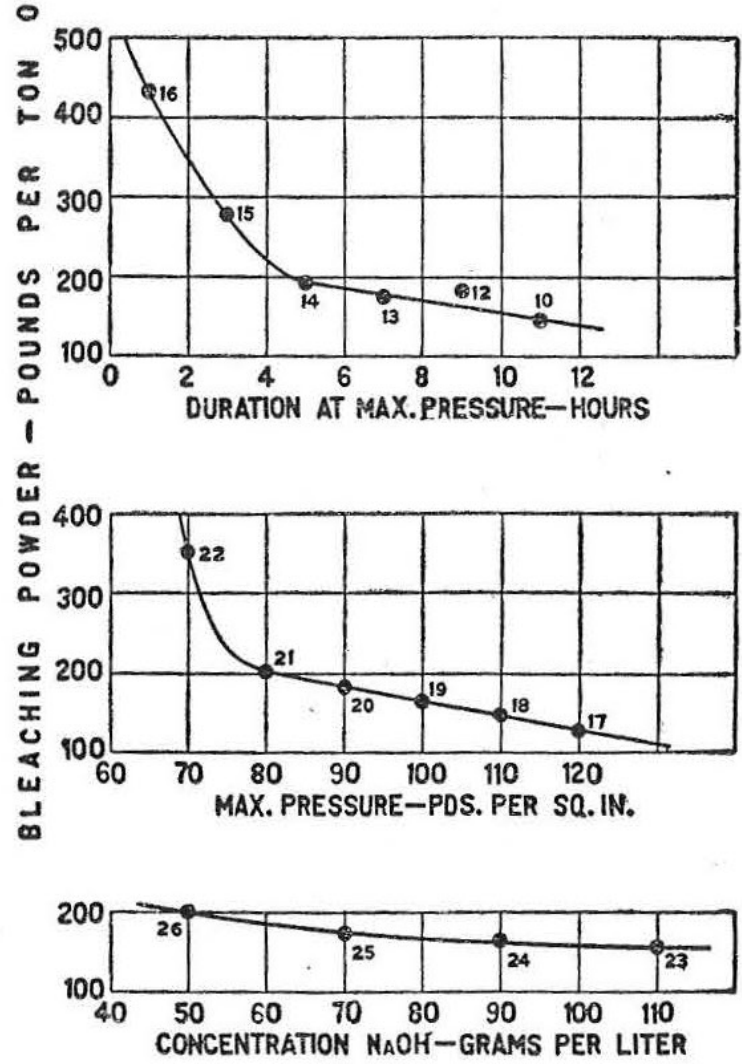

Fig. 19.-Effects of cooking conditions on amount of bleaching powder employed per ton of pulp. pressures, and concentrations afford decreased yields, and the amount of soda ash per ton of pulp consequently is increased. The platted point for cook 10 is not on the curve, due to the initial digester liquors for this cook having had about 3 per cent lower causticity than the other cooks in this group of tests. Lower causticities involve the use of a greater amount of soda ash for the same amount of caustic soda.

\section{BLEACHING POWDER.}

The curves in figure 19 show that increasing the amounts and concentrations of caustic soda and the durations and pressures of cooking result in all cases in decreasing the amounts of bleaching powder consumed.

Yields do not influence the calculations, since the consumption per ton of bleached pulp depends on the per cent of bleach required and the bleaching losses. The ordinates for the curves represent bleaching powder of 35 per cent available chlorine, and losses in making the bleaching solutions are disregarded.

\section{COMBINED COST OF WOOD AND CHEMICALS PER TON OF PULP.}

The curves in figure 20 show costs for certain items in producing a ton of bleached pulp (2,000 pounds air-dry basis) as influenced by variations in the cooking conditions. Curves marked A represent cost of wood alone; curves B, cost of wood and soda ash; and curves C, 
cost of wood, soda ash, and bleaching powder. The vertical distances between curves $\mathrm{A}$ and $\mathrm{B}$ represent cost of soda ash alone, and those between curves $\mathrm{B}$ and $\mathrm{C}$ represent cost of bleaching powder alone.

The cost values were obtained by calculations from the amounts of wood, soda ash, and bleaching powder consumed, based on the experimental results. ${ }^{1}$ A 90 per cent recovery of the cooking chemicals charged to the digester was assumed in determining the amounts
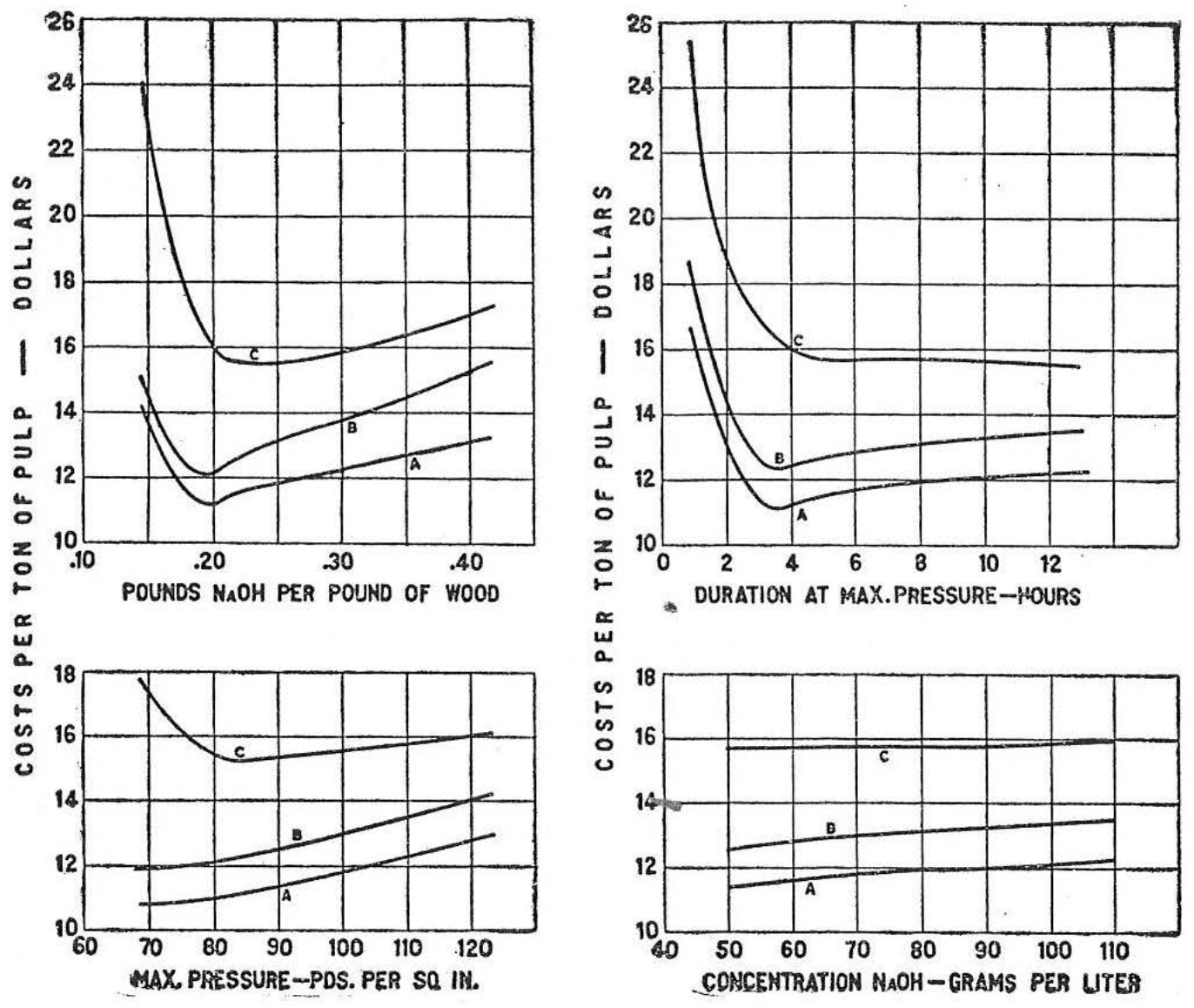

FrG. 20.-Effects of cooking conditions on cost items per ton of pulp. A, wood; B, wood and soda ash; and C, wood, soda ash, and bleaching powder.

of soda ash consumed or lost per ton of pulp. The basic units for costs are assumed average values as follows:

Wood, $\$ 9$ per solid cord (100 cu. ft.); soda ash (58 per cent $\mathrm{Na}_{2} \mathrm{O}$ ), $\$ 1$ per 100 pounds; bleaching powder (35 per cent available chlorine), $\$ 1.55$ per 100 pounds. $^{2}$ The bone-dry weight of aspen wood is taken as 26.68 pounds per cubic foot of clear wood, green volume.

1 These amounts were calculated by interpolating from the yield curves (fig. 4), the loss on bleaching curves (fig. 10), and thecurves for soda ash and bleaching powder employed per ton of pulp (figs. 18 and 19), and not from actual test data. On this account platted points have been omitted.

2 Reasonable maximum, average, and minimum values for a "solid cord" of aspen f. o. b. mill are $\$ 11$, $\$ 9$, and $\$ 6$, as determined from statistical reports received from a number of mills. Correspondence with pulp manufacturers brought the information that reasonable maximum, average, and minimum unit costs as defined above may be assumed with a fair degree of accuracy as follows: For soda ash, $\$ 1.20, \$ 1$, and $\$ 0.85$; for bleaching powder, $\$ 2.05, \$ 1.55$, and $\$ 1.10$. These values do not depend upon market fluctuations alone, but vary through the range given, due largely to differences in freight charges 1or mills in different localities. The actual selling price of " 58 per cent" soda ash is $10 / 48$ greater than the manufacturer's or market quotations, since the latter are based on the old standard of " 48 per cent" goda ash. 
With increasing amounts of caustic soda in the digester charges the cost due to all three factors is decreased until the point of maximum yield of good pulp is attained, after which the total costs increase, due to the increasing amounts of wood and of soda ash consumed. The decreasing cost of bleaching powder only partially offsets the increase due to the other two factors.

With increasing durations the effect is practically the same, so far as wood alone is concerned, except that the increase in its cost for higher durations is not so pronounced as with increasing the amounts of caustic soda. The soda-ash costs alone are practically constant, and hence increase the wood costs by a constant amount. However, as the durations increase, the bleaching-powder costs decreased sufficiently to overcome the effect of increasing wood costs. After the minimum duration for successful cooking (as determined by yields) has been exceeded, the decrease in total cost is very small, and would not be sufficient to offset increased costs incident to the time element discussed previously.

For variations in the pressures of cooking, the influence of bleachingpowder costs is especially marked. The minimum costs due to wood and soda ash result from the use of the lower pressures. When bleaching is considered, the minimum cost is obtained by using medium pressures, although the increases for the higher pressures are very small.

Combined costs for the three factors are practically unaffected by variations in the initial concentrations, but if bleaching is omitted the costs of wood and soda ash are larger with the higher concentrations.

All of the diagrams show that of the three cost factors considered, wood is of the most importance and that bleaching powder is more influential than soda ash in determining total costs. Increases in costs of wood and soda ash with increasing severity of cooking are, in all cases, offset, to a greater or less extent, by decreases in bleachingpowder costs. If maximum or minimum values ${ }^{1}$ had been used for either wood, soda ash, or bleaching powder, instead of the average value, or if a different percentage recovery for the soda ash had been assumed, the general effects would not be changed, although they might become more or less pronounced.

\section{SUMMARY. ${ }^{2}$}

(1) The amount of caustic soda per pound of wood, the duration of cooking, the pressure or temperature of cooking, and the concentration of the cooking chemicals employed in the production of soda

\footnotetext{
1 See footnote, p. 37.

2 The more general statements in the summary will be found to coincide in a greater or less degree with previously existing opinions, a fact not surprising when it is remembered that the soda process has been carried on for half a century. On the other hand, satisfactory evidence and data substantiating these opinions have not been available. The present investigation affords such information, as well as a basis for more specific conclusions.
} 
pulp influence the yield and properties of the pulp by influencing the severity of the cooking reactions.

(2) Severity of cooking is an effect mainly of the amount of caustic soda consumed per unit of wood. Increasing the amount or concentration of the chemical or the pressure of cooking produces a quicker reaction and hence one more complete in a given length of time. Increasing the duration results in a more complete reaction because of the longer time allowed for the available caustic soda to be consumed.

(3) Greater severity of cooking is accompanied by a decrease in the yield of crude pulp, and usually of screened pulp. If screenings are present in considerable quantity (due to incomplete cooking), more thorough cooking increases the yield of screened pulp.

(4) The properties of the pulp are influenced by greater severity of cooking as follows:

(a) Shives are decreased in number or eliminated.

(b) Bleaching is rendered more easy and the loss on bleaching becomes less.

(c) The strength may either decrease or increase, depending upon which cooking condition is varied and the degree of variation.

(d) The color of the unbleached pulp becomes lighter within certain limits, beyond which it may, under certain conditions, become darker.

(5) A good indication of the severity of cooking is the appearance of the individual fibers when examined under the microscope.

(6) The decreased yields resulting from more severe cooking result in a greater cost of wood and soda ash per ton of pulp. As a rule, the smaller cost of bleaching powder incident to the more easily bleached pulp produced by thorough cooking only partially offsets the greater cost of wood and soda ash.

(7) While the amount of bleach required decreases with increasing severity of cooking, a point is soon reached where the decrease in bleach required is not commensurate with the decrease in yields.

(8) Increasing the initial amount of digester liquor increases the condensation and steam consumption (and hence the cost) because of the greater volume to be heated; increasing either the duration or pressure has a similar effect because of the greater losses of heat by radiation.

(9) Yields (bone-dry basis) of well-separated unbleached pulps as high as 56 or 58 pounds per 100 pounds of wood can be obtained from aspen if the wood is of the best quality. Yields of from 54 to 55 per cent were obtained which required only from 10 to 11 per cent of bleach. The variation in yields obtained by changing the cooking: conditions was from 46 to 58 pounds per 10 pounds of wood charged, or about 26 per cent based on the lowest yield.

(10) Minimum total durations of from 3 to 4 hours may be successfully applied to the cooking of aspen for bleaching pulps, provided the other cooking conditions are properly maintained. 
(11) Aspen may be successfully cooked with a minimum of from 20 to 25 pounds of caustic soda charged per 100 pounds of wood. The amount of this chemical actually consumed in the production of well-cooked bleaching pulps varies from 18 to 24 pounds per 100 pounds of wood.

\section{PRACTICAL VALUE OF RESULTS.}

The experiments discussed in this bulletin have shown in detail the effects of certain cooking conditions on the yields and properties of the resultant pulp, on the efficiency of the cooking chemicals, and on various items affecting costs of production. From a study of these results it should be possible for a mill operator so to regulate the cooking process as to secure the largest possible yield of pulp of the desired quality at a minimum cost for chemicals, fuel, labor, and overhead charges in so far as the operation is affected by the cooking conditions considered.

The clear, sound wood used in the experiments afforded yields of good pulp from 10 to 25 per cent higher than the better run of the yields reported by pulp mills. Moreover, some of these experimental yields were obtained with shorter cooking periods and less chemicals than are employed commercially. Although the laboratory results may not be equaled in mill practice, the possibility of greatly increased efficiency in the process of converting wood into soda pulp is indicated.

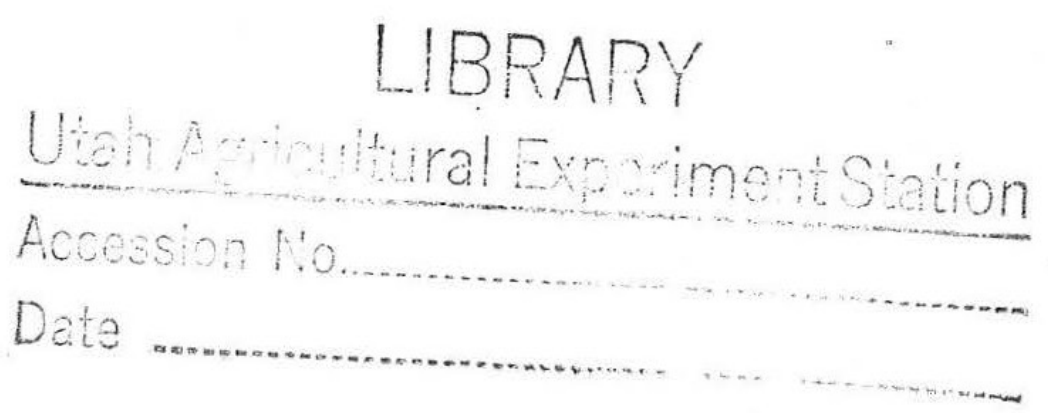




\section{APPENDIX.}

\section{ASPEN AS A RAW MATERIAL FOR PAPER PULP.}

\section{DISTRIBUTION AND CHARACTERISTICS OF THE TREE. 1}

Aspen (Populus tremuloides Michx.), or quaking aspen, as it is sometimes called, is one of the most widely distributed and best-known American trees. Together with the closely related European species, Populus tremula Linn., from which paper pulp of excellent quality is also prepared, it encircles almost the entire globe. In America aspen extends from Labrador to Alaska and southward to Tennessee and Arizona. Yet it occurs scatteringly, and pure stands of any extent are comparatively rare. For this reason it is not possible to give even approximately the present total stand. In the western forests, notably those of Utah and western Colorado, there are vast quantities which will doubtless be an important source of future supply. In the past New England furnished most of the aspen pulpwood, and although the supply there is badly depleted, considerable quantities yet remain in certain regions, notably in northern Maine. ${ }^{2}$

Aspen is a very rapid grower and quickly covers burned or logged-over lands. However, it is comparatively short-lived, and the larger trees suffer severely from fire, windshake, insects, and fungi. In fact, aspen is defective from decay to a greater extent than any other commonly used pulpwood, except perhaps balsam fir. The trees ordinarily used for pulpwood are from 5 to 14 inches in diameter. If grown in close stands, the trunks are fairly free from knots and limbs. Logging is comparatively easy.

Aspen wood after cutting is also susceptible to fungous attack unless kept very dry. It is particularly perishable in contact with the soil: The ability of the wood to season rapidly, especially after being barked, is of much advantage. Nevertheless, mills which store a year's supply or more in open yards undoubtedly have a large proportion of their older wood affected. The general opinion is that "old wood" produces inferior pulp and lower yields.

\section{PROPERTIES AND STRUCTURE OF THE WOOD.}

The wood of aspen is soft, light in weight, not strong, and close grained, but with numerous minute, open ducts. The medullary rays are very thin and hardly distinguishable with the naked eye. The color is light brown, the sapwood almost white and very thick, often representing 25 to 30 layers of annual growth. In the green or freshly seasoned material, however, the difference between heartwood and sapwood is in most cases scarcely appreciable. A cubic foot of air-dried wood usually weighs from 25 to 30 pounds.

\footnotetext{
${ }^{1}$ A more complete discussion of the silvical characteristics of aspen is given in Forest Service Bulletin 93, The Aspens; Their Growth and Management, by W. G. Weigle and E. H. Frothingham, 1911.

2 Forest Service Bulletin 93, pp. 13 and 17, 1911.
} 
Determinations ${ }^{1}$ made on sound sticks of aspen varying from 8 to 10 inches in diameter showed about 62.8 per cent of cellulose. Müller, quoted by Clapperton, ${ }^{2}$ gives the following analysis ${ }^{3}$ for the poplars:

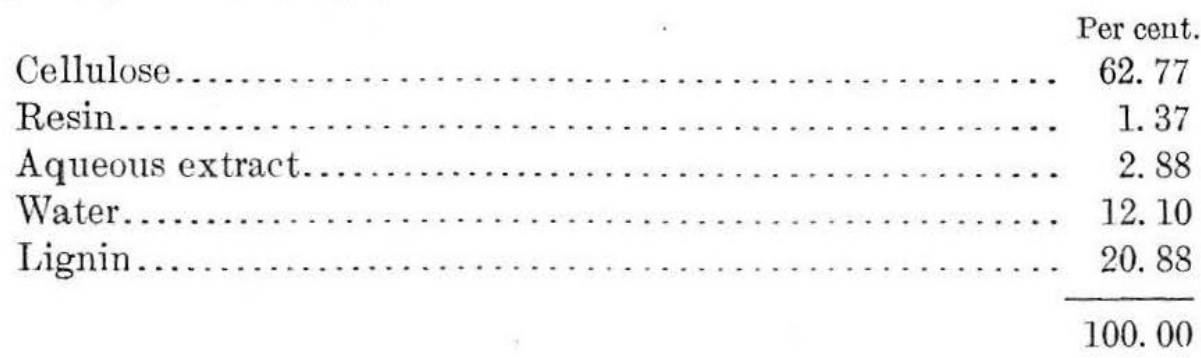

Since bleached pulp is very nearly pure cellulose, the maximum yield obtainable could not be appreciably higher than 63 per cent.

Aspen wood is made up of three types of structural elements-fibers, vessels, and parenchymatous tissue. The latter comprises the medullary ray cells and the rather scantily developed parenchyma cells at the end of the year's growth. The structure is shown in Plates VIII and IX. In Plate VIII, figure 1, the long tubes running the length of the picture are the vessels; cross sections of the medullary rays can be seen scattered among the fibers as dark vertical "plates," one cell in width and several in height. The ray cells are characterized by exceedingly thin walls, and when the wood is cooked for pulp these cells readily dissolve. The vessels are more resistant to chemical attack than the parenchymatous tissue, and the fibers, because of their relatively thick walls, are least affected by the cooking process. It is also possible that the cellulose constituting the fiber walls is more resistant than the cellulose of the other elements. In Plate IX, figure 2, the middle lamella or intercellular substance appears as a black line between the adjacent walls of the elements. This is dissolved in the process of cooking for paper pulp.

Aspen fibers are comparatively short. Examples of long-fibered woods used in paper making are spruce, hemlock, and balsam fir, and of medium-length ones tulip tree, sweet gum, and cottonwood. The actual dimensions of aspen fibers vary a great deal with the tree and the part of the tree from which secured. Forest Service measurements ${ }^{4}$ of a large number of fibers of aspen wood showed a range of from about 0.5 to $1.6 \mathrm{~mm}$. in length and an average length of $1.0 \mathrm{~mm} .{ }^{5}$

\section{PULPWOOD CONSUMED.}

At the present time soda, sulphite, sulphate, and mechanical pulps are made from aspen and other poplars, but the soda process has always used these woods in by far the greater amounts, and they continue to form the chief pulpwood supply for this process. The other processes of pulp making have been applied to the poplars within recent years only, although it was known 20 or 30 years ago that they could be ground for mechanical pulp and could be reduced without difficulty by the sulphite process to an easy-bleaching pulp. The properties of the wood and the yields and qualities of the pulp made from it, combined with the proximity of an adequate supply and its relatively low cost, made this the best wood obtainable for the manufacture of soft, easy-bleaching soda pulp.

1 Forest Service Bulletin 93, p. 7, 1911.

2 Practical Papermaking, p. 43, 1907.

3 This analysis makes no mention of the ash. According to Sargent (Tenth U. S. Census Rept., Vol. IX) the ash in aspen varies from 0.31 to 0.76 per cent, with an average of 0.55 per cent, of the air-dry wood. See this report also for further data on the chemical composition and properties of aspen.

1 Forest Service Bulletin 93, p. 7, 1911.

5 One millimeter is equivalent to approximately one twenty-fifth of an inch. 
TABLE 5.-Consumption of poplar pulpwood and of all pulpwoods in the United States for years 1899 and 1905 to 1910, inclusive.

\begin{tabular}{|c|c|c|c|c|c|c|}
\hline Year and process. & $\begin{array}{c}\text { Domestic } \\
\text { poplar. }\end{array}$ & $\begin{array}{c}\text { Imported } \\
\text { poplar. }\end{array}$ & $\begin{array}{l}\text { Total } \\
\text { poplar. }\end{array}$ & $\begin{array}{l}\text { All pulp- } \\
\text { woods. }\end{array}$ & $\begin{array}{l}\text { Ratio } \\
\text { domestic } \\
\text { poplar } \\
\text { to total } \\
\text { poplar. }\end{array}$ & $\begin{array}{l}\text { Ratio } \\
\text { total } \\
\text { poplar } \\
\text { to all } \\
\text { pulp- } \\
\text { woods. }\end{array}$ \\
\hline 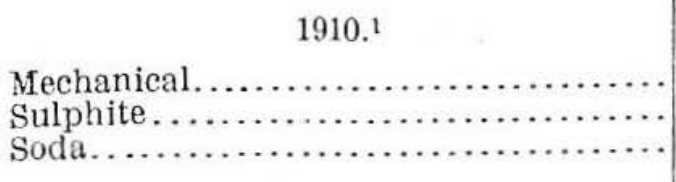 & $\begin{array}{r}\text { Cords. } \\
11,613 \\
2703 \\
303,401 \\
\end{array}$ & $\begin{array}{r}\text { Cords. } \\
1,834 \\
43,525 \\
\end{array}$ & $\begin{array}{r}\text { Cords. } \\
13,447 \\
2703 \\
346,926 \\
\end{array}$ & $\begin{array}{r}\text { Cords. } \\
1,180,598 \\
32,257,881 \\
6.55,827\end{array}$ & $\begin{array}{r}\text { Per cent. } \\
86.4 \\
100.0 \\
87.5\end{array}$ & $\begin{array}{r}\text { Percent. } \\
1.1 \\
.03 \\
53.0\end{array}$ \\
\hline & 315,717 & 45,359 & 361,076 & $4,094,306$ & 87.4 & 8.8 \\
\hline 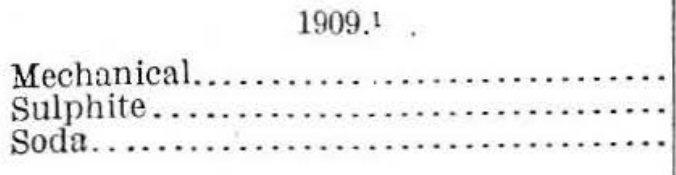 & $\begin{array}{r}17,905 \\
2,930 \\
282,041 \\
\end{array}$ & \begin{tabular}{r}
3,025 \\
\hdashline 22,597 \\
\end{tabular} & $\begin{array}{r}20,930 \\
2,930 \\
304,638 \\
\end{array}$ & $\begin{array}{r}1,246,121 \\
42,183,984 \\
571,502 \\
\end{array}$ & $\begin{array}{r}85.6 \\
100.0 \\
92.6 \\
\end{array}$ & $\begin{array}{r}1.7 \\
.1 \\
53.3\end{array}$ \\
\hline & 302,876 & 25,622 & 328,498 & $4,001,607$ & 92.2 & 8.2 \\
\hline 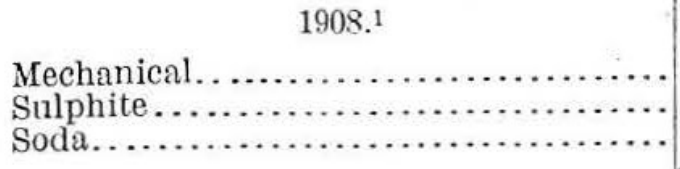 & $\begin{array}{r}16,734 \\
3,734 \\
259,096\end{array}$ & $\begin{array}{r}2,168 \\
3,023 \\
17,462 \\
\end{array}$ & $\begin{array}{r}18,902 \\
6,757 \\
276,558\end{array}$ & $\begin{array}{r}1,117,428 \\
1,739,282 \\
490,243 \\
\end{array}$ & $\begin{array}{l}88.0 \\
55.3 \\
93.6 \\
\end{array}$ & $\begin{array}{r}1.7 \\
.4 \\
56.4 \\
\end{array}$ \\
\hline & 279,564 & 22,653 & 302,217 & $3,346,953$ & 92.5 & 9.0 \\
\hline 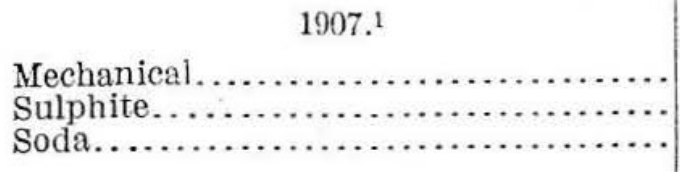 & $\begin{array}{r}16,903 \\
1,536 \\
333,703\end{array}$ & $\begin{array}{r}2,620 \\
17,178\end{array}$ & $\begin{array}{r}19,523 \\
1,536 \\
350,881\end{array}$ & $\begin{array}{r}1,361,302 \\
2,059,496 \\
541,862\end{array}$ & $\begin{array}{r}86.5 \\
100.0 \\
95.0\end{array}$ & $\begin{array}{r}1.4 \\
.1 \\
64.7\end{array}$ \\
\hline & 352,142 & 19,798 & 371,940 & $3,962,660$ & 94.7 & 9.4 \\
\hline 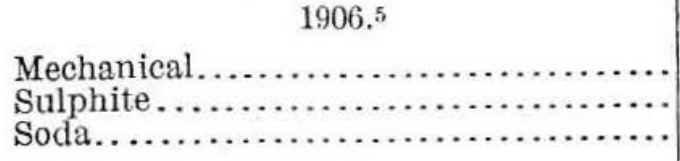 & $\begin{array}{r}10,475 \\
\dddot{300,} \dddot{4} \ddot{4} \overline{5}\end{array}$ & $\begin{array}{r}2,129 \\
\hdashline 15,421\end{array}$ & $\begin{array}{r}12,604 \\
315,866\end{array}$ & $\begin{array}{r}1,197,780 \\
1,958,619 \\
504,777\end{array}$ & $\begin{array}{l}82.8 \\
\dddot{95.1}\end{array}$ & $\begin{array}{r}1.1 \\
.0 \\
56.5\end{array}$ \\
\hline & 310,920 & 17,550 & 328,470 & $3,661,176$ & 94.6 & 9.0 \\
\hline 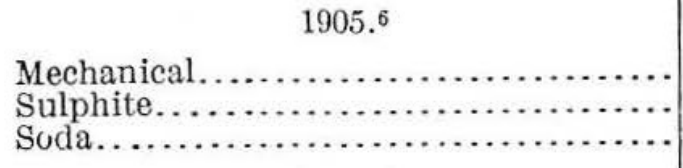 & $\begin{array}{r}8,592 \\
290,583 \\
\end{array}$ & $\begin{array}{r}2,800 \\
20,083 \\
\end{array}$ & $\begin{array}{r}11,392 \\
310,666\end{array}$ & $\begin{array}{r}1,096,794 \\
1,630,393 \\
464,936\end{array}$ & $\begin{array}{c}75.4 \\
93.5\end{array}$ & $\begin{array}{r}1.0 \\
.0 \\
66.8\end{array}$ \\
\hline & 299,175 & 22,883 & 322,058 & $3,192,123$ & 92.9 & 10.1 \\
\hline $\begin{array}{c}1899 .{ }^{7} \\
\text { Total................. }\end{array}$ & 8236,820 & 820,133 & \& 256,953 & $1,986,310$ & 92.3 & 12.9 \\
\hline
\end{tabular}

1 Bureau of the Census Circulars, Forest Products No. 1, Pulpwood Consumption (for respective years).

2 Includes 78 cords reduced by the sulphate process.

3 Includes 10,188 cords reduced by the sulphate process.

1 Includes 38,000 cords reduced by the sulphate process.

- Forest Service Circular 120, Consumption of Pulpwood in 1906.

6 Forest Service Circular 44, Wood used for Pulp in 1905.

7 Twelfth Census Bulletin 99, Manufactures: Paper and Pulp, Sept. 30, 1901.

${ }^{8}$ Used exclusively by the soda process. 
TABLE 6.-Cost of poplar pulpwood and of all pulpwoods at United States mills in 1907, 1908, and 1909.1

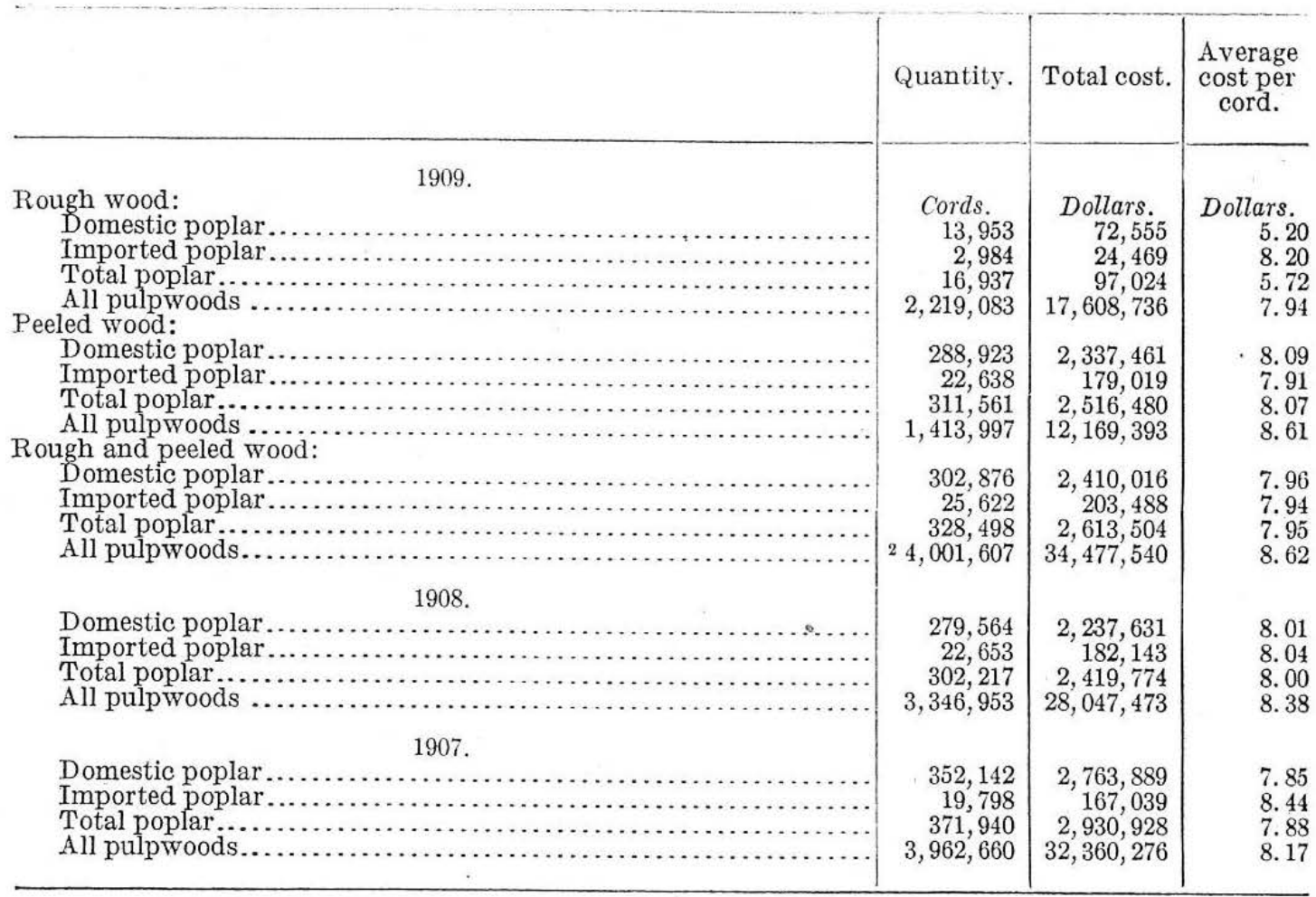

1 Bureau of the Census Circulars, Forest Products No. 1, Pulpwood Consumption (ior respective years). Prices quoted are based on $f$. o b. mill deliveries.

2 Includes 368,527 cords of rossed wood at an average cost of $\$ 12.75$ per cord.

While there are no statistics of the consumption of aspen pulpwood alone, the Census figures ${ }^{1}$ for the consumption of "poplar" are of interest. The woods grouped under this name consist of several species of the true poplars, of which aspen is by far the most important, and doubtless include also a small amount of "yellow poplar" or tulip tree (Liriodendron tulipifera Linn.). The poplars collectively stand third in the amount cut for pulpwood, being exceeded only by spruce and hemlock. Table 5 shows the amount of poplar pulpwood used, by processes, in 1899 and each year from 1905 to 1910, inclusive. The cost of poplar per cord in 1907, 1908, and 1909 is shown in Table 6. The average cost per cord for poplar pulpwood did not change materially during the period 1907 to 1909, though the average cost per cord for all pulpwoods steadily advanced.

\section{PAPER PULP FROM ASPEN.}

\section{CHARACTERISTICS AND PROPERTIES.}

Aspen soda pulp, when unbleached and dry, is a very light brown or light reddishbrown much resembling ordinary blotting paper. While fairly tenacious, the pulps are usually very soft and bulky, whether bleached or unbleached. The softness of the pulp may be partly due to the fact that its natural resin content is normally very low $(0.05$ per cent) as compared with ordinary sulphite pulp (0.5 per cent). Aspen soda pulp is easily bleached to a good white color, though in some cases there may be a slight reddish tinge. For well-cooked pulp very low amounts of bleaching agents are required, and the loss on bleaching (from 6 to 10 per cent in commercial practice) is comparatively small. The following table by Griffin and Little ${ }^{2}$ affords a com-

\footnotetext{
1 For statistics on the consumption of poplar pulpwood by Canadian mills, see bulletins 12, 26, and 30, of the Forestry Branch, Canadian Department of the Interior, 1909-1912.

${ }^{2}$ Chemistry of Papermaking, p. 280, 1894.
} 


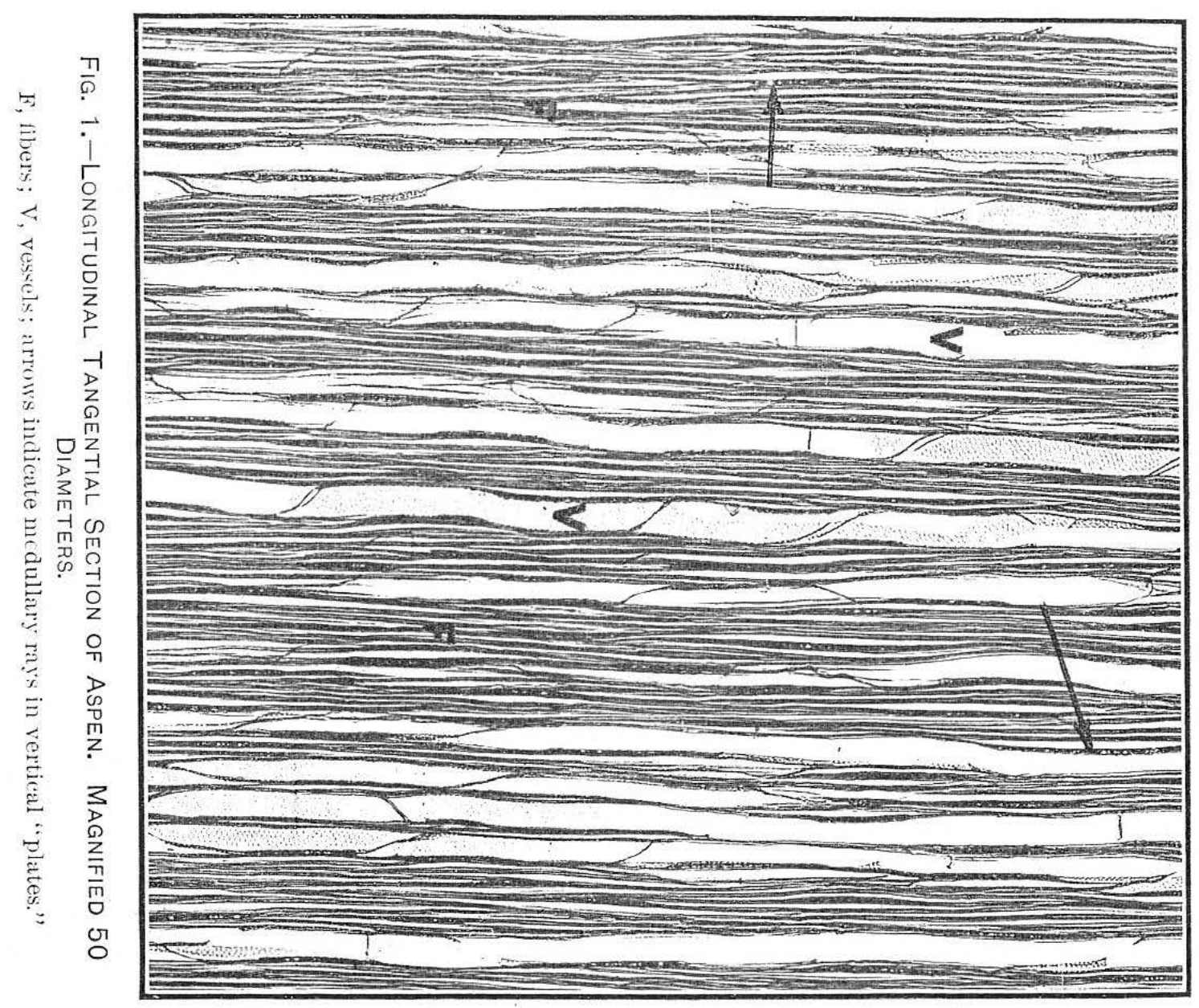

1

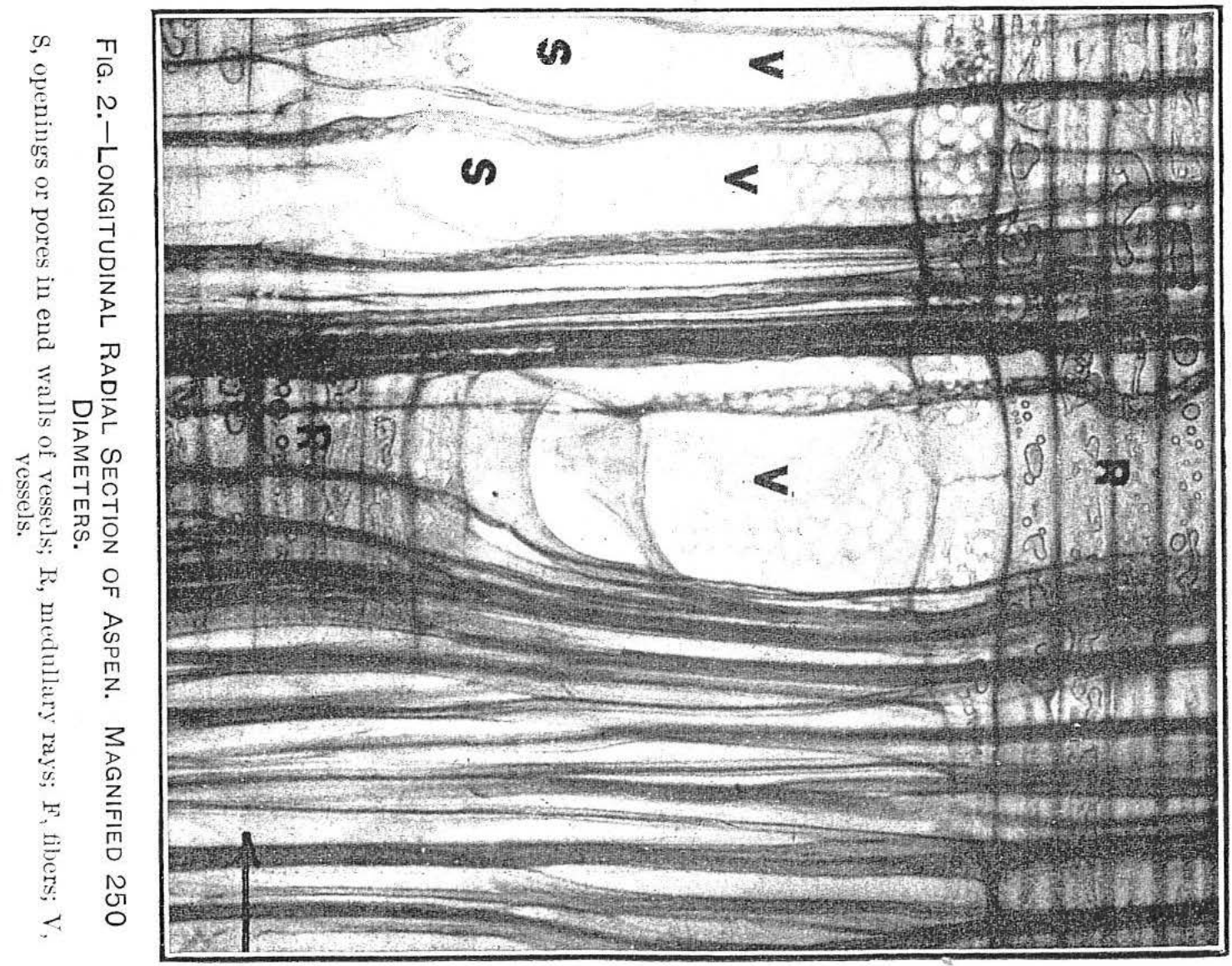



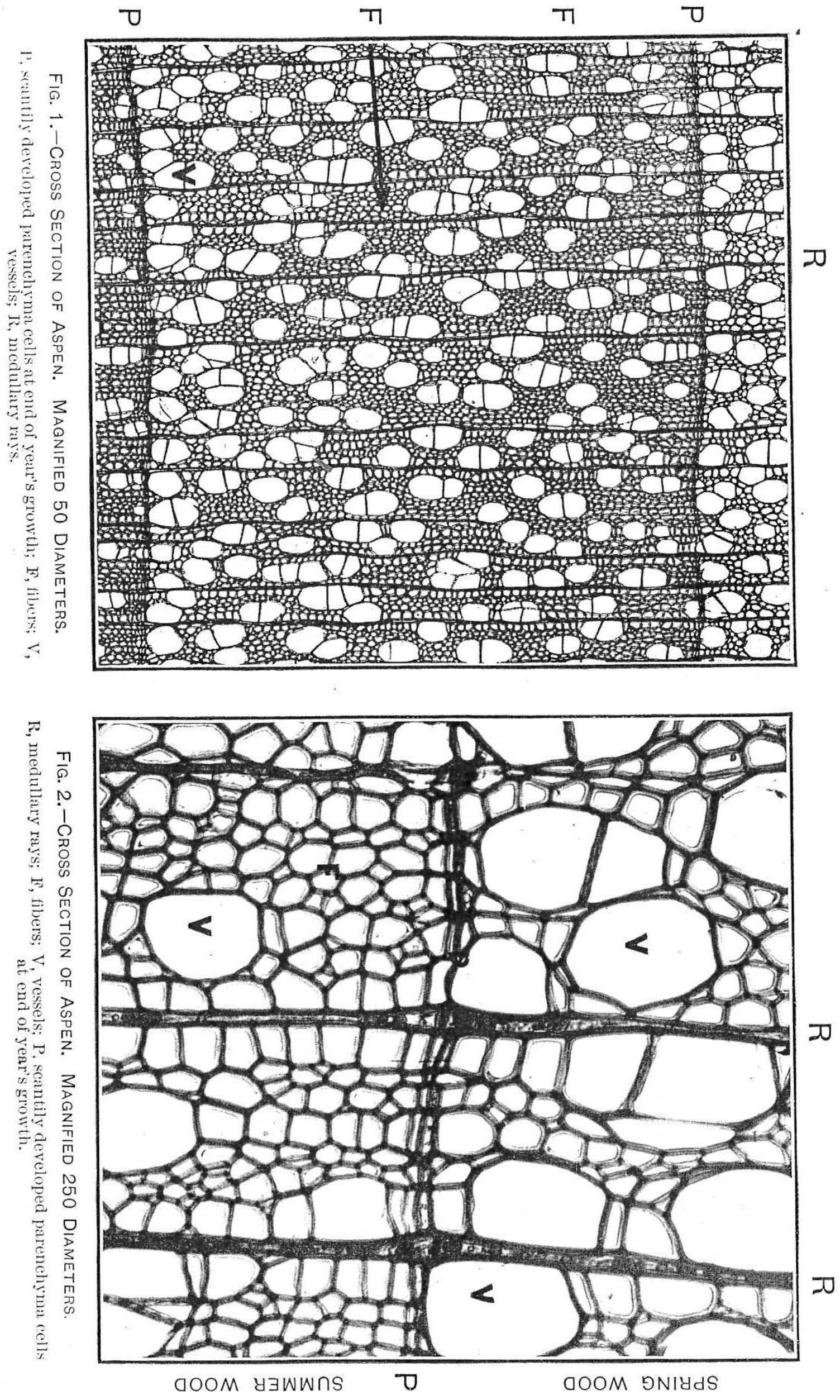
parison between the amounts of bleaching powder required for pulps from poplar (including aspen) and for other pulps:

TABLE 7.-Amount of bleaching powder required for commercial pulps.

\begin{tabular}{|c|c|}
\hline Kind of pulp. & $\begin{array}{c}\text { Bleaching } \\
\text { powder per } \\
100 \text { pounds } \\
\text { of pulp. }\end{array}$ \\
\hline $\begin{array}{l}\text { Soda spruce....... } \\
\text { Soda poplar...... } \\
\text { Soda esparto..... }\end{array}$ & $\begin{array}{r}\text { Pounds. } \\
18-25 \\
12-15 \\
10-15\end{array}$ \\
\hline $\begin{array}{l}\text { Sulphite spruce. } \\
\text { Sulphite poplar.. }\end{array}$ & $\begin{array}{r}15-25 \\
14-20\end{array}$ \\
\hline
\end{tabular}

The individual fibers in aspen soda pulp are of the following dimensions: ${ }^{1}$ Length, from 0.67 to $1.49 \mathrm{~mm}$, averaging $0.99 \mathrm{~mm}$; breadth at the middle, from 0.01 to 0.03 $\mathrm{mm}$., averaging $0.02 \mathrm{~mm}$.; approximate thickness of cell walls, $0.002 \mathrm{~mm}$.; ratio of length to breadth, 50:1. The fibers are slender, gradually tapering to needle-pointed ends. They are pliable and mostly curved, although many are nearly straight. While sometimes twisted and often swollen in nodes, with slight constrictions, they are never badly tangled or knotted. Aspen fibers tend to be more nearly circular in cross section than those from conifers. Other distinguishing characteristics are the medium length of the fibers and the presence, except in "overcooked" pulps, of remnants of the larger wood vessels and parenchymatous tissue. The vessel walls have closely packed bordered pits with hexagonal contour, and the inside walls are not marked with spiral thickenings, as is the case with some species. The vessel ends have open pores without gratings, which distinguishes aspen pulp from that of the tulip tree or yellow poplar sold in European markets under the name "Amerikanische Aspenzellulose." 2

\section{YIELDS,}

The yields reported by a number of American soda-pulp mills operating on aspen and other woods are given in Table 8.

TABLE 8.- Yields of soda pulps reported by various mills. ${ }^{3}$

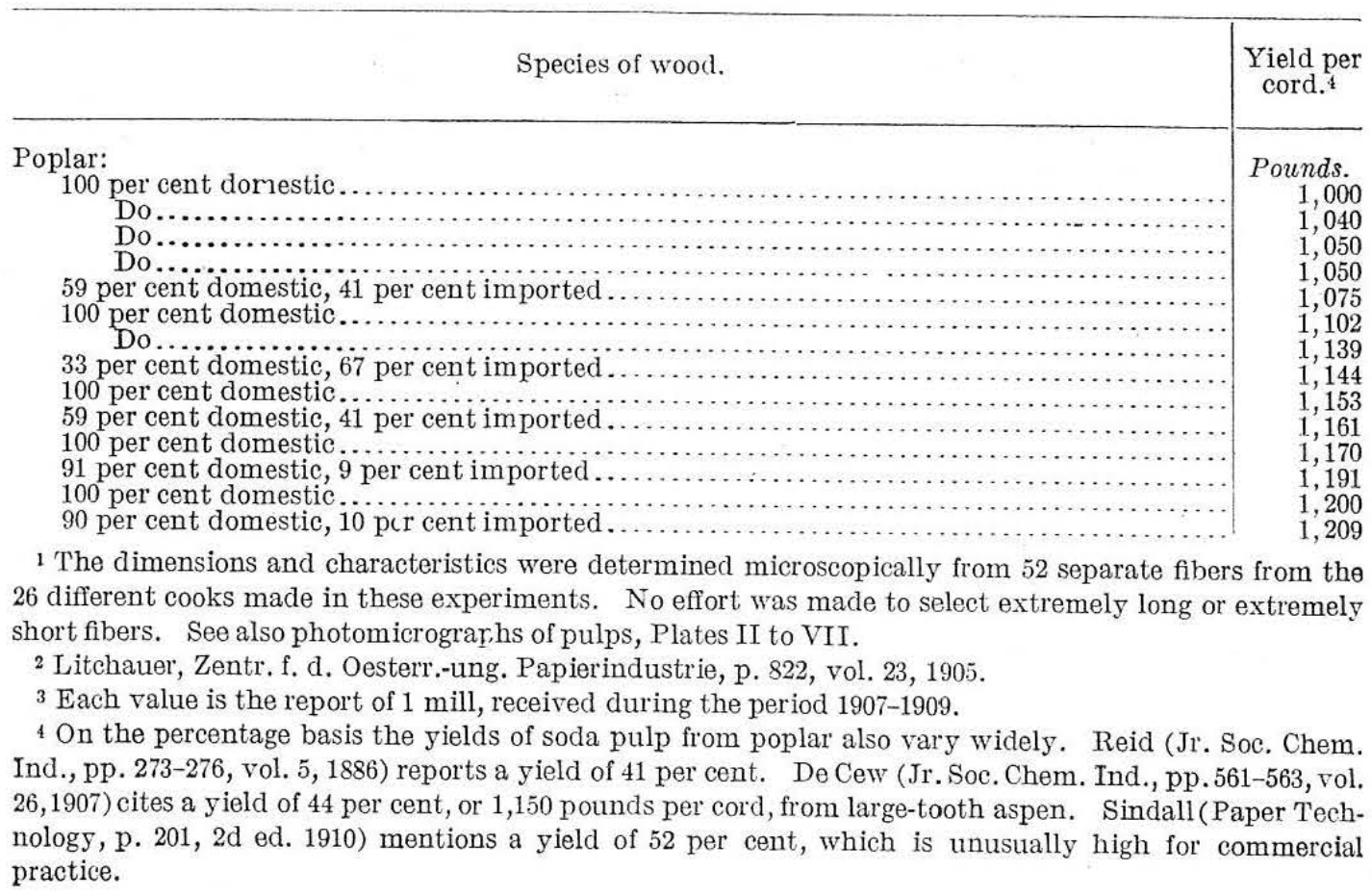


TABLE 8.-Yields of soda pulps reported by various mills-Continued.

\begin{tabular}{|c|c|}
\hline Species of wood. & $\begin{array}{l}\text { Yield per } \\
\text { cord. }\end{array}$ \\
\hline Poplar 11 per cent and pine 89 per cent. . & Pounds. \\
\hline Poplar 91 per cent and chestnut 9 per cent & $\begin{array}{r}1,000 \\
800\end{array}$ \\
\hline Poplar 75 per cent and gum 25 per cent... & 1,000 \\
\hline Poplar 95 per cent and gum 5 per cent.. & 1,139 \\
\hline Poplar 12 per cent, pine 88 per cent, and gum small amount....................... & 985 \\
\hline Poplar 3 per cent, pine 25 per cent, and maple 72 per cent.................................. & 948 \\
\hline 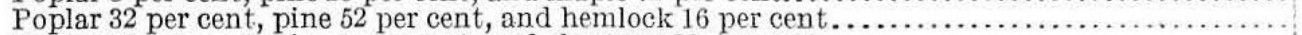 & \\
\hline Poplar 13 per cent, pine 1 per cent, and chestnut 86 per cent $\ldots \ldots \ldots \ldots \ldots \ldots \ldots \ldots \ldots$ & 800 \\
\hline 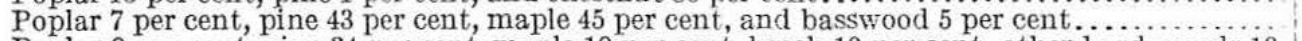 & 1,014 \\
\hline Poplar 9 per cent, pine 34 per cent, maple 19 per cent, beech 19 per cent, other hard woods 19 & \\
\hline 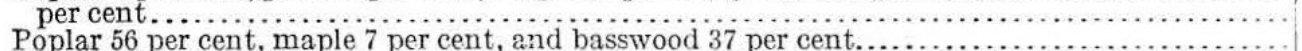 & $\begin{array}{r}794 \\
043\end{array}$ \\
\hline 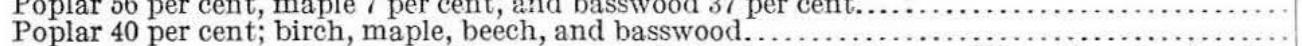 & 1.160 \\
\hline Poplar 30 per cent, cottonwood 30 per cent; maple, buckeye, willow, and lime 10 per cent each.. & 1.000 \\
\hline
\end{tabular}

The several yields were all determined from the amounts of wood consumed annually by each mill and the total production of pulp in the same time. The yields represent air-dry, bleached pulp, except for a few of the mills which used coniferous woods, together with the poplars.

The experimental work of the Forest Service shows that yields of over 55 per cent (bone-dry basis) of unbleached pulp (see Table 11) can be obtained. Even the lowest yield of good unbleached pulp was not less than approximately 45 per cent. A yield of 55 per cent amounts to over 1,450 pounds of bone-dry, unbleached pulp, or over 1,600 pounds of air-dry, bleached pulp, per 100 cubic feet of solid wood. The average 128-foot cord of peeled aspen contains approximately 90 cubic feet of solid wood, ${ }^{1}$ and on this basis would produce 1,440 pounds of air-dry, bleached pulp.

It seems evident, therefore, that considerably higher yields can be obtained from aspen than are secured in commercial practice. One of the many reasons for the lower yields of the commercial plants is probably the quality of the wood. ${ }^{2}$ In the Forest Service tests the wood used was clear and sound, all defective material having been culled.

USES.

The principal use of soda poplar or aspen pulp is in the bleached form for such papers as book, magazine, antique, coated, lithograph, map, card, cover, common envelope, and writing, and wood blotting papers; also the soft, bulky papers some times required for special purposes. In making these papers longer-fibered pulps, that is, bleached rag or sulphite wood pulps, are mixed with the soda pulp in various proportions up to 80 per cent of the whole. These other fibers are added mainly for the purpose of strengthening the soda pulps, and their proportion in the mixture depends upon the desired quality of the product. The use of considerable amounts of soda poplar pulp is favored in some cases because it imparts to the sheet of paper a bulkiness and opacity not readily obtainable with ordinary sulphite or rag pulp alone. The addition of the long-fibered pulps tends to increase the cost of the products, but gives them more lasting qualities. These mixed pulps lend themselves with particular ease to the various paper-making operations, such as sizing, coloring, beating, and running on the paper machine.

The amount of various kinds of wood pulps used in the United States in 1909 and 1899 is shown in Table 9.

1 Forest Service Bulletin 36 (rev. ed., 1910), p. 113, Woodman's Handbook, by H. S. Graves and E. A. Ziegler; alse "Factors Influencing the volume of solid wood in the cord," by R. Zon, Forestry Quarterly, p. 126, No. 4, vol. 1 .

2 In some earlier experiments by the Forest Service considerably lower yields were obtained, which were attributed to the inferior quality of the wood. See Table 15. 
TABLF 9.-Amounts of mechanical, soda, and sulphite wood pulps used in the United States.

\begin{tabular}{|c|c|c|c|c|c|c|}
\hline \multirow{2}{*}{ Kind of pulp. } & \multicolumn{4}{|c|}{ Total pulps. } & \multicolumn{2}{|c|}{ Imported pulps. } \\
\hline & \multicolumn{2}{|c|}{$1909^{1}$} & \multicolumn{2}{|c|}{$1899^{2}$} & \multicolumn{2}{|c|}{$1909^{1}$} \\
\hline 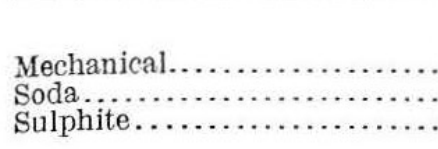 & $\begin{array}{r}\text { Tons. } \\
1,323,000 \\
304,000 \\
1,200,000\end{array}$ & $\begin{array}{r}\text { Per cent. } \\
47 \\
11 \\
42\end{array}$ & $\begin{array}{l}\text { Tons. } \\
586,374 \\
171,959 \\
416,230\end{array}$ & $\begin{array}{r}\text { Per cent. } \\
50 \\
15 \\
35\end{array}$ & $\begin{array}{r}\text { Tons. } \\
119,500 \\
9,500 \\
172,400\end{array}$ & $\begin{array}{l}\text { Cost. } \\
\$ 2,723,000 \\
398,000 \\
8,142,000\end{array}$ \\
\hline Total... & $2,827,000$ & 100 & $1,174,563$ & 100 & 301,400 & $11,263,000$ \\
\hline
\end{tabular}

1 Bureau of the Census-Paper and Wood Pulp Statistics; preliminary report for 1909, issued Apr. 26, 1911 , p. 3

2 Bureau of the Census-Bulletin 99 of the Twelfth Census, pp. 10, 12, 1901.

\section{RECORDS OF THE SERIES TESTS.}

Tables 10 to 14 give the data for the several groups of tests in which the cooking conditions were varied in series.

\section{EXPLANATION OF DATA.}

The following column headings may need explanation:

Water in chips.- The quantity of water or moisture in the chips as charged is expressed in percentage of water based on the calculated bone-dry weight of the chips.

Initial concentrations of digester liquors.-The caustic soda $(\mathrm{NaOH})$ and the sodium carbonate $\left(\mathrm{Na}_{2} \mathrm{CO}_{3}\right)$ concentrations are determined by analysis of the stock soda solution, and are calculated on the basis of total liquid in the charge, including moisture in the chips. The total sodifm oxide $\left(\mathrm{Na}_{2} \mathrm{O}\right)$ is calculated from the proportions of $\mathrm{NaOH}$ and $\mathrm{Na}_{2} \mathrm{CO}_{3}$, each reduced to the sodium-oxide basis. Grams-per-liter concentrations may be converted into the equivalent pounds per gallon by multiplying by 0.00834 . What is sometimes erroneously called percentage concentrations may be obtained by dividing grams-per-liter concentrations by 10 .

Causticity of liquor.-This represents the ratio of sodium oxide in the caustic soda to the total sodium oxide.

Initial volume of digester liquors.-The digester liquors consist of the stock. soda solution and water charged, together with the water in the chips as charged.

Chemicals charged.-The quantities of the several chemicals charged are their dry weights based on the chemical formulæ indicated.

Duration of cooking.-Compare data with figure 3 .

Apparent condensation.- - This is obtained by subtracting the amount of digester liquors at the start of the cook from the amount of liquid in the digester (as read from a water gauge) just before relieving the pressure, and blowing the digester at the end of the cock. It affords a rough measure of the amount of water condensing from the steam used for cooking.

Yields.-The yields of total crude pulp, screenings, and screened pulp are calculated to a bone-dry basis, and are expressed as a percentage of the calculated bonedry weight of the chips. The total crude pulp is the total fibrous material and uncooked chips blown from the digester.

Yields of pulp per solid cord.-In calculating yields to pounds per cord of wood a "solid cord" is considered equivalent to 100 cubic feet of solid wood, green volume, knot free. For the aspen tested, the calculated bone-dry weight per "solid cord" was 2,688 pounds. The yield of bleached pulp, which is given on the air-dry basis ( 10 per cent moisture), is computed by deducting the loss on bleaching and considering 90 pounds of bone-dry pulp equal to 100 pounds of air-dry pulp. 
Color ratings.-These are numerical expressions of the colors of the unbleached pulps, and were determined on machine-made sheets by means of a tint photometer, according to the method described on page 54 .

Average strength.-The strength tests were conducted on machine-made sheets of unbleached pulp in the air-dry condition. ${ }^{1}$ The methods of testing are described on page 54.

Bleach required.-This represents the parts of bleaching powder (35 per cent available chlorine) required to bleach 100 parts bone-dry weight of unbleached pulp to the commercial white color.

Loss on bleaching. - This is based on the calculated bone-dry weight of unbleached pulp lost when bleaching it to the commercial white color, with the stated per cent of bleach.

Causticity of black liquor.-This was determined by analysis, and is the ratio of the sodium oxide in the caustic soda existing as such in the black liquor to the total sodium oxide in the black liquor. The latter represents the total titratable alkali in the ash resulting from calcining the black liquor.

Efficiency in the use of $\mathrm{NaOH}$.- This is the ratio of the amount of caustic soda actually consumed during the cooking operations to the amount of caustic soda originally in the charge. It is calculated from the causticity of the black liquor, assuming that the soda chemicals in the black liquor are all titratable as sodium carbonate, after the liquor has been reduced to an ash.

Wood, soda ash, and bleach employed per ton of pulp.-The volume of wood is based on the average bone-dry weight of aspen used in the tests (2,668 pounds per solid cord). The soda ash represents the total soda ash of 99.1 per cent purity ( 58 per cent $\mathrm{Na}_{2} \mathrm{O}$ ) necessary to furnish the chemicals employed in cooking, assuming that no loss of alkali occurs in causticizing. The bleaching powder represents the dry weight of this chemical, losses in making the bleaching solutions being disregarded.

\footnotetext{
1 The failure of the Schopper tests to show even relatively uniform variations in the strength of pulp as affected by changes in the cooking conditions can not be explained unless that the pulps were not suitable for these tests.
} 


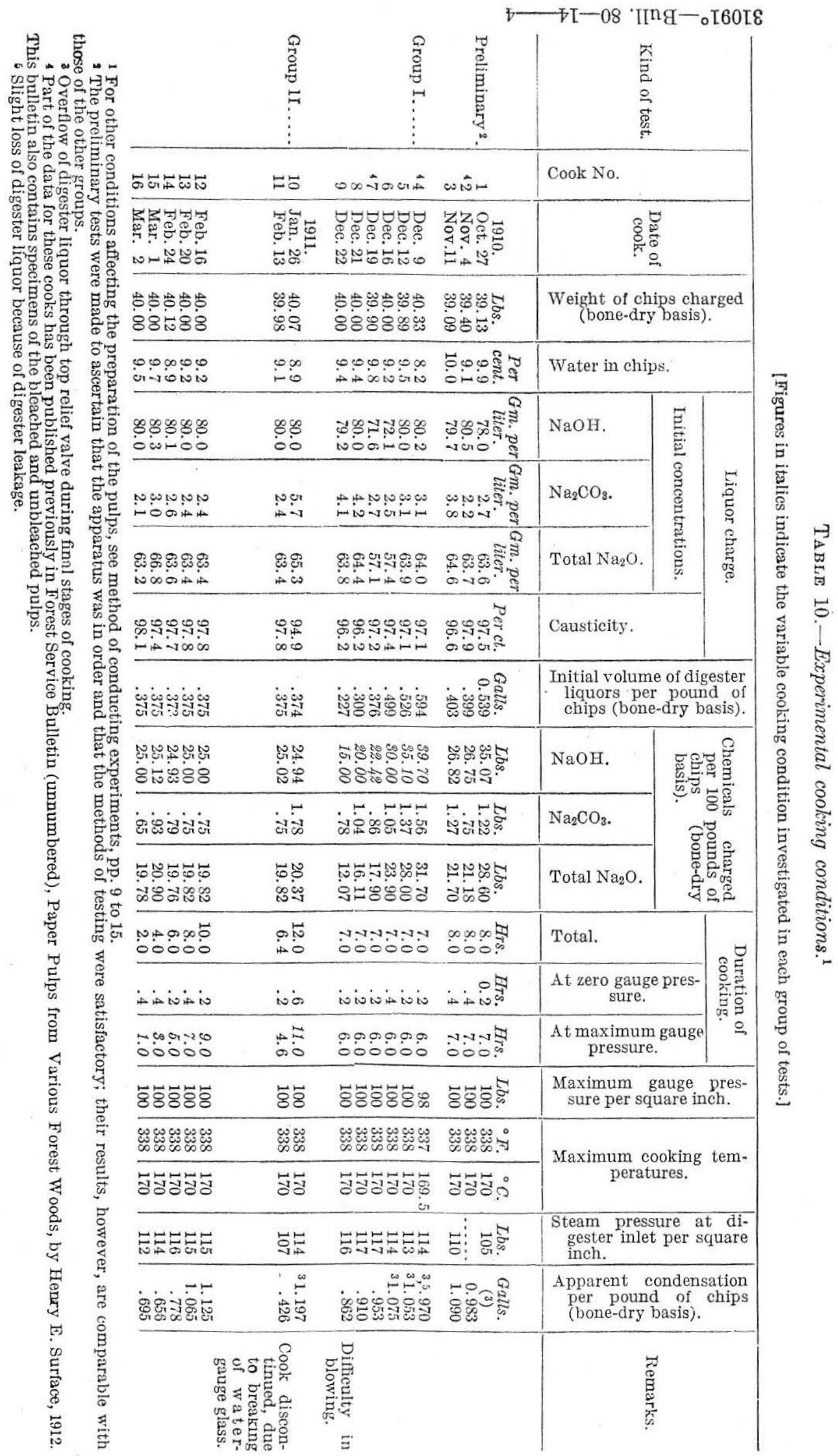




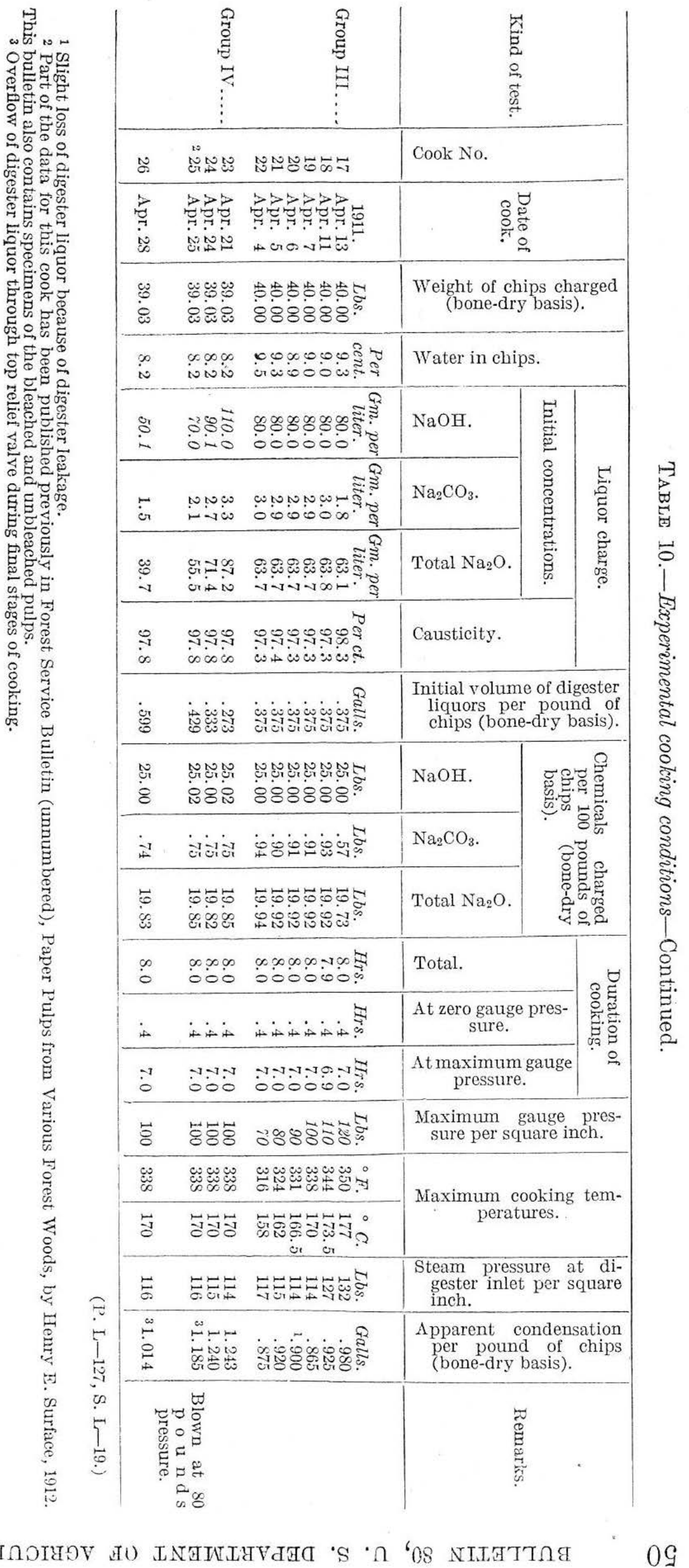


TABLE 11- - Yields of experimental pulps.

\begin{tabular}{|c|c|c|c|c|c|c|}
\hline \multirow[b]{2}{*}{ Kind of test. } & \multirow[b]{2}{*}{$\begin{array}{l}\text { Cook } \\
\text { No. }\end{array}$} & \multicolumn{3}{|c|}{ Yields (bone-dry basis). } & \multirow{2}{*}{$\begin{array}{c}\text { Yields of } \\
\text { un- } \\
\text { bleached } \\
\text { pulp } \\
\text { (bone- } \\
\text { dry basis) } \\
\text { per solid } \\
\text { cord. }\end{array}$} & \multirow{2}{*}{$\begin{array}{l}\text { Yields of } \\
\text { bleached } \\
\text { pulp } \\
\text { (air-dry } \\
\text { basis) } \\
\text { per solid } \\
\text { cord. }\end{array}$} \\
\hline & & $\begin{array}{l}\text { Total } \\
\text { crude } \\
\text { pulp. }\end{array}$ & $\begin{array}{l}\text { Screen- } \\
\text { ings. }\end{array}$ & $\begin{array}{l}\text { Screened } \\
\text { un- } \\
\text { bleached } \\
\text { pulp. }\end{array}$ & & \\
\hline I'reliminary... & $\begin{array}{l}1 \\
2 \\
3\end{array}$ & $\begin{array}{r}\text { Per cent. } \\
48.01 \\
50.34 \\
49.31\end{array}$ & $\begin{array}{r}\text { Per cent. } \\
0.05 \\
.03 \\
.02\end{array}$ & $\begin{array}{r}\text { Per cent. } \\
47.96 \\
50.31 \\
49.29\end{array}$ & $\begin{array}{r}\text { Pounds. } \\
1,279 \\
1,342 \\
1,314\end{array}$ & $\begin{array}{r}\text { Pounds. } \\
1,406 \\
1,475 \\
1,444\end{array}$ \\
\hline 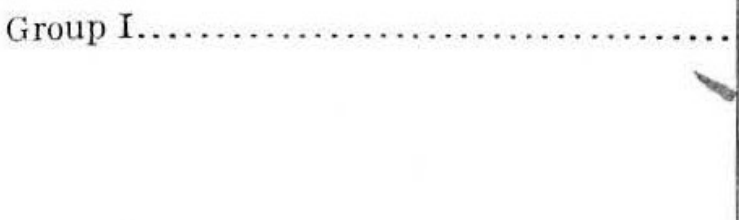 & $\begin{array}{l}4 \\
5 \\
6 \\
7 \\
8 \\
9\end{array}$ & $\begin{array}{l}46.48 \\
50.01 \\
44.67 \\
52.63 \\
55.57 \\
58.30\end{array}$ & $\begin{array}{r}.01 \\
.01 \\
.01 \\
.03 \\
.01 \\
13.02\end{array}$ & $\begin{array}{l}46.47 \\
50.00 \\
44.66 \\
52.60 \\
55.56 \\
45.28\end{array}$ & $\begin{array}{l}1,240 \\
1,334 \\
1,191 \\
1,402 \\
1,482 \\
1,208\end{array}$ & $\begin{array}{l}1,372 \\
1,467 \\
1,308 \\
1,533 \\
1,625 \\
1,315\end{array}$ \\
\hline Group II........ & $\begin{array}{r}10 \\
111\end{array}$ & $\begin{array}{c}50.36 \\
\ldots \ldots\end{array}$ & $\begin{array}{c}.08 \\
\ldots \ldots\end{array}$ & 50.28 & 1,341 & 1,487 \\
\hline . & $\begin{array}{l}12 \\
13 \\
14 \\
15 \\
16\end{array}$ & $\begin{array}{l}51.72 \\
52.49 \\
53.70 \\
55.58 \\
58.12\end{array}$ & $\begin{array}{r}.04 \\
.05 \\
.09 \\
.44 \\
19.00\end{array}$ & $\begin{array}{l}51.68 \\
52.44 \\
53.61 \\
55.14 \\
39.12\end{array}$ & $\begin{array}{l}1,378 \\
1,400 \\
1,429 \\
1,471 \\
1,043\end{array}$ & $\begin{array}{l}1,524 \\
1,524 \\
1,558 \\
1,586 \\
1,109\end{array}$ \\
\hline Group III................ & $\begin{array}{l}17 \\
18 \\
19 \\
20 \\
21 \\
22\end{array}$ & $\begin{array}{l}48.67 \\
50.02 \\
52.55 \\
54.97 \\
54.85 \\
57.88\end{array}$ & $\begin{array}{l}.01 \\
.02 \\
.04 \\
.02 \\
.09 \\
.13\end{array}$ & $\begin{array}{l}48.66 \\
50.00 \\
52.51 \\
54.95 \\
54.76 \\
57.75\end{array}$ & $\begin{array}{l}1,298 \\
1,335 \\
1,400 \\
1,465 \\
1,460 \\
1,541\end{array}$ & $\begin{array}{l}1,422 \\
1,461 \\
1,530 \\
1,612 \\
1,595 \\
1,666\end{array}$ \\
\hline 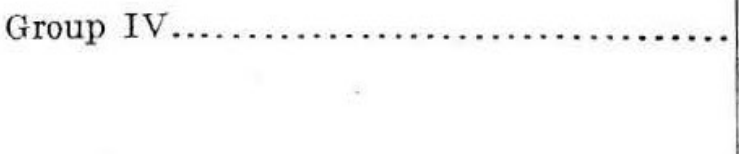 & $\begin{array}{l}23 \\
24 \\
25 \\
26\end{array}$ & $\begin{array}{l}49.18 \\
51.61 \\
50.78 \\
53.58\end{array}$ & $\begin{array}{l}.02 \\
.01 \\
.01 \\
.03\end{array}$ & $\begin{array}{l}49.16 \\
51.60 \\
50.77 \\
53.55\end{array}$ & $\begin{array}{l}1,311 \\
1,376 \\
1,354 \\
1,429\end{array}$ & $\begin{array}{l}1,432 \\
1,521 \\
1,483 \\
1,573\end{array}$ \\
\hline
\end{tabular}

${ }^{1}$ Cook spoiled, due to defect in apparatus. 


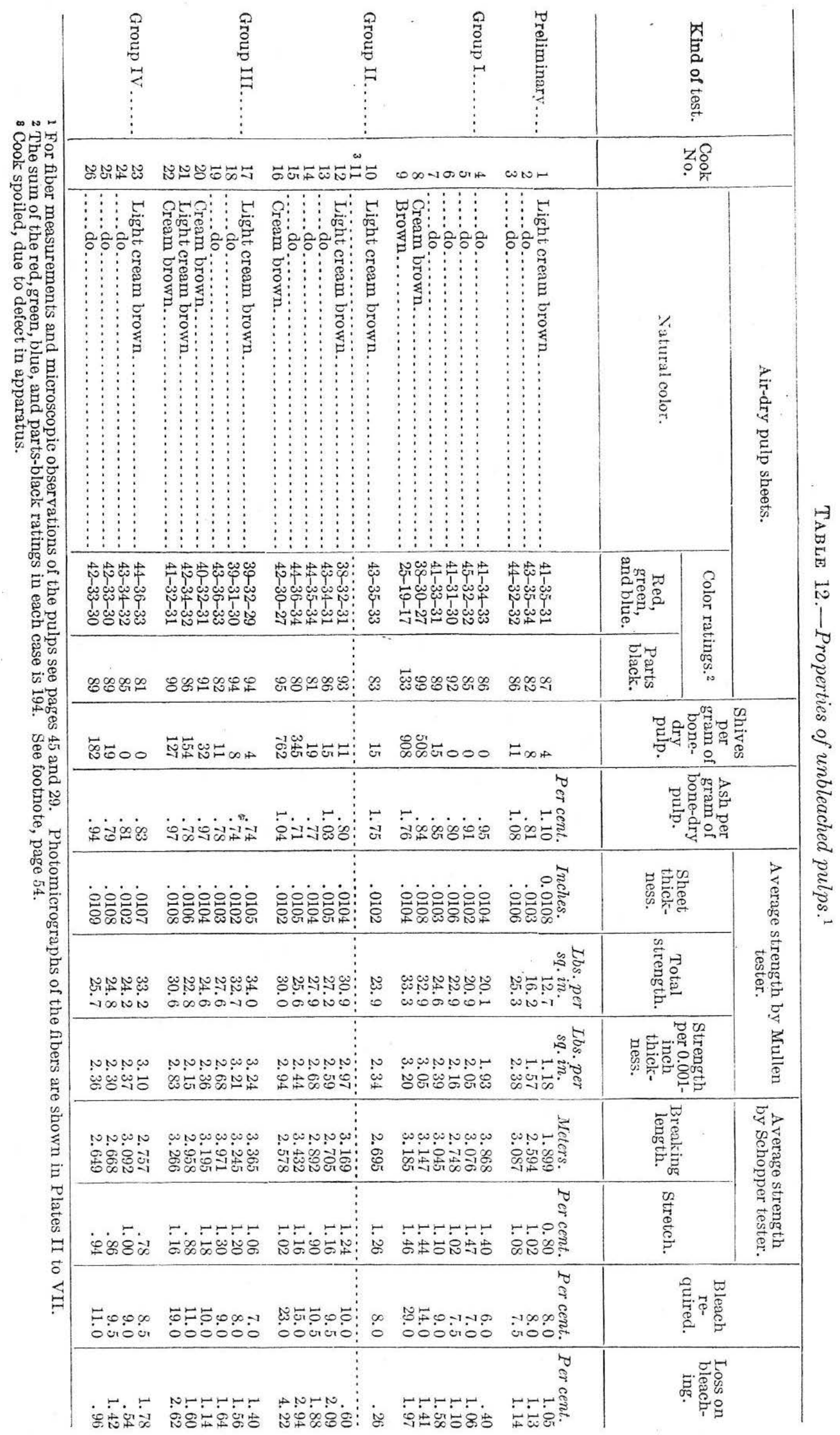


PRODUCING SODA PULP FROM ASPEN.

TABLE 13.-Caustic soda consumed during cooking.

\begin{tabular}{|c|c|c|c|c|c|}
\hline Kind of test. & $\begin{array}{l}\text { Cook } \\
\text { No. }\end{array}$ & $\begin{array}{l}\text { Causticity } \\
\text { of black } \\
\text { liquors. }\end{array}$ & $\begin{array}{l}\text { Efficiency } \\
\text { in the use } \\
\text { of } \mathrm{NaOH} \text {. }\end{array}$ & $\begin{array}{l}\text { NaOH } \\
\text { consumed } \\
\text { per } 100 \\
\text { pounds of } \\
\text { wood } \\
\text { (bone-dry } \\
\text { basis). }\end{array}$ & $\begin{array}{c}\text { NaOH } \\
\text { consumed } \\
\text { per } 100 \\
\text { pounds of } \\
\text { unbleached } \\
\text { pulp (bone- } \\
\text { dry basis). }\end{array}$ \\
\hline Preliminary $\ldots \ldots \ldots \ldots \ldots \ldots \ldots \ldots \ldots \ldots \ldots$ & $\begin{array}{l}1 \\
2 \\
3\end{array}$ & $\begin{array}{r}\text { Per cent. } \\
\text { 13.4 } \\
2.2\end{array}$ & $\begin{array}{r}\text { Per cent. } \\
86.2 \\
97.8\end{array}$ & $\begin{array}{r}\text { Pounds. } \\
23.1 \\
26.2\end{array}$ & $\begin{array}{r}\text { Pounds. } \\
\text { P.r. } \\
45.9 \\
53.2\end{array}$ \\
\hline Group I: $\mathrm{k} \ldots \ldots \ldots \ldots$ & $\begin{array}{l}4 \\
5 \\
6 \\
7 \\
8 \\
9\end{array}$ & $\begin{array}{r}22.3 \\
21.4 \\
14.3 \\
15.3 \\
17.2 \\
2.8\end{array}$ & $\begin{array}{l}77.0 \\
77.9 \\
85.3 \\
84.2 \\
82.1 \\
97.1\end{array}$ & $\begin{array}{l}30.6 \\
27.3 \\
25.6 \\
18.9 \\
16.4 \\
14.6\end{array}$ & $\begin{array}{l}65.9 \\
54.6 \\
57.4 \\
36.0 \\
29.5 \\
32.3\end{array}$ \\
\hline Group II $\ldots \ldots \ldots \ldots \ldots \ldots \ldots \ldots \ldots \ldots \ldots \ldots \ldots \ldots \ldots \ldots \ldots$ & $\begin{array}{r}10 \\
11 \\
12 \\
13 \\
14 \\
15 \\
16\end{array}$ & $\begin{array}{r}4.7 \\
4.6 \\
3.4 \\
10.2 \\
18.0 \\
25.5\end{array}$ & $\begin{array}{r}95.0 \\
\cdots \ldots .4 \\
95.4 \\
96.5 \\
89.6 \\
80.7 \\
74.0\end{array}$ & $\begin{array}{r}23.7 \\
\ldots . .9 \\
23.9 \\
24.1 \\
22.3 \\
20.3 \\
18.5\end{array}$ & $\begin{array}{r}47.1 \\
\cdots \quad 36.2 \\
46.0 \\
41.6 \\
36.8 \\
47.3\end{array}$ \\
\hline Group III $\ldots \ldots \ldots \ldots \ldots \ldots \ldots \ldots \ldots \ldots \ldots \ldots \ldots \ldots$ & $\begin{array}{l}17 \\
18 \\
19 \\
20 \\
21 \\
22\end{array}$ & $\begin{array}{r}5.7 \\
4.7 \\
14.4 \\
20.1 \\
27.1 \\
26.0\end{array}$ & $\begin{array}{l}94.2 \\
95.2 \\
85.2 \\
79.3 \\
72.1 \\
73.2\end{array}$ & $\begin{array}{l}23.6 \\
23.8 \\
21.3 \\
19.8 \\
18.0 \\
18.3\end{array}$ & $\begin{array}{l}48.4 \\
47.6 \\
40.6 \\
36.1 \\
32.9 \\
31.7\end{array}$ \\
\hline 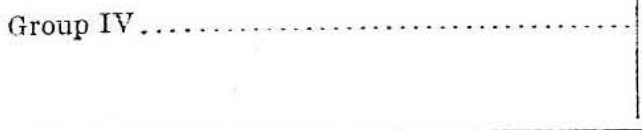 & $\begin{array}{l}23 \\
24 \\
25 \\
26\end{array}$ & $\begin{array}{l}19.4 \\
18.1 \\
17.8 \\
10.3\end{array}$ & $\begin{array}{l}80.2 \\
81.5 \\
81.8 \\
89.5\end{array}$ & $\begin{array}{l}20.1 \\
20.4 \\
20.5 \\
22.4\end{array}$ & $\begin{array}{l}40.9 \\
39.5 \\
40.4 \\
41.9\end{array}$ \\
\hline
\end{tabular}

1 Cook spoiled, due to defect in apparatus.

TABLE 14.-Wood, soda ash, and bleach employed per 2,000-pound ton of air-dry pulp (10 per cent moisture) based on experimental results.

\begin{tabular}{|c|c|c|c|c|c|c|}
\hline \multirow[b]{2}{*}{ Kind of test. } & \multirow[b]{2}{*}{$\begin{array}{l}\text { Cook } \\
\text { No. }\end{array}$} & \multicolumn{2}{|c|}{ Unbleached pulp. } & \multicolumn{3}{|c|}{ Bleached pulp. } \\
\hline & & Wood. & $\begin{array}{c}\text { Soda ash } \\
\text { (58 per } \\
\text { cent } \\
\left.\mathrm{Na}_{2} \mathrm{O}\right)\end{array}$ & Wood. & $\begin{array}{l}\text { Soda ash } \\
\text { (58 per } \\
\text { cent } \\
\left.\mathrm{Na}_{2} \mathrm{O}\right)\end{array}$ & $\begin{array}{c}\text { Bleaching } \\
\text { powder } \\
\text { (35 per } \\
\text { cent } \\
\text { available } \\
\text { chlorine). }\end{array}$ \\
\hline Preliminary ... & $\begin{array}{l}1 \\
2 \\
3\end{array}$ & $\begin{array}{l}\text { Solid } \\
\text { cords. } \\
\quad 1.41 \\
1.34 \\
1.37\end{array}$ & $\begin{array}{r}\text { Pounds. } \\
1,853 \\
1,308 \\
1,367\end{array}$ & $\begin{array}{c}\text { Solid } \\
\text { cords. } \\
1.42 \\
1.36 \\
1.38\end{array}$ & $\begin{array}{r}\text { Pounds. } \\
1,872 \\
1,322 \\
1,384\end{array}$ & $\begin{array}{r}\text { Pounds. } \\
145.5 \\
145.6 \\
136.5\end{array}$ \\
\hline Group I.... & $\begin{array}{l}4 \\
5 \\
6 \\
7 \\
8 \\
9\end{array}$ & $\begin{array}{l}1.45 \\
1.35 \\
1.51 \\
1.28 \\
1.22 \\
1.49\end{array}$ & $\begin{array}{r}2,117 \\
1,738 \\
1,661 \\
1,057 \\
901 \\
828\end{array}$ & $\begin{array}{l}1.46 \\
1.36 \\
1.52 \\
1.30 \\
1.23 \\
1.52\end{array}$ & $\begin{array}{r}2,126 \\
1,757 \\
1,681 \\
1,074 \\
912 \\
844\end{array}$ & $\begin{array}{l}108.4 \\
127.4 \\
136.5 \\
164.6 \\
255.6 \\
532.5\end{array}$ \\
\hline Group II..... & $\begin{array}{r}10 \\
211\end{array}$ & $\begin{array}{c}1.34 \\
\ldots \ldots\end{array}$ & $\begin{array}{c}1,259 \\
\ldots \ldots \ldots\end{array}$ & 1.34 & 1,259 & 144.3 \\
\hline & $\begin{array}{l}12 \\
13 \\
14 \\
15 \\
16\end{array}$ & $\begin{array}{l}1.31 \\
1.28 \\
1.26 \\
1.22 \\
1.72\end{array}$ & $\begin{array}{l}1,191 \\
1,172 \\
1,145 \\
1,177 \\
1,571\end{array}$ & $\begin{array}{l}1.31 \\
1.31 \\
1.28 \\
1.26 \\
1.80\end{array}$ & $\begin{array}{l}1,196 \\
1,196 \\
1,167 \\
1,211 \\
1,642\end{array}$ & $\begin{array}{l}181.2 \\
174.7 \\
192.7 \\
278.1 \\
432.3\end{array}$ \\
\hline Group III...... & $\begin{array}{l}17 \\
18 \\
19 \\
20 \\
21 \\
22\end{array}$ & $\begin{array}{l}1.38 \\
1.35 \\
1.28 \\
1.22 \\
1.23 \\
1.17\end{array}$ & $\begin{array}{l}1,258 \\
1,235 \\
1,178 \\
1,126 \\
1,128 \\
1,071\end{array}$ & $\begin{array}{l}1.41 \\
1.37 \\
1.31 \\
1.24 \\
1.25 \\
1.20\end{array}$ & $\begin{array}{l}1,276 \\
1,254 \\
1,196 \\
1,137 \\
1,148 \\
1,101\end{array}$ & $\begin{array}{l}127.8 \\
146.2 \\
164.7 \\
182.1 \\
201.2 \\
351.2\end{array}$ \\
\hline Group IV ....... & $\begin{array}{l}23 \\
24 \\
25 \\
26\end{array}$ & $\begin{array}{l}1.38 \\
1.31 \\
1.33 \\
1.26\end{array}$ & $\begin{array}{l}1,254 \\
1,191 \\
1,214 \\
1,149\end{array}$ & $\begin{array}{l}1.39 \\
1.32 \\
1.35 \\
1.28\end{array}$ & $\begin{array}{l}1,276 \\
1,199 \\
1,232 \\
1,160\end{array}$ & $\begin{array}{l}155.7 \\
162.9 \\
173.5 \\
200.0\end{array}$ \\
\hline
\end{tabular}

1 Cook spoiled, due to defect in apparatus. 


\section{METHODS FOR AUXILIARY TESTS.}

In determining bone-dry weights, properties of pulps, and concentrations of soda liquors, the following methods were employed:

\section{BONE-DRY WEIGHTS.}

In practically all determinations involving exact quantities of wood, pulp, or screenings, either actual or calculated bone-dry weights were used. The actual bone-dry weight is the weight of the material after having been dried to constant weight in an oven with good circulation of pure air at a temperature of $104-106^{\circ} \mathrm{C} .{ }^{1}$ Usually instead of drying the entire quantity of material, its "bone-dry factor," or the ratio of the bone-dry weight to the weight before drying, was determined by means of a small sample. The calculated bone-dry weight is the weight obtained by use of this factor. The errors in calculated bone-dry weights were found by actual test to be less than 0.3 per cent.

\section{PROPERTIES OF UNBLEACHED PULP.}

Color.-The color of a pulp was determined by visual observation and also by means of an Ives new construction tint photometer. The standard for comparison was a block of magnesium carbonate, which affords photometer readings of 100 each for the red, green, and blue color screens used. The sum of the three readings for a pulp measures its "whiteness," and this sum subtracted from $300^{2}$ (the sum of the three readings for a surface as white as the standard) measures the "parts black" rating of the pulp. The higher the "parts black" value the darker is the pulp. This method of expressing relative "darkness" of different pulps is reliable only when the pulps are of approximately the same hue, as in the case of these experiments.

Shives.-Shives in pulp are the small bundles of wood fibers which were not reduced by the cooking and subsequent operations, and which were not removed by the pulp screens. For the determination, a three-tenths-gram portion of pulp, the bone-dry factor of which was known, was thoroughly broken up in a small Erlenmeyer flask and deposited on a 70-mesh sieve in an even deposit or sheet covering 9.66 square inches. This sheet was "couched" on a silk cloth and then transferred to a glass plate and dried in an oven. When the plate with the deposit was placed in front of an incandescent lamp the shives could easily be counted with the eye. In cases where the number was large, a glass plate divided into quarter-inch squares was placed on top of the pulp and a small area was examined instead of the whole. Knowing the area examined and the bone-dry weight of the pulp sheet, the number of shives per gram of bone-dry pulp could be calculated.

Ash.-The ash was determined by burning a bone-dry sample of unbleached pulp of known weight in a platinum or porcelain dish over a Bunsen flame until the ash produced was free from carbon and of a white or grayish-white color. The percentage of ash is based on the bone-dry weight of the pulp.

Strength.-The strength of the pulp sheets made on the paper machine was determined by a Mullen paper tester and by a Schopper breaking-length testing instrument. The pulp was tested in the ordinary air-dry state for the conditions that prevailed in the laboratory. The Mullen test, or "pop test" as it is sometimes called, was made by clamping a single sheet, accurately measured for thickness, between a rubber diaphragm and a polished metal ring, and then, by means of liquid under pressure, forcing the diaphragm against the pulp sheet until it burst through the aperture. The pressure on the liquid in pounds per square inch, or "points," is read from a

1 The weight was considered constant when the decrease was not more than 0.1 per cent during an additional hour's drying at this temperature.

2 At the time of these experiments the shutter of the instrument used had been injured and could not be opened more than 64.7 points. The other aperture was then reduced to this size and the value 64.7 was used in place of 100 for a wide-open aperture, and 194 ( 3 times 64.7) was used in place of 300 . The results obtained for the various pulps were sufflciently accurate for comparison with each other. 
gauge. For each pulp 20 sheets whose thickness varied between 0.010 and 0.011 inch were tested. The average strength in pounds per square inch per 0.001 inch thickness is the quotient of the average test value divided by the average thickness in thousandths of an inch. A quantity one-tenth of this value is sometimes used in expressing results, and is called the "strength ratio." 1 The Schopper tester measures in kilograms weight the tensile stress required to break a strip of pulp $15 \mathrm{~mm}$. wide. At the same time the instrument registers the "per cent stretch," which is the strain or elongation of the strip just before breaking, and is expressed as a percentage of the original length. The "breaking length" is the length of sheet which, if suspended, would break of its own weight, and when expressed in meters is determined by multiplying the weight in kilograms required to break the strip by its testing length in millimeters $(180 \mathrm{~mm}$.$) , and dividing the product by the weight in grams of the portion$ of the strip subjected to test. Five strips of pulp were tested in the "machine direction" of the sheet and five across the machine direction, and the average values for the two directions determined.

Bleach required.-The bleaching solution was made by mixing bleaching powder (calcium oxy-chloride or chloride of lime) with water and allowing the mixture to settle so that a clear solution was obtained. The strength of this solution was determined by titrating $5.00 \mathrm{cc}$. against fifth normal arsenious acid solution, using a solution of starch paste and potassium iodide as indicator. The number of cubic centimeters of arsenious acid used, multiplied by 4.0514 , gave the strength of the bleaching solution in grams per liter of " 35 per cent bleach," or bleaching powder, in which 35 per cent of its weight is chlorine available for bleaching purposes. The bone-dry weight (about 50 grams) of the pulp sample used for the bleaching determination was first calculated by means of its bone-dry factor. The sample was then thoroughly broken up in water ${ }^{2}$ to form a uniform pulp mixture. A quantity of the bleaching solution containing a known weight of " 35 per cent bleach" was added and the mixture diluted with water ${ }^{2}$ to approximately $2,500 \mathrm{cc}$. This mixture was kept at a temperature of $40^{\circ} \mathrm{C}$. until the bleach was exhausted, as determined by starch-iodide indicator. The bleached fiber was then thoroughly washed free from bleach residues and made up into sheets on a small hand mold. These sheets, when air-dry, were compared with air-dry standard color sheets made in a similar manner from five or six commercially bleached soda pulps mixed in equal proportions. If the first determination on the experimental pulp did not give as white a color as the standard, the process was repeated on other samples until the standard color was attained as nearly as possible. ${ }^{3}$ The weight of 35 per cent bleach required to produce the standard color is expressed as a percentage of the bone-dry weight of the pulp. The bleaching operations were performed in enameled jars provided with agitators and placed in a tank of water whose temperature could be regulated by an electric heater. It was found best to start the bleaching in the late afternoon or evening, so that the bleach was exhausted sometime the next morning. The comparisons with the standard color sheets should be made at about the same time each day, using light from a north window.

Loss on bleaching.-For determining the loss on bleaching, a sample of about 2 grams of pulp was thoroughly broken up in water and bleached in a $250 \mathrm{cc}$. Erlenmeyer flask, using as near as possible the conditions which produced the standard

1 "Strength factor" or "points per pound" is distinguished from "strength ratio" by the former being obtained by dividing the "pop test" by the weight in pounds of a ream of paper. The size of a ream varies, but for a standard of comparison a ream of 500 sheets, 24 by 36 inches, is usually preferred for determining the strength factor.

2 The water should be neutral so far as its action on pulp and on bleaching powder solution is concerned. The use of distilled water is preferable.

3 Actual tests have shown that this method gives results almost identical to those secured in pulp-mill operations. The method of determining the amount of bleach required by adding an excess of bleaching powder and titrating the unconsumed excess after the pulp is bleached sufficiently white, gives much lower results. 
color in the samples tested for the determination of the amount of bleach required. The bleached sample was thoroughly washed, first with hot distilled water and afterwards with ethyl alcohol. Its bone-dry weight was then determined. The percentage loss on bleaching is based on the bone-dry weight of the unbleached pulp, which had been calculated from its bone-dry factor.

Microscopic examinations.-Pepresentative portions from the pulp sheets were soaked in water, teased apart with a needle, stained with Bismarck brown, dehydrated with absolute ethyl alcohol, cleared in xylol, and made into permanent mounts with Canada balsam. Photomicrographs of these mounts magnified 65 diameters were used in studying the individual fiber characteristics. Further microscopic study of each of the individual mounts was also made, using different magnifications, and such features were observed as the apparent strength of cell walls, the prominence of cell markings and the presence of vessels, fiber bundles (shives), and ray cells. The general shape and condition of the fibers and the distinguishing characteristics for the species were noted. By means of a micrometer eyepiece about 50 unbroken fibers from the various mounts were measured for length and breadth at the middle of the fibers, and the average thickness of the cell walls was roughly estimated. The fibers were selected at random, no effort being made to select extremely long or short ones.

\section{ANALYSES OF SODA LIQUORS.}

The caustic-soda solutions charged and the black liquors from the leached pulps were examined for their contents of cooking chemicals, in the first case to calculate sizes of charges, and in the second to determine the consumption of caustic soda during cooking.

Caustic soda liquor.-The examination of the caustic soda liquor was conducted as follows: A 10 cc. portion was titrated against normal sulphuric acid, using phenolphthalein as first indicator and methyl orange indicator to finish the titration. Letting $\mathrm{Y}=$ the number of cubic centimeters of normal acid solution required for the first end point and $\mathrm{X}=$ the number of cubic centimeters required for the final end point, the following equations were used for calculating the concentration of caustic soda $(\mathrm{NaOH})$ and the causticity:

$$
\begin{aligned}
& 4(\mathrm{Y}-(\mathrm{X}-\mathrm{Y}))=\text { grams per liter of } \mathrm{NaOH} . \\
& \frac{100(\mathrm{Y}-(\mathrm{X}-\mathrm{Y}))}{\mathrm{X}}=\text { per cent causticity. }
\end{aligned}
$$

Black liquor.-The examination of black liquor was conducted as follows:

(1) A 50 cc. portion of black liquor was evaporated to dryness in a platinum dish. The residue was ashed over a Bunsen burner and the soluble salts were leached out with hot distilled water. The entire solution obtained was titrated with normal sulphuric acid, using methyl orange as indicator. The number of cubic centimeters of acid required to produce the end point multiplied by 0.62 gives the grams per liter of total sodium oxide $\left(\mathrm{Na}_{2} \mathrm{O}\right)$ in the black liquor.

(2) A $100 \mathrm{cc}$. portion of the same black liquor was mixed with $50 \mathrm{cc}$. of 10 per cent barium chloride solution in a $500 \mathrm{cc}$. calibrated flask. The mixture was then diluted to $500 \mathrm{cc}$. with neutralized or freshly distilled water free from carbon dioxide and thoroughly agitated. After settling, $50 \mathrm{cc}$. of the clear supernatant liquor were titrated with tenth normal hydrochloric acid, using phenolphthalein as indicator. The number of cubic centimeters of acid required for the end point multiplied by 0.401 gives the number of grams per liter of free caustic soda $(\mathrm{NaOH})$ in the black liquor.

(3) The causticity of the black liquor was calculated from the following equation:

In which:

$$
\frac{\mathrm{A}(0.775) 100}{\mathrm{~B}}=\text { per cent causticity. }
$$

$A=$ the number of grams per liter concentration of caustic soda $(\mathrm{NaOH})$.

$\mathrm{B}=$ the number of grams per liter concentration of total sodium oxide $\left(\mathrm{Na}_{2} \mathrm{O}\right)$. 


\section{\&UTOCLAVE TESTS ON ASPEN.}

A few autoclave tests on aspen (Populus tremuloides Michx.) were made in 1909. ${ }^{1}$ The ordinary soda process was employed, but the digester used was a horizontal, rotary autoclave, made of 6 -inch steel pipe, with a capacity of about 2 gallons. As the heat was furnished by Bunsen burners, there was no condensation or loss of liquid through overflow to modify the cooking conditions. Cooks were not blown, but the digester was quickly cooled to room temperature and then dumped. The pulps were thoroughly washed with cold water and screened on a small diaphragm screen through slots of 0.006 inch width. The test material was cut from fairly young growth near Ridgeway, Colo. Portions of the logs tested, especially the centers and around knots, were discolored a dull reddish-brown, probably due to incipient fungous attack; otherwise the wood seemed to be sound. Chips were prepared in the manner described on page 15. Their sizes were five-eighths inch (with the grain) by three-sixteenths to one-fourth inch by one-half inch to 6 inches (both across the grain).

The data resulting from the tests are shown in Table 15. The column headings have the same significance as those in Tables 10 to 14, except as otherwise indicated. However, in the bleaching tests the standard color matched was that of bleached sulphite pulp, and, as soda poplar pulp in commercial operations is never bleached to so white a color, the test data should be reduced somewhat in estimating the commercial value for bleach required. The values for loss on bleaching also are probably a little greater on this account.

The tests fall naturally into two groups. One of these consists of cooks 1,2 , and 4 , in which the concentration of caustic soda in the cooking liquors was varied. The other consists of cooks 3 and 5 , in which the duration at maximum pressure was the chief variable. Increases either of concentration or of duration resulted in decreases in the yield of pulp, loss on bleaching, and bleach required, except possibly in the case of one cook. All of the pulps produced were thoroughly cooked. The yields, as compared with those secured in the more recent tests (see Table 11), were uniformly very low and the losses on bleaching very high. The difference may be due to the methods and apparatus used or to deterioration of the wood from fungous attack, or to both. If the wood had been perfectly sound, it does not seem probable that the lower yields would have been accompanied by the higher amounts of bleach required and the larger losses on bleaching, even though these effects were slightly augmented by the higher standard of bleaching.

TABLE 15.-Cooking conditions and results of autoclave tests on aspen.

\begin{tabular}{|c|c|c|c|c|c|c|c|c|c|c|c|}
\hline \multirow{3}{*}{$\begin{array}{l}\text { Cook } \\
\text { No. }\end{array}$} & \multirow{3}{*}{$\begin{array}{c}\text { Date of } \\
\text { cook. }\end{array}$} & \multirow{3}{*}{$\begin{array}{l}\text { Weight } \\
\text { of chips } \\
\text { charged } \\
\text { (bone-dry } \\
\text { basis). }\end{array}$} & \multirow{3}{*}{$\begin{array}{c}\text { Waier } \\
\text { in } \\
\text { chips. }\end{array}$} & \multicolumn{4}{|c|}{ Liquor charge. } & \multirow{3}{*}{$\begin{array}{c}\text { Initial } \\
\text { volume of } \\
\text { digester } \\
\text { liquors }{ }^{2} \\
\text { per } \\
\text { pound of } \\
\text { chips } \\
\text { (bone-dry } \\
\text { basis). }\end{array}$} & \multirow{2}{*}{\multicolumn{3}{|c|}{$\begin{array}{l}\text { Chemicals charged per } \\
100 \text { pounds of chips } \\
\text { (bone-dry basis). }\end{array}$}} \\
\hline & & & & \multicolumn{3}{|c|}{ Initial concentrations. ${ }^{2}$} & \multirow{2}{*}{$\begin{array}{l}\text { Caus- } \\
\text { ticity. }\end{array}$} & & & & \\
\hline & & & & $\mathrm{NaOH}$ & $\mathrm{Na}_{2} \mathrm{CO}_{3}$. & $\begin{array}{l}\text { Total } \\
\mathrm{Na}_{2} \mathrm{O}\end{array}$ & & & $\mathrm{NaOH}$. & $\mathrm{Na}_{2} \mathrm{CO}_{3}$ & $\begin{array}{l}\text { Total } \\
\mathrm{Na}_{2} \mathrm{O} \text {. }\end{array}$ \\
\hline $\begin{array}{l}1 \\
2 \\
3 \\
4 \\
5\end{array}$ & \begin{tabular}{|c|} 
1909. \\
May 25 \\
May 27 \\
June 2 \\
June 8 \\
July 3
\end{tabular} & $\begin{array}{l}\text { Lbs. } \\
1.652 \\
1.652 \\
1.652 \\
1.304 \\
1.920\end{array}$ & $\begin{array}{r}P . c t . \\
33.5 \\
33.5 \\
33.5 \\
18.3 \\
15.0\end{array}$ & $\begin{array}{r}\text { Grams } \\
\text { per liter. } \\
80 \\
50 \\
90 \\
30 \\
90\end{array}$ & \begin{tabular}{|r|} 
Grams \\
perliter. \\
7.4 \\
1.8 \\
4.3 \\
1.4 \\
4.3
\end{tabular} & $\begin{array}{c}\text { Grams } \\
\text { perliter. } \\
66.3 \\
39.8 \\
72.3 \\
24.1 \\
72.3\end{array}$ & $\begin{array}{r}P . c t . \\
93.5 \\
97.5 \\
96.5 \\
96.5 \\
96.5\end{array}$ & $\begin{array}{r}\text { Galls. } \\
0.375 \\
.599 \\
.386 \\
1.000 \\
.390\end{array}$ & $\begin{array}{l}\text { Lbs. } \\
25.0 \\
25.0 \\
29.0 \\
25.0 \\
29.3\end{array}$ & $\begin{array}{r}\text { Lbs. } \\
2.3 \\
.9 \\
1.4 \\
1.2 \\
1.4\end{array}$ & $\begin{array}{r}\text { Lbs. } \\
20.7 \\
19.9 \\
23.3 \\
20.1 \\
23.5\end{array}$ \\
\hline
\end{tabular}

1 These tests were made by Mr. Edwin Sutermeister, formerly in charge of the pulp-testing laboratory of the Forest Service at Washington, D. C.

2 The water in the chips when charged is not taken into consideration. 
TABLE 15.-Cooking conditions and results of autoclave tests on aspen-Continued.

\begin{tabular}{|c|c|c|c|c|c|c|c|c|c|c|}
\hline \multirow{2}{*}{$\begin{array}{l}\text { Cook } \\
\text { No. }\end{array}$} & \multicolumn{3}{|c|}{ Duration of cooking. } & \multirow{2}{*}{$\begin{array}{l}\text { Maxi- } \\
\text { mum } \\
\text { gauge } \\
\text { pressure } \\
\text { per } \\
\text { square } \\
\text { inch. }\end{array}$} & \multicolumn{3}{|c|}{ Yields (bone-dry basis). } & \multicolumn{3}{|c|}{$\begin{array}{l}\text { Properties of unbleached } \\
\text { pulps. }{ }^{1}\end{array}$} \\
\hline & Total. & $\begin{array}{l}\text { At zero } \\
\text { gauge } \\
\text { pres- } \\
\text { sure. }\end{array}$ & $\begin{array}{c}\text { maxi- } \\
\text { mum } \\
\text { gauge } \\
\text { pres- } \\
\text { sure. }\end{array}$ & & $\begin{array}{l}\text { Total } \\
\text { crude } \\
\text { pulp. }\end{array}$ & $\begin{array}{l}\text { Screen- } \\
\text { ings. }\end{array}$ & $\begin{array}{l}\text { Screened } \\
\text { pulp. }\end{array}$ & Ash. & $\begin{array}{c}\text { Bleach } \\
\text { required. }\end{array}$ & $\begin{array}{l}\text { Loss on } \\
\text { bleach- } \\
\text { ing. }\end{array}$ \\
\hline $\begin{array}{l}1 \\
2 \\
3 \\
4 \\
5\end{array}$ & $\begin{array}{r}\text { Hrs. } \\
8.2 \\
8.5 \\
4.5 \\
8.0 \\
8.0\end{array}$ & $\begin{array}{r}\text { Hrs. } \\
0.3 \\
.3 \\
.3 \\
.2 \\
.3\end{array}$ & $\begin{array}{r}\text { Hrs. } \\
7.0 \\
7.0 \\
3.0 \\
7.0 \\
7.0\end{array}$ & $\begin{array}{r}L b \text { s. } \\
110 \\
110 \\
110 \\
110 \\
110\end{array}$ & $\begin{array}{l}\text { P. ct. } \\
41.10 \\
44.23 \\
40.50 \\
46.97 \\
36.00\end{array}$ & $\begin{array}{r}\text { P.ct. } \\
0.10 \\
.03 \\
.10 \\
.07 \\
.00\end{array}$ & $\begin{array}{l}\text { P. ct. } \\
41.00 \\
44.20 \\
40.40 \\
46.90 \\
36.00\end{array}$ & $\begin{array}{r}P . c t . \\
1.40 \\
1.27 \\
1.35 \\
1.25 \\
1.42\end{array}$ & $\begin{array}{r}P . c t . \\
15.4 \\
14.7 \\
14.3 \\
15.8 \\
10.0\end{array}$ & $\begin{array}{l}\text { P. ct. } \\
3.92 \\
4.08 \\
4.39 \\
4.68 \\
2.56\end{array}$ \\
\hline
\end{tabular}

(P. L. -66-1, S. 683.)

1 The pulps produced were of good strength and of a fair degree of hardness; the color was very light reddish-brown. Shives were very few in number or almost absent. 


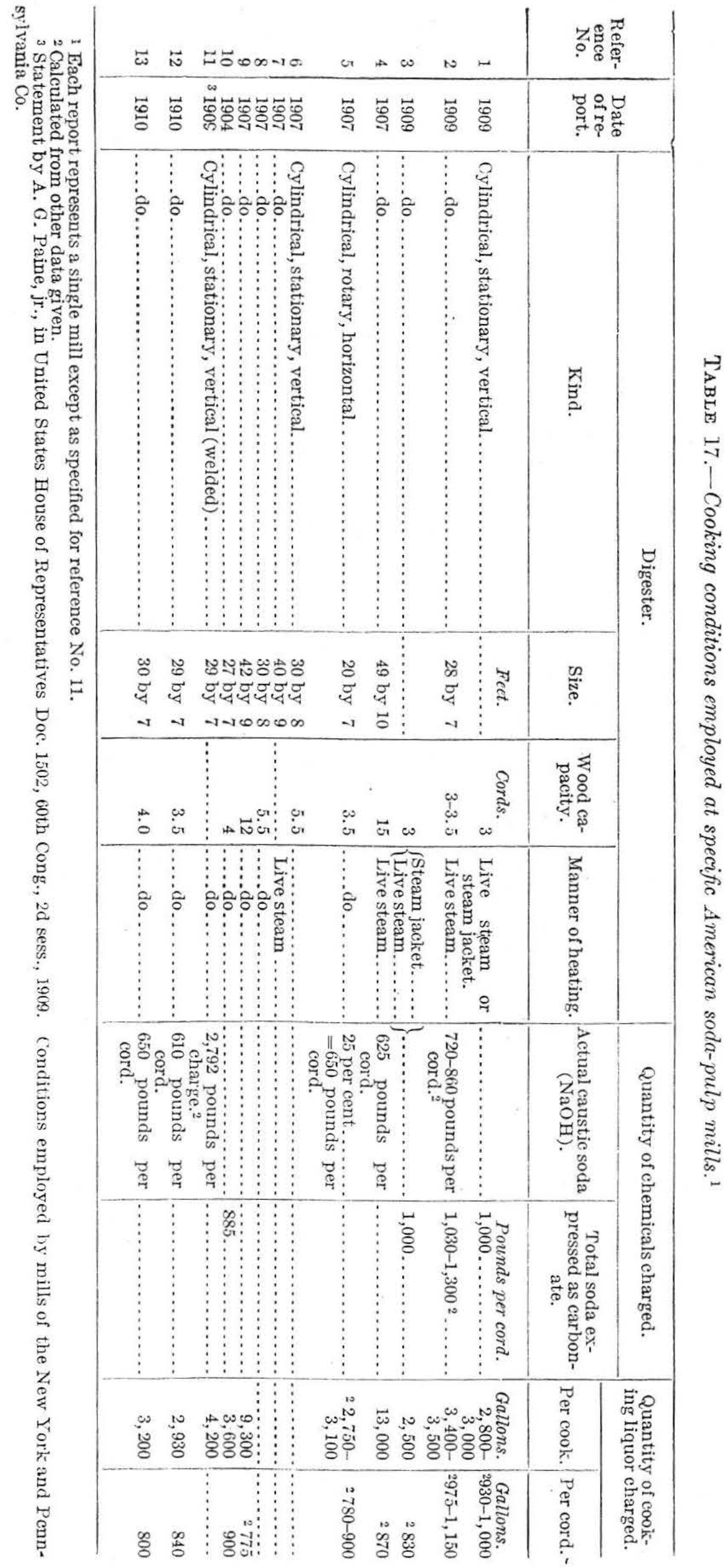




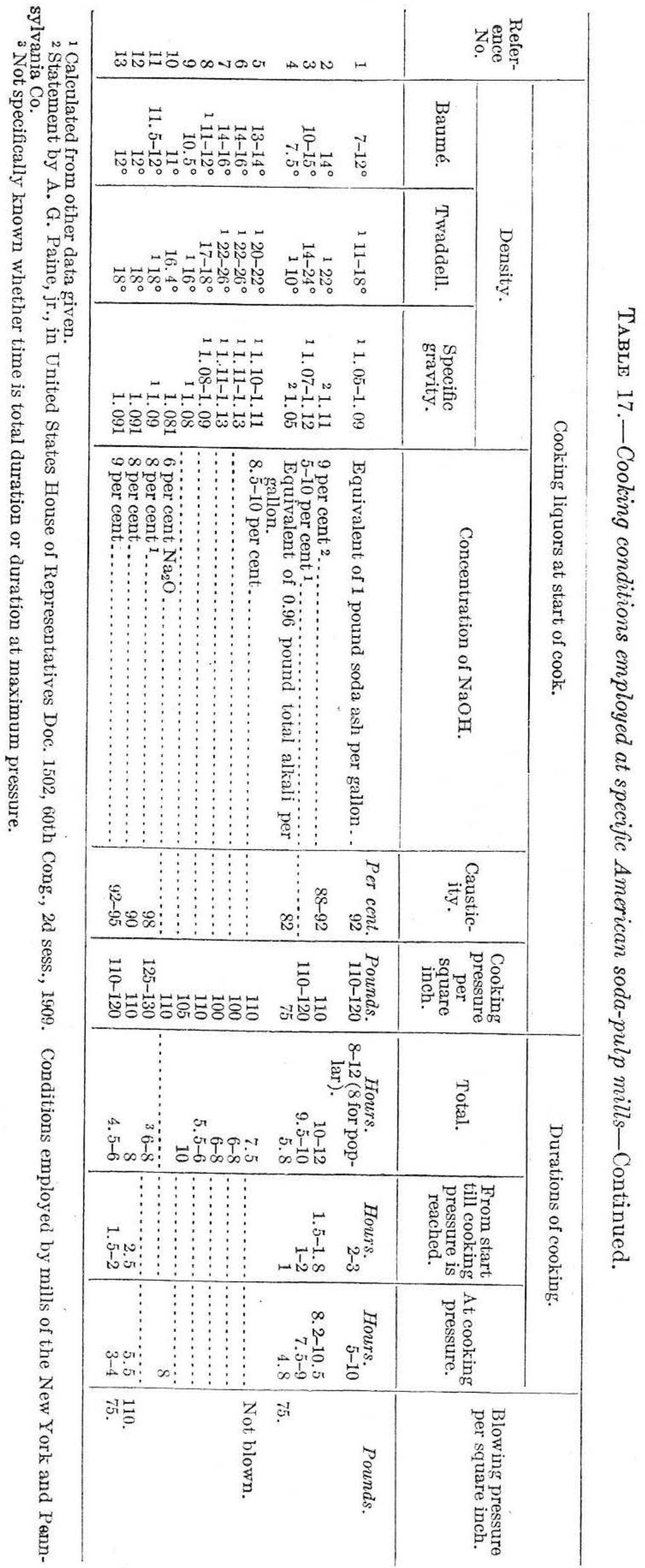




\section{BIBLIOGRAPHY.}

$$
\text { (January, 1913.) }
$$

\section{PROPERTIES OF ASPEN AND ITS USE AS A PULPWOOD.}

Journal of the Society of Chemical Industry. Poplar wood pulp. In: Jr. Soc. Chem. Ind., 24 (1905), 148.

L'Industria della Carta. Poplar and the paper industry. Extract in: Paper $V$ (1911), (5), 13.

Litchauer, Viktor. Die "amerikanische Aspenzellulose." 3 pp., illus. In: Zentrallblatt für die öster.-ungar. Papierindustrie. XXIII (1905), (26), 822-5.

Macmillan, H. R. Forest products of Canada: pulpwood. Bulletins 12 (1908); 26 (1910); 30 (1911), Forestry Branch, Department of Interior, Canada. 9; 14; 17 pp., tables, $8^{\circ}$. Ottawa; Government Printing Bureau, 1909; 1911; 1912.

Papier Fabrikant. Die Pappel (Populus canadensis) als Papierholz. In: Papier Fabrikant, 9 (1911), 199-201.

Sargent, Charles Sprague. Report on the forests of North America. Vol. IX, Reports of the Tenth Census, United States Department of the Interior, Census Office. 612 pp., maps, tables, $4^{\circ}$. Washington: Government Printing Office, 1884.

Svensk Pappers-Tidning. Poplar as a pulpwood in Italy. Swedish translation of an Italian letter. In: Svensk Pappers-Tidning, 12: te årg. (1909), (22), 225-6.

United States-Agriculture, Department of-Forest Service-Bulletins 74 AND 77. Forests products of the United States, 1905; 1906. Wood used for pulp; pulpwood consumption. 6;8 pp., tables, $8^{\circ}$. Washington: Government Printing Office, 1907; 1908.

United States-Commerce and Labor, Department of-Census, Bureau ofForest Products No. 1. Pulpwood consumption: 1907; 1908; 1909; 1910.14 14 12; 15 ; 10 pp., tables, $8^{\circ}$. Washington: Government Printing Office, 1908; 1909; 1911; 1912.

United States-Commerce and Labor, Department of-Census, Bureau of. Paper and wood pulp statistics; preliminary report for 1909 . $6 \mathrm{pp} .$, tables, $8^{\circ}$. Washington, April 26, 1911.

Weigle (W. G.) and Frothingham (E. H.). The aspens: their growth and management. United States Department of Agriculture, Forest Service, Bulletin 93. 35 pp., tables, $8^{\circ}$. Washington: Government Printing Office, 1911.

\section{THE SODA PROCESS OF PULP MAKING.}

Bersch, Joseph. Cellulose, Cellulose-produkte und Kautschuksurrogate. Berlin, 1903. English translation, "Cellulose, cellulose products and artificial rubber" by Wm. T. Braunt. 336 pp., illus., 8 . Philadelphia: H. C. Baird and Co., 1904.

Beveridge, James. Papermaker's pocketbook. 2d ed., 225 pp., illus., tables, $8^{\circ}$. London: McCorquodale and Co., Ltd., 1911.

Clapperton, George. Practical papermaking. $2 \mathrm{~d}$ ed., 226 pp., illus., $8^{\circ}$. London: Croxby, Lockwood and Son, 1907.

Congdon, E. A. The manufacture of chemical fiber. In: School of Mines Quarterly, $X$ (1889), 163-172.

Cross (C. F.) and Bevan (E. J.). Textbook of papermaking. 2d ed., 330 pp., illus., tables, $8^{\circ}$. London: E. \& F. N. Spon, Ltd., 1900.

Cross (C. F.), Bevan (E. J.), and Sindall (R. W.). Woodpulp and its uses. 270 pp., illus., $8^{\circ}$. New York: D. Van Nostrand Co., 1911. 
De Cew, Judson A. The function of the caustic soda process in the production of cellulose from woods. In: Jr. Soc. Chem. Ind., 26 (1907), 561-3; Chemical Abstracts, 1908,319 .

Griffin (R. B.) and Little (A. D.). The chemistry of papermaking. $515 \mathrm{pp.,}$ illus., $8^{\circ}$. New York: Howard Lockwood and Co., 1894.

Hofman, Karl. Praktisches Handbuch der Papier fabrikation. 2d ed., 2 vols., 1800 pp., $4^{\circ}$. Berlin: Papier Zeitung, 1897.

International Library of Technology, Vol. 20, Part 2. Manufacture of paper. 58 pp., illus., tables, $8^{\circ}$. Scranton, Pa.: International Textbook Co., 1902.

Klein, Arthur. The process of manufacturing chemical wood pulp. Proceedings, Verein der Zellstoff- und Papier- Chemiker, Berlin, 1909. Also in: Papier Zeitung, 34, 227, 267: Chemical Abstracts, 1909, 1341.

Leighton, Marshall Ora. Preliminary report on the pollution of Lake Champlain. United States Department of the Interior, Geological Survey, Water Supply and Irrigation Paper No. 121.119 pp., illus., $8^{\circ}$. Washington: Government Printing Office, 1905.

Paine, JR., A. G. Description of the soda process as practiced at the mills of the New York and Pennsylvania Company, 1908. In: Vol. IV (pp. 2628-2633) of Pulp and Paper Investigation Hearings. United States House of Representatives, 60th Congress, 2d sess., Doc. 1502. Washington: Government Printing Office, 1909.

Reid, T. Anderson. Wood as a papermaking material. Tables. In: Jour. Soc. Chem. Ind., 5 (1886), 273-276.

Silcox, George W. Report on the art of printing and on manufactures of paper. With appendix, 30 pp., index, $8^{\circ}$. In: Vol. II, Reports of the Commissioners of the United States to the International Exhibition held at Vienna, 1873. United States Department of State. Washington: Government Printing Office, 1875.

Srndall, R. W. The manufacture of paper. 275 pp., illus., bibl., $8^{\circ}$. New York: D. Van Nostrand Co., 1908.

Sindall, R. W. Paper technology. 2d ed., 270 pp., illus., tables, $8^{\circ}$. London: Chas. Griffin and Co., 1910.

Stevens, Henry P. Paper mill chemist, 280 pp., 67 illus., 82 tables, $8^{\circ}$. London: Scott, Greenwood and Son, 1908.

Sutermeister, Edwin. The soda process for cellulose manufacture; the consumption of caustic soda and its influence on yield and bleaching properties. (Presented at the Eighth International Congress of Applied Chemistry in New York, Sept. 11, 1912.) In: Paper, $I X$ (1912), (12), 15-16.

Watt, Alexander. The art of papermaking. $3 \mathrm{~d}$ ed., $260 \mathrm{pp}$., illus., $8^{\circ}$. London: Crosby, Lockwood and Son, 1907.

EFFECTS OF CAUSTIC SODA AND WATER ON CELLULOSE.

Cross (C. F.) and Bevan (E. J.). Cellulose. 3d ed., 328 pp., plates, diag., tables, 8. New York: Longmans, Green and Co., 1903.

Cross (C. F.) and Bevan (E. J.). Researches on cellulose, 1895-1900, 2d ed., 180 pp., tables, $8^{\circ}$; Researches on cellulose, 1900-1905, 184 pp., $8^{\circ}$; Researches on cellulose, 1905-191.0, 8 . London: Longmans, Green and Co., 1907; 1906; 1912.

Miller, O. Constitution of soda cellulose. In: Berichte, 41, 4297-4304; Chemical Abstracts, 1909, 650 . 
Miller-Moskan. The reaction of cellulose with sodium hydroxide. In: Berichte, 40, 4903-05; Chemical Abstracts, 1908, 1186.

Schwalbe, Carl G. Die Chemie der Cellulose. Bibliographie. 2 Bde., $8^{\circ}$. Berlin, 1910-1912.

Schwalbe, Carl G. The cellulose problem. In: Paper, 2 (1911), (4), 9.

Schwalbe, Carl G., and Robinoff (Michael). Action of vater and alkali upon cotton cellulose. In: Zeitschrift für angew. Chemie, 24, 256-8; Chemical Abstracts, 1911, 1838.

Tauss, H. Verhalten von Holz und Cellulose gegen erhöhte Temperatur und erhöhten Druck bei Gegenwart von Wasser. In: Dingl. polyt. J., 273 (1889), 276285. Abbreviated translation, "The behavior of wood and cellulose at high temperatures in presence of water," in: Jour. Soc. Chem. Ind., 8 (1889), 913.

Tauss, H. Verhalten von Holz und Cellulose gegen erhöhte Temperatur und erhöhten Druck bei Gegenwart von Natronlauge. In: Dingl. polyt. J., 276 (1890), 411-428. Abbreviated translation, "The behavior of wood and cellulose at high temperatures and pressures in presence of caustic soda," in: Jour. Soc. Chem. Ind., 9 (1890), 883.

Viewig, W. The nature of alkali-cellulose, in: Papier Zeitung, 32 (1907), 130-131, 174-175; Chemical Abstracts, 190\%, 1320.

VIEWIG, W. The action of cold caustic soda solutions on cellulose. In: Berichte, 40, 3876-83; Jr. Soc. Chem. Ind., 26 (1907), 1157; Chemical Abstracts, 1908, 178.

Viewig, W. Action of cold caustic soda on cellulose. In: Berichte, 41, 3269-75; Chemical Abstracts, 1908, 3403. 